UCRL-CR-121206

B292103

\author{
Russian Academy of Sciences \\ Joint Institute of Physics of the Earth \\ Complex Seismological Expedition
}

\title{
ESTABLISHMENT OF DATA BASE OF REGIONAL SEISMIC RECORDINGS FROM EARTHQUAKES, CHEMICAL EXPLOSIONS AND NUCLEAR EXPLOSIONS IN THE FORMER SOVIET UNION
}

\author{
N. A. Ermolenko \\ Yu.F. Kopnichev \\ V. G. Kunakov \\ O. K. Kunakova \\ M.Kh. Rakhmatullin \\ I. N. Sokolova \\ Zh. I. Vybornyy
}

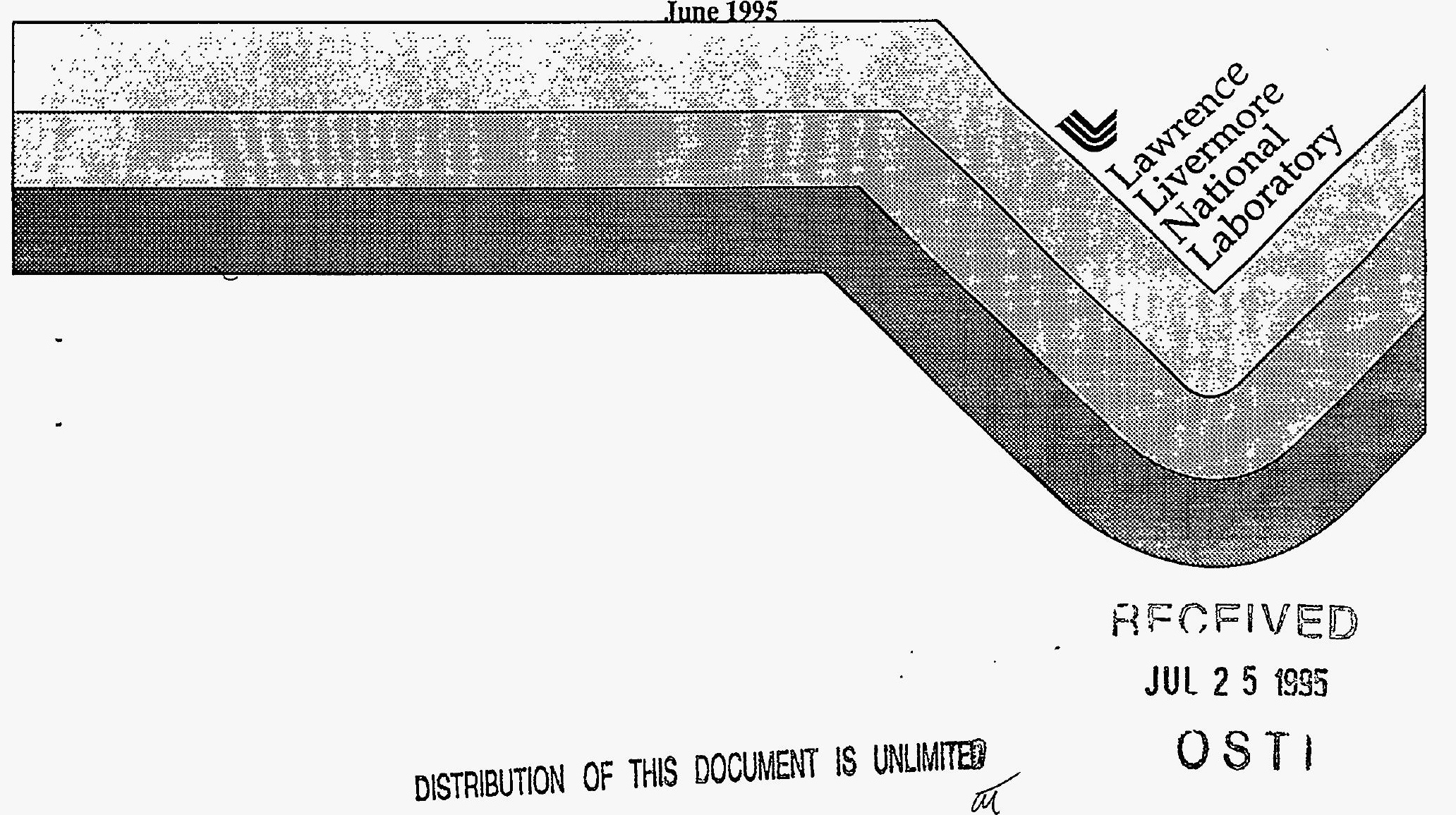




\section{DISCLAIMER}

This document was prepared as an account of work sponsored by an agency of the United States Government. Neither the United States Government nor the University of California nor any of their employees, makes any warranty, express or implied, or assumes any legal liability or responsibility for the accuracy, completeness, or usefulness of any information, apparatus, product, or process disclosed, or represents that its use would not infringe privately owned rights. Reference herein to any specific commercial product, process, or service by trade name, trademark, manufacturer, or otherwise, does not necessarily constitute or imply its endorsement, recommendation, or favoring by the United States Government or the University of California. The views and opinions of authors expressed herein do not necessarily state or reflect those of the United States Government or the University of California, and shall not be used for advertising or product endorsement purposes. 


\section{DISCLAIMER}

Portions of this document may be illegible in electronic image products. Images are produced from the best available original document. 


\title{
PUSSIAN RCBDERI OF SCIENCES
}

SOAT IWTITUTY OR PHYSTS OF THE EAPTH

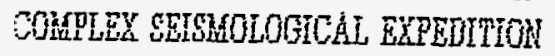

\author{
$R E D R T$
}

ESTABLISHMENT OF DATA BASE OF REGIONAL SEISKIIC

RECORDLLGS FFON EARTHQOAKES, CHEMTCAL EXZLOSTONS AND

NUCLEAR EXPLOSIONS IN THE FORMER SOVIET ONION

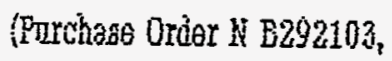

Contract with Lawrence Livermore kational

Saboratory, Univeraity of California, DSA)

Talgor, 1995

MASTER 
INNOTATION.

in this report results of work on establishment of a data base of regional seiamic recordings from earthquakes, chemical explosions and nuolear explosions in the former Soviet unions are desoribed. This work was oarried out in the Complex Seismologioal Expedition (CSE) of the Joint. Institute of Fhysios of the Earth (JIFE) of the Russian Acaderny of Soienoes acoording to an agreement between the JIPE and Lawrence Livermore National Laboratory (University of California, USA).

The recording system, methods of investigations and prinary data processing are described in detail.

The largest number of digital records was received by the permanent seismio station Talgar, situated in the northern Tien Shan, $20 \mathrm{~km}$ to the east of Almaty oity. More than half of the records are seismograms of underground nuclear explosions and chemical explosions. The nuclear explosions were reoorded mainly from the Semipalatinsk test site. In addition, records of the explosions from the Chinese test site Lop Nor and industrial nuclear explosions from the west Siberia region were obtained.

Four reoords of strong chemical explosions were picked out (two of them have been produced at the Semipalatinsk test site and two - in Uzbekistan ). We also obtained 16 records of orustal earthquakes, mainly from the Altai region. close to the Semipalatinsk test site, and also from the west china region. close to the Lop Nor test site. In 
addition, a small number of records of earthquakes and underground nuclear explosions, received by arrays of temporary stations, that have been working in the southern Kazakhstan region are inoluded in this report.

Parameters of the digital seismograms and file struoture are desoribed.

In the end of the report possible directions of future work on the digitizing of an unique data arohive, which bave been acoumilated in the CSE, are discussed. 
CONTENTS

INTRODUCTION. $\ldots \ldots \ldots \ldots \ldots \ldots \ldots \ldots \ldots \ldots \ldots \ldots$

1. APPARATUS, METHODS OF INVESTIGATION AND PRIMAFY

FROCESSING. . . . . . . . . . . . .

1.1. Apparatus used. ..................

1.2. Magnetio Recording System.............11

1.2.1. Magnetic reoording station ASS-6/12.....11

1.2.2. Flayback system VSS- $6 \ldots \ldots \ldots \ldots \ldots \ldots 18$

1.2.3. Seismic information input system AVSI-6..14

1.3. Telemetered station RTS-AN.............17

1.4. Seismio station PUSK-2...............21

1.4.1. Working cycle of the station PUSK-2.....27

1.5. Calibration of the seismic apparatus of the CSE.28

2.OBSERVATION SYSTEVE. ....................29

2.1. Organizing the observation point...........29

2.2. Station and seismio arrays.............29

2.3. Seismic station Talgar................

2.4. System of observations at the gas deposit in the

Muynkum sands...................... 33

2.5. System of observations at the small-aperture array $\ldots \ldots \ldots \ldots \ldots \ldots \ldots \ldots \ldots \ldots \ldots \ldots \ldots \ldots$

2. ARCHIVES OF THE DIGITAL DATA...............

3.1. Digital data obtained by the Talgar station....42

2.1.1. Seismograns recorded by apparatus ASS....42

Q.1.2. Seisnograms recorded by the apparatus

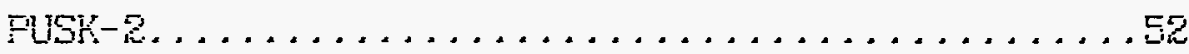


3.2. Seismograms obtained by the station installed in the Muyunkum desert area................ 54 3.8. Seismograms reoorded by the small-eperture

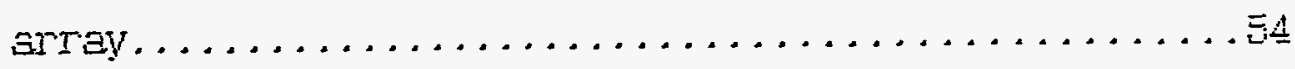
CONCLUSIONS . . . . . . . . . . . . . . . . . . . 105 REFERENCES $\ldots \ldots \ldots \ldots \ldots \ldots \ldots \ldots \ldots \ldots \ldots \ldots \ldots \ldots$ 
INTRODUCTION.

The Talgar subdivision of the complex seismologicai Exredition (CSE) of the Joint Institute of Physios of the Earth (JIPE) of the Russian Academy of Sciences was organized in 1960. The main focus of the CSE work was the study of loogl seismioity, inoluding induced seismioity. investigations of the Earth structure, development of methods for detailed seismio zoning and mineral prospecting. study of the nature of seismic wave fields, and finally, the monitoring of nuclear explosions.

Special networks of seismio stations were installed to carry out this geophysical research. The most important results were obtained during the monitoring of the underground nuclear explosions that occured in the CSE since 1969. Until 1991 the CSE installed more than one hundred highiy-sensitive seismic stations in various regions of the former Soviet Union. These stations were set up as part of a speciai project to identify uniquely sensitive locations for the monitoring nuclear explosions. Most of these were temporary stations - not part of the regular national seismio network. Most of these stations consisted of 1 E-component short-period set from 1 to $10 \mathrm{~Hz}$ and 1 vertical high-magnification channel centered at $1 \mathrm{he}$. Narrow-band channels had very high gain - in some cases more than 1 million. Reoording was usually with a pen-ink system. Most 
stations operated for 1 to 2 years.

In the CSE an apparatus of magnetic recording (analog. and digital) was also used, although to a much smaller extent. Also, investigations with temporary small-aperture arrays have been carried out in some regions.

Because of the use of highly sensitive seismio stations a huge amount of experimental material has been acoumulated. allowing the solution of various geophysical problens.

It is necessary to note that the seismograms are kept. in Talgar in an analog form - either on photographic and usual paper, or on magnetio tapes. Due to this there is an urgent need to preserve this material and convert it to a digital form. For this reason Lawrence Livermore National Laboratory (University of California, USA) concluded this contract with the JIFE.

A major goal of this work is the establishment of a data base of regional seismic recordings from earthquakes, chemical, and nuclear explosions in the former Soviet Union.

This report details the results of the work to convert. into digital form a relatively small part of the seismogram archives of the CSE, which have been kept on magnetio tapes.

The report consists of an introduction, 3 main parts, and conclusions. In the first part of the report we describe the apparatus used. In the second part we consider observation systems, including the seismio station Talgar, from which the largest volume of data has been obtained, and also small seismic arrays, which have been installed in southern Kazakhstan. The third part is devoted to $a$ 
description of the digital data archives, which are appended to this report.

Floppy-disks which contain the text of the report in English and digital seismograms are inoluded with the report.

The report is 108 pages, includirg 40 pages of text, E7 figures and 11 tables.

The following CSE emplovees took part in this work:

Kopnichev Yu.F.-professor and director of the CSE.

Kuriakov V.G.- senior soientist.

Rakhmatuli in M.Kh.-leading scientist.

Sokolova I.N.-junior scientist.

Vybornyy Zh. I.-engineer.

Ermolenko N.A.-engineer.

Kunakova O.K.-engineer.

Zhernokleva I.A., Linnik V.V. and Starchenko S.G. took. part in the production of this report. 
1. APPARATUS, METHODS OF INVESTIGATION AND PRIMARY PROCESSING.

In this report results of the work on the creation of the digital data base, obtained by a magnetio recording. system are described. Below we will consider mainly the data recorded by the Talgar station, which is located in the northern Tien Shan region $20 \mathrm{~km}$ to the east of Alnaty city, and also a small volume of data recorded by arrays of ternoorary stations that have been installed in the Muyunkum desert and in the $11 i$ river area (both - in southern Kazakhstan, see Fig.1.1).

\subsection{Apparatus used.}

Recording of the seismic data, presented in this report, has been carried out by the following standart sets of devioes:

1) By apparatus consisting of stations of the magnetio recording system ASS-6/12 or ASS-3/12, playback systern VSS-6 and seismio information inout system AVSI, or playback system VSS-3/6.

2) By the set of telemetered stations RTSS, consisting of 12 field units, sending the information through radiochannels or wires, and recording center on magnetio tapes (stations ASS-E/12). 


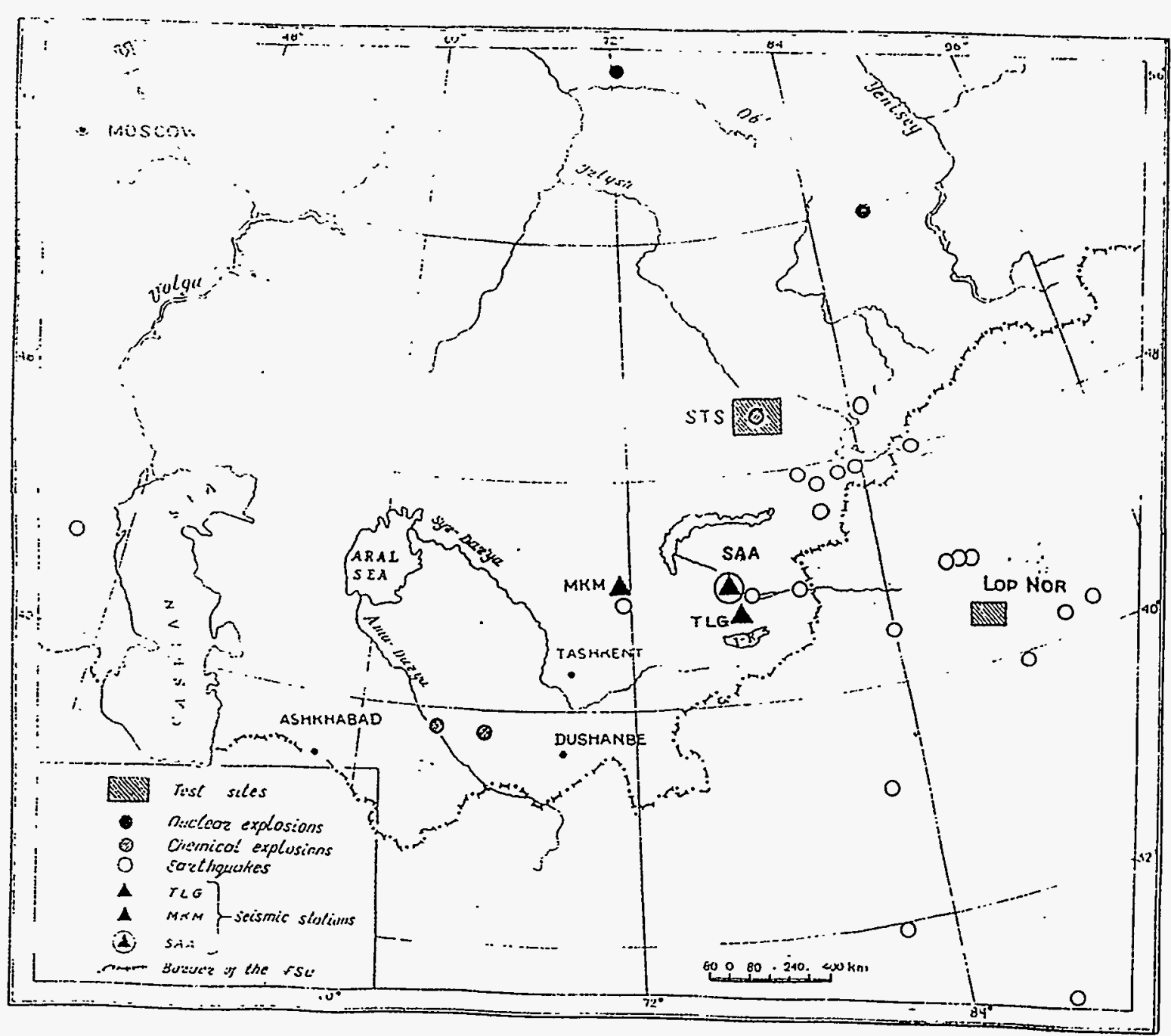

Fig. 1.1. Location of the stations, epicenters of underground nuclear explosions, chemical explosions and earthquales. 
Our experience with this work has shown that these stations have technical parameters that are stable in time, easy to use and mobile and reliabie in operating. This allows quick installation of seismio arrays and obtaining high-quality digital records when carrying out the field observations.

3) By the software operated seismio system PUSK-2, functioning in a triggered regine. An original algorithm of the information receiving is used in this set, which allows the dynamio range of the signals recorded to be enlarged considerably.

Below the main characteristics of the devices used are described.

\subsection{Magnetic Fecording System.}

\subsubsection{Magnetio recording station ASS-6/12.}

The automated seismio station ASS-6/12 [Brulev et al, $1980]$ is intended for long-term permanent recording the seismio information together with time code on inagnetic tape. The mode of information reoording is a direot analog. reoord with a high-frequency bias. The usual number of channels of the magnetio record is 16 . The station permits two regimes of the recording: for 5 seismic channels (when recording at two amplitude levels, which gives a dynamio range of $70 \mathrm{dE}$ ) or for 12 channels (when recording at $a$ dynamic range of $40 \mathrm{~dB}$ ). The station allows recording at one 
of three speeds of tape movernent: $0.5,1$ and $2 \mathrm{~mm} / \mathrm{sec}$, which permits a frequenoy range of the seismic channels (0.5-16) Hz. (0.5-32) Hz and (0.5-64) Hz respectively. Fower is provided by $12 \mathrm{~V}$ rechargable batteries.

The station consists of a tape recorder unit, an amolifier unit, a control unit and seismometers. The amplifier unit includes 12 idenfical amplifiers for the seismic reoord and an attenustion circuit for the ingut signal and a choice of a recording regime (if necessary). The magnetio tape recorder unit includes the tape drive mechanism, quartz clocks, a former of the bias signal and a calibration oscillator ( $2 \mathrm{~Hz}$ sinusoidal signal, which is fed three times a day into the auxiliary coils of the seismometers). The control unit, intended for real-time verification of the station operation, consists of a reference quartz olook, a control circuit and direction of the olooks of the reoording station and a oircuit of the verification of the seismio and aluiliary channel operation. Note that the reference quartz olocks are started by timing signals and allows estimation of the accuracy of the quartz olooks at the recording station to within 0.001 seo.

Each recording station includes SM-3 (three-component) seismometers with a natural period of 2.0 sec.

During station operation, seismic signals from the seismometers go to amplifiers inputs through the attenuator. From the amplifier output, signals go to the 12 magnetio heads of the magnetio reoording unit in such a manner that seismic signals of one amplitude level or signals from 
channels from 1 to 6 (in the regime of 12-channel recording) are recorded using one unit. The seimio signals of a second ampitude level or signals from channels $r$ to 12 (in the regime of 12 -channel recoriing) are recorded using the 6 magnetio heads of the seoond unit. The time code and reference irequenoy are recorded on the last 4 channels of the head unit.

\subsubsection{Flaybook system VSS-6.}

The VSS-6 system is the laboratory part of the instrument set. It is intended for transformation of the information recorded on the magnetio tapes by the $A 5 S-6 / 12$ stations into osoillograns (on photographic paper) or into the digital form using the AVSI-6 device.

The playback system includes a tape-recorder, a processing rack, and a light-based oscillograph. During playback the signals recorded on the tape with one of the magnetic head units ( 6 seismic and 2 auxiliary channels) are reproduced simultaneously. Thus, station VSS-6 carries out. the suocessive signal reproduction: first one amolitude level, then the other or irst channels 1 to 6 , then 7 to 12. when operating in the 12-channel recording regime. seismio signals selected in such a manner go from the tape recorder to inputs of six amplifiers at the processing rack. From the amplifier outputs for each of the signals are branohed to the inputs of three filters of upper and lower frequenoies and one final amplifier. The last oirouit forms 
a broad-band (without filtering) channel. From the filter, output signals also go to the final amplifiers and later to galvanometers of the osoillograph for recording on photographio paper. From the final amplifiers the signals aiso go to inputs of an analog-to-digital converter (DTD) of the apparatus AVSI-6. It is possible to obtain seismic information from the output of the VSS-6 device either in broad-band, or after filtering.

Signals of timing frequenoy (10 $\mathrm{khz}$ ) are also obtained from the processing rack. A divisor of the timing frequency (to $2,4,8$ and 16 times) is part of in circuit. This ensures a choice of an optimal sampling frequency. The next modification of the playback system VSS-3/6 has such the characteristios. Through amplitude-frequenoy characteristios of the signals presented are shown in Fig. 1.2. Curve 1 corresponds to the signals of the ASS in the period of $1982-1984$, and curve 2 , to the signals in the period of $1986-1988$.

1.2.3. Seismio information input systern AVSI-6.

The seismic information input system AVSI-6 is intended for transformation of information coming from the station VSS-6 into digital form in ES format and for recording of the digital signal on a standard magnetio tape storage (NM) in automated regine. The AVSI-8 systern consists of an analog-to-digital converter (UTP) and data-formating device UFIN-1024 for recording on the MM. When reproducing the 


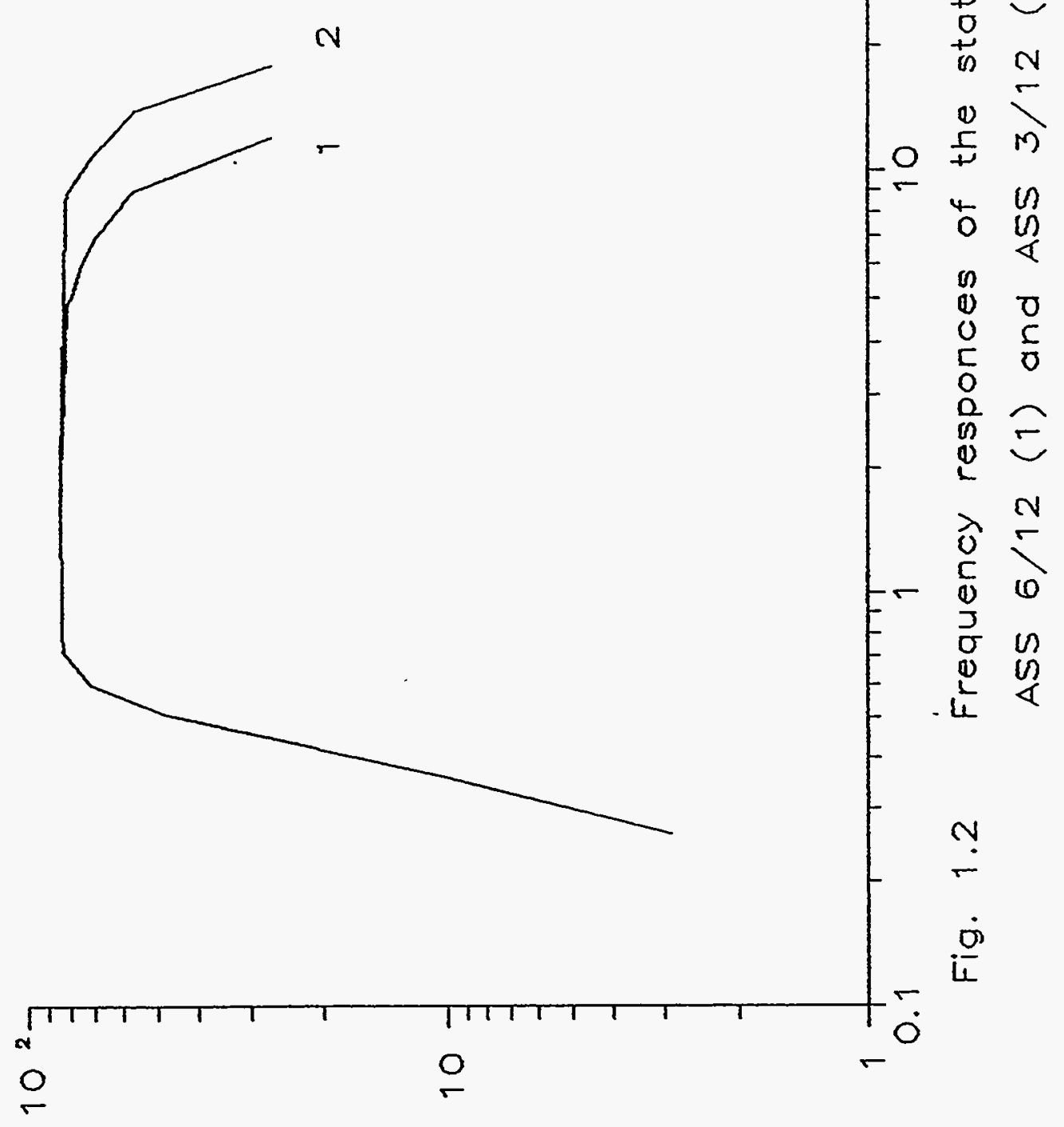


seismio information an analog-digital signal transformation up to 9 ranks for 6 channels is carried out. The result of the transformation, together with auiliary information, is stored in the memory of the UTP. To contral the conversion the data are read from an operative memory device (OzU).

The data are then transformed into anslog form and can be seen on an oscilloscope soreen. The system receives the information stored in the menory and sends it to the device UFIN-10RA through an interface line. Here 1 kbyte segments with byte word length are formed; the seismic information is then recorded in the MML. The auxiliary information is recorded by a separate segment with 1 kbyte length. The OZu permits recording and reading of 8 kbytes of 2 -byte numbers for each channel.

Special attention was paid to the quality of the digital data. When recording on the NML the time code information is written to the least-significant bit of the most significant byte. In subsequent computer processing an analysis of this time code is carried out and also the stability of the reference-frequenoy and the acouracy of the start time of the digital record can be estimated.

The structure of an archived digital tape created with the AVSI-6 system is described below.

For processing convenience an 80-bytes segment in ASCII format is written at the beginning of the each file. Information is input from a keyboard of the device UFIN-1024; it inoludes data on a position of switches "attenuation" of the playback system VSS-6, data from 
earthouake catalogs, some auxiliary information. After this 1-Kbyte segment from OZU UTP, including data on the time of the beginning of the digitization(year, month, day, hour, minute, second), and also information on the data recording rate and playback, the sampling frequenoy and on which channels $(1-6$ or $7-12)$ were recorded.

The digital signal is recorded successively in 1-Kbyte segments (6 seismic channels and 8 kbytes numbers for the each channel). Each file is ended by EOF. Later the digital records are introduced into the IBM PC (through the computer ES-1040). Fart of the information was digitized on the device VSS-3/6, which is a modified version of the complex VSS-6-AVSI. At the station VSS-2/6 the records after digitization are input directly to the IBM PC.

\subsection{Telemetered station RTS-AN.}

Telemetered system RTS-AN [Radiotelemetric.... 1990] is intended for continuous recording seismic data. The system consists of two parts: twelve 3-component field units and $\mathrm{a}$ central recording station (CRP). Communication between the field units and the central station is accomplished through radiocharnels operating in the UHF - range, or through wires at short distances. The information is gathered in analog. form permanently on the magnetio tape (standard tape recorders of the A.SS-6/12 system).

Thus, in this case the seismic data is quite similar to the records obtained by the ASS system. 
The following are the general technical characteristics of the RTS-AN system:

1. Number of field points (FP) $\ldots \ldots \ldots \ldots \ldots \ldots \ldots \ldots$

2. Mode of the seismio information transtormation frequency modulation (FM).

3. Mode of radio-telemetry transmission.........FM-FM

4. Number of radiochanneis transmitted from each FP to $\mathrm{GRP} . \ldots \ldots \ldots \ldots \ldots \ldots \ldots \ldots \ldots \ldots \ldots \ldots \ldots \ldots \ldots \ldots$

5. Number of seismic onannels at each FP.........

6. Number of seismic channeis of CEp system.......36

7 . Wode of the data collection - continuously in analog form on magnetic tape by ASS-6/12 recorders.

8. Speed of the magnetio tape drive........

9. Dynarnic range of the seismic channels: without magnetio recording......... at least $54 \mathrm{~dB}$ with magnetio recording.......... at least $\Delta e^{\circ} \mathrm{dB}$

10. Noise level at input ...... not more than $1 \mu \mathrm{V}$

11. Frequency range of the seismic channels at the $1 \mathrm{~dB}$ level..................5. $32 \mathrm{~Hz}$

12. Range of operating temperature FP..... $-30^{\circ} \pm 50^{\circ} \mathrm{C}$

13. For tining reference clocks, mounted in the inagnetic recorder units of the ASS-6/12 system are used.

14. Timing error for 10 days is not more than 100 mseo.

15. Fower, consuned by device FP without transmitter............ less than $1.2 W$, with transmitter............... less than $2.0 \mathrm{~W}$,

1E. Data recorded can be reproduced either on 
oscillograph, or in digital form. For this purpose the playbaok system VSS-6 is used.

A funotional circuit of the RTS-AN system is shown in FiE. 1.3. A field point (FP) includes one or three $\mathrm{SM}-3$ seismometers (1), whose output signais go to amplifiers (2). The amplified signals are modulated in frequenoy by the carrier frequency generators (3). Carrier frequencies are set at $1550 \mathrm{~Hz}, 23 \mathrm{~Hz}$, and $3100 \mathrm{hz}$. Later signals of carrier frequencies are multiplexed by an arithmetic sumation circuit(4). From the output of the sumnation circuit the signal goes to the low-frequenoy input of the transmitter (5). There is an automatic calibration unit in the field system (6). This unit sends a calibration signal into the auxiliary coil of the seismometer, once each eight hours.

The field unit can be also connected with the central recording point by wire line.

The central recording point is intended for continuous receiving of data from the field units, which is transformed into a seismic signal and recorded on magnetic tape.

The signals from the field units, received either by a receiver unit ( () or through a wire line, go to a disoriminator unit (8). In this unit (8) seismio signals are separated, which are then recorded by the ASS-6/12 recording system (9) on magnetic tape.

The time "tag" of the information, recorded on the magnetic tape, is obtained from by the reference clooks (10), which are forming the time code and the reference 


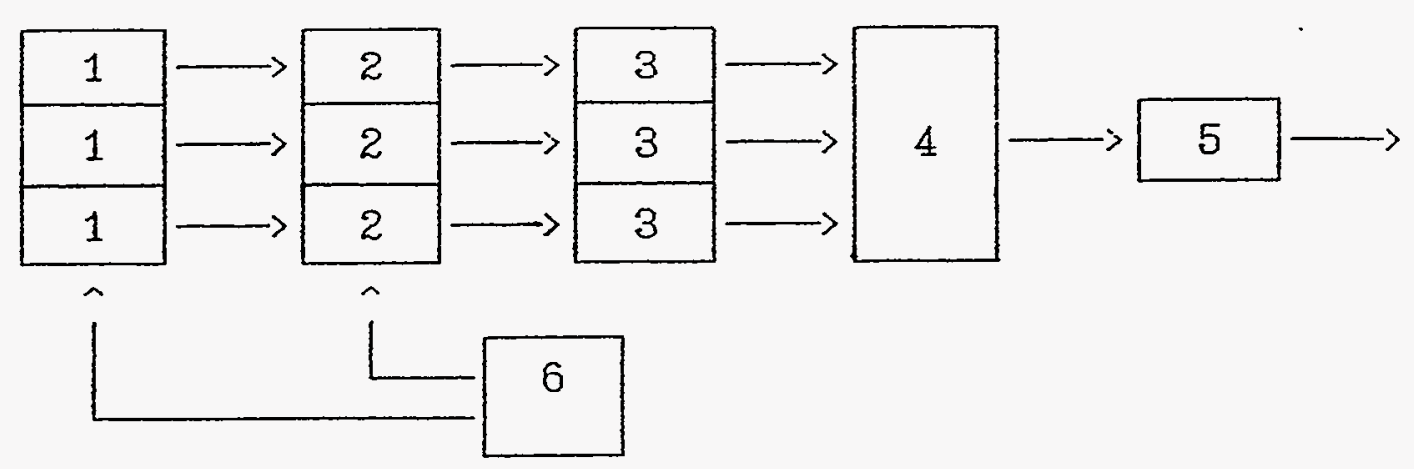

Remote Unit.

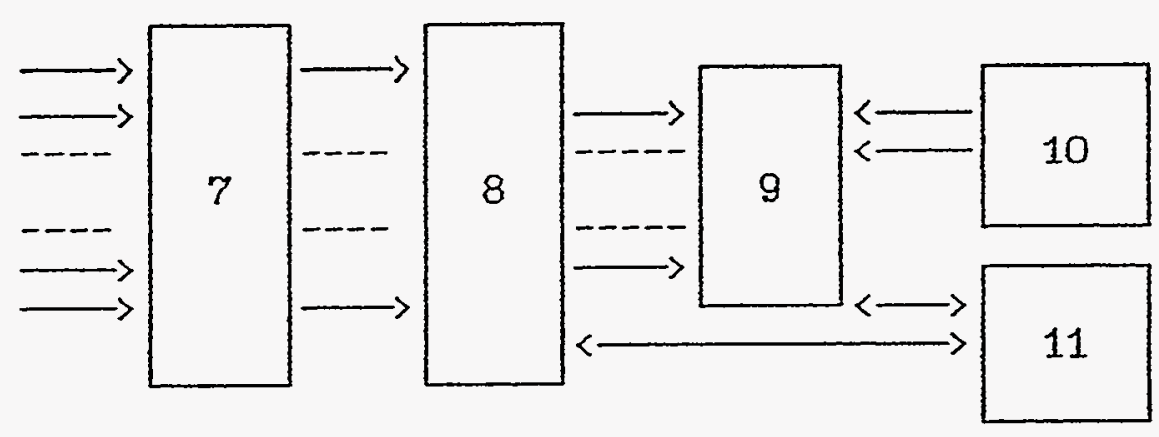

Data collection center.

1. Seismometers, 2. Amplifiers, 3. Modulators, 4. Summator, 5. Transmitter, 6. Calibrator, 7 . Receivers unit, 8. Discriminators unit, 9. Tape recorders, 10. Master clock, 11. Control unit.

Fig. 1.3 Circuit function of the RTS-AN. 
Îrequency.

These signals are recorded on the magnetio tape simultaneously with recording the seismio signals.

Control and reguiation of groups of the central recording point is carrieu out with a control unit (i1).

As the radiochannels the FSS1.2-01 receiver and transmitter FSS 4.1 were used.

The general specifications of devices are as follows:

RECEIVER:

Sensitivity:..................... Unstability of the frequency responce........ $1.5 \mathrm{dE}$ Typical current.................... $2.0 \mathrm{~mA}$ TRANSMITTER:

output power....................... $0.4 \mathrm{w}$ Coefficient of nonlinear distortion.......... $3.0 \%$ Deviation of frequency................ $4 \mathrm{kiz}$ Typical current.....................120 mA Voltage of radiochannels................ $12 \mathrm{~V}$

\subsection{Seismio station PUSK-2.}

The program-controlled complex PUSK-2 is intended for measurement and recording of seisinic and other geophysioai signals in digital form over a broad dynamic and frequenoy range [Aranovich et al. $198 \%$ ]. 
The general technical specifications of the system:

1) The number of connected seismic channels........

2) Frequenoy range af attenuated

input signals: Hz..................1-10

A block diagram of generai units of complex PUGK- $\bar{k}$ is showi in Fig.1.4.

The blook diagram consists of:

computer "Electronica-60" (s)?

rnagnetio tape storage - 5M5800.01 $(9,9)$;

three S-5-S seismographs with high-resistance coil (2);

three am-3 seismographs with high-resistance coil (1);

two units forming the characteristics, BFHD.01 and BFHD. O2 $(3,4)$;

an oscillograph measurement unit UZI-1 $(5,10)$.

Three short-period channels with a bandwidth of $0.5-10$ $\mathrm{Hz}$ (Fig.1.5) are used with the SM-3 seismometer, whereas three intermediate-period channels with bandwidth of $0.1-10$ $\mathrm{Hz}$ (Fig.1.6.) are used with the S-5-S seismometer and unit BFHD.02. Both represent the velocity response. The PUSK-2 system operated in a triggered mode. The unit UZI IDigital device ...1986I (before the beginning of the event) receives and converts continuous signals of microseismic noise, but it does not output the digital data to the PC. The data obtained are continuously analyzed. Depending on the input signal amplitude, the PC determines the coefficient of anolification of the UZI-1; this coefficient is multiplied by a number, given simultaneously by AZF and the result received is written to the core memory iNegrebetzkiy: 


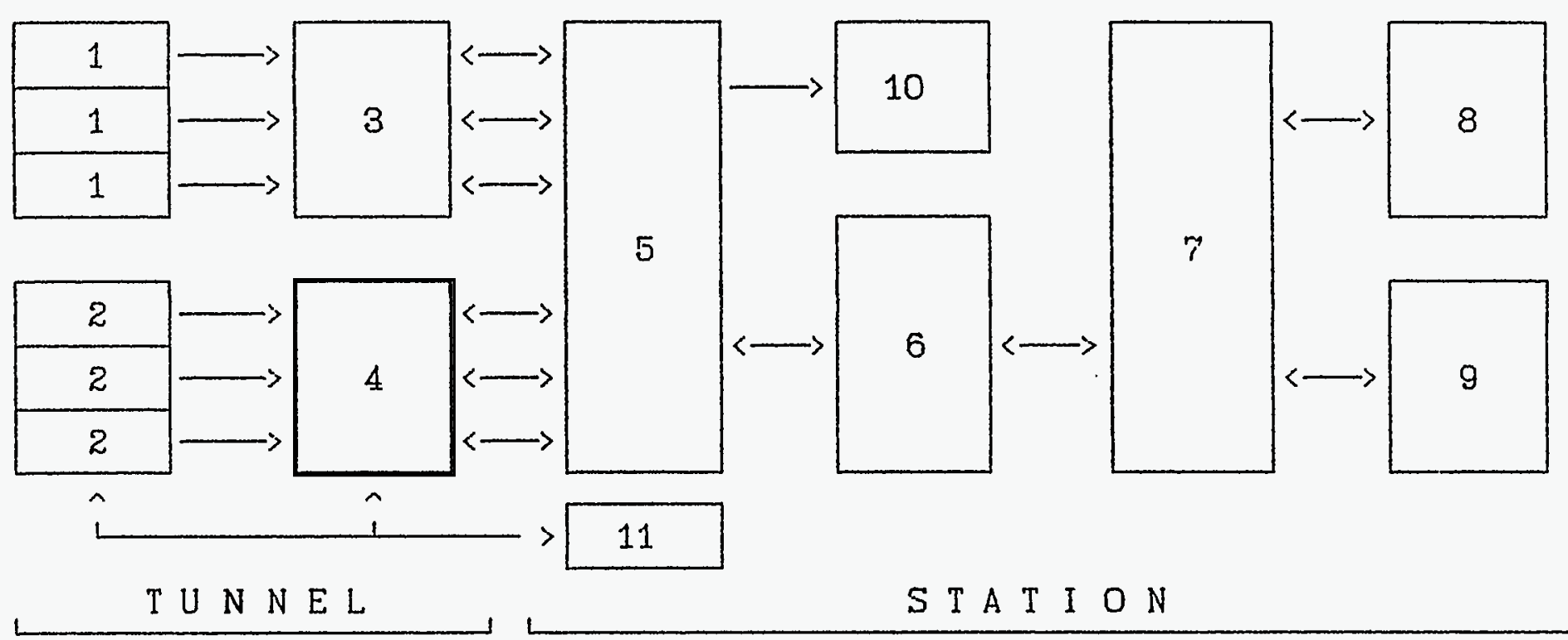

1. Seismometers SM-3 (short-period), 2. Seismometers $5-5-5$ (middle-period), 3. Filter $0.5-10 \mathrm{~Hz}$, 4. Filter $0.1-10 \mathrm{~Hz}$, 5. MUX + A/D converter,

6. Computer (PC), ?. Controller, 8. Tape recorder 1, 9. Tape recorder 2 , 10. Pen recorder, 11. Calibrator unit.

Fig. 1.4 Circuit function of the PUSK-2. 


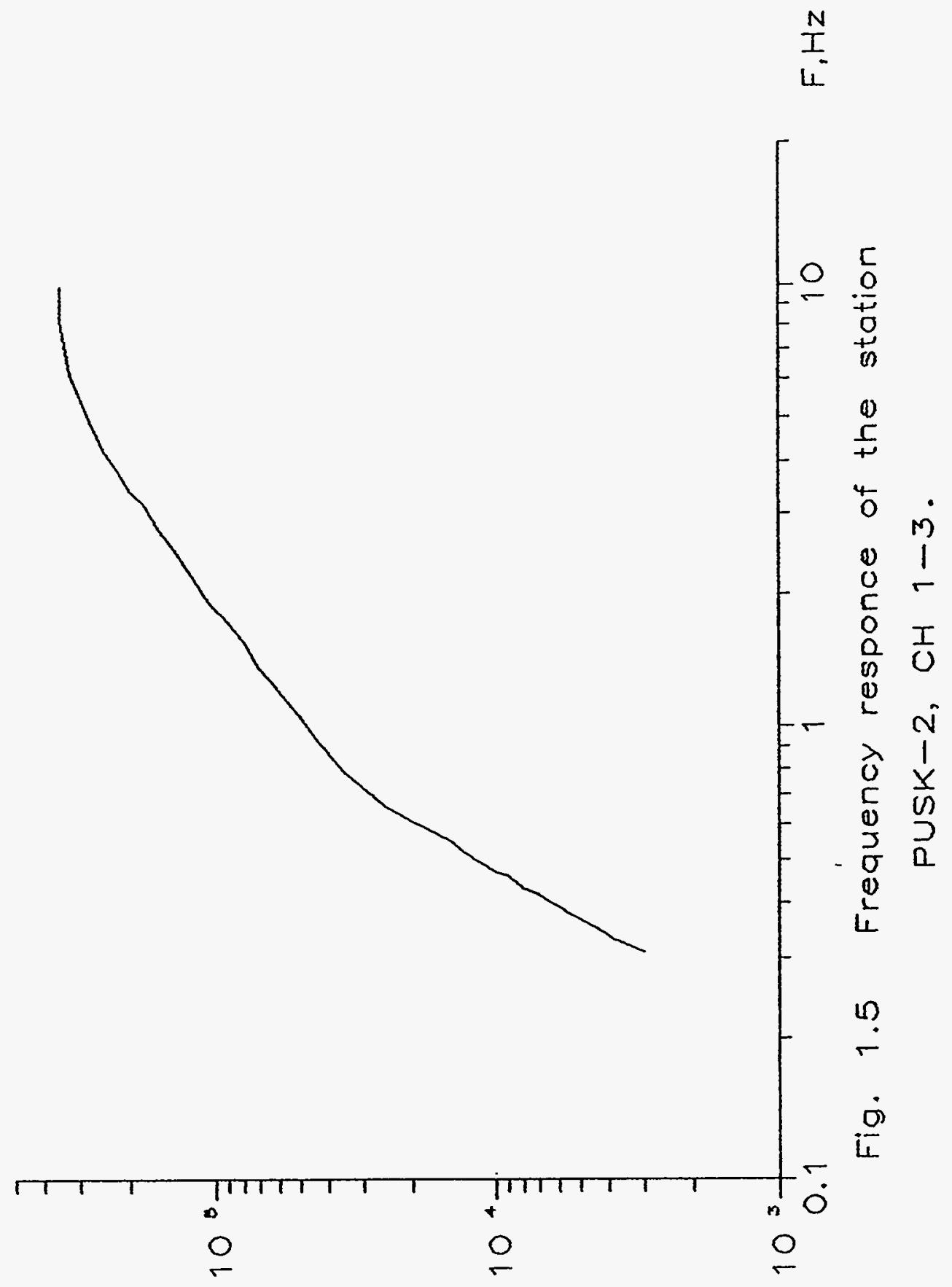




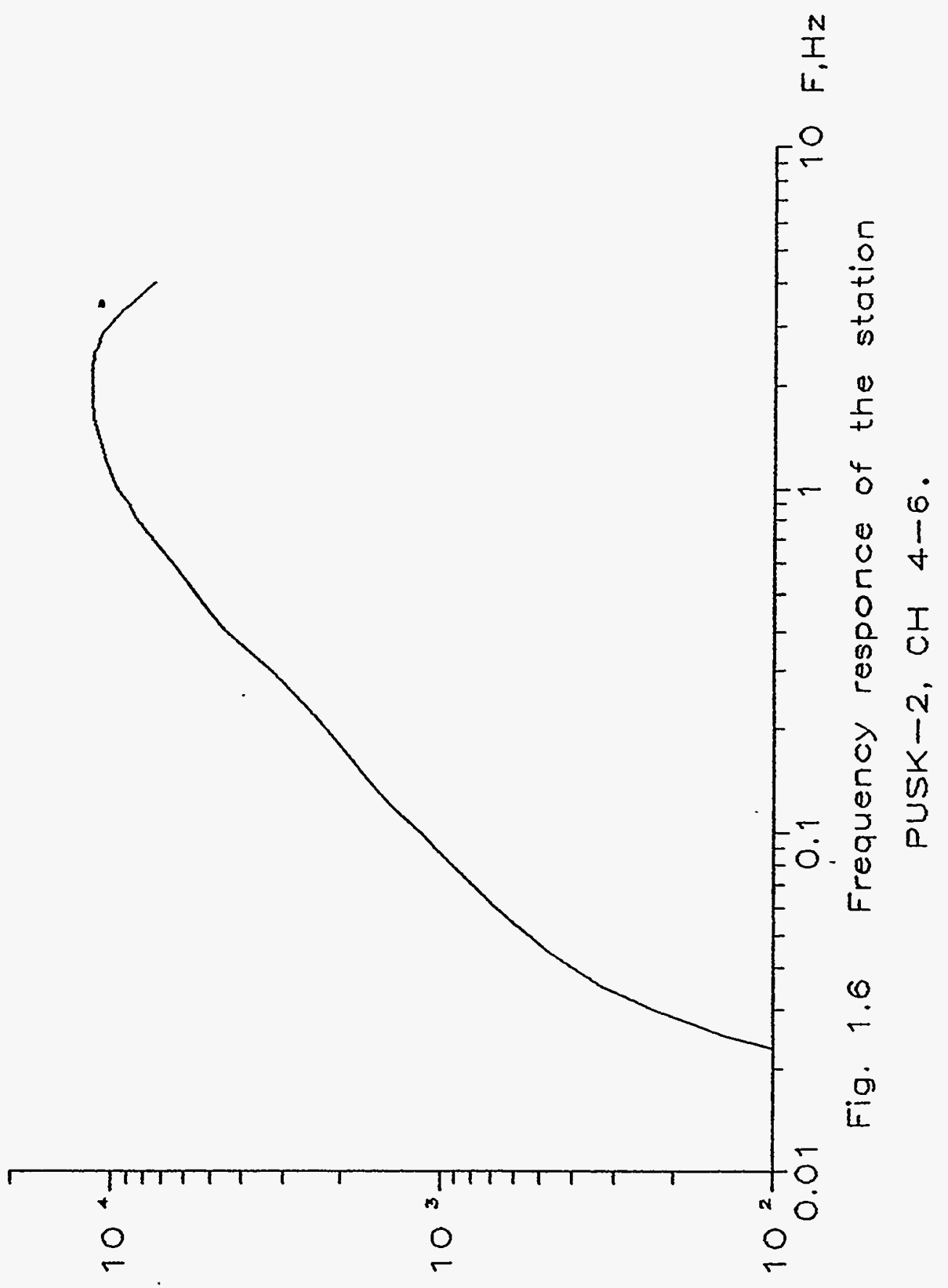


Turetzkiy....1980]. Four different coefficients of anplification oan be used for each station: $1 / 16,1,16$, and 256.

Note that this algorithrn operates independently from the existence of a seismic event. The information is delivered into a FC, and subsequently reoorded on the $\mathrm{NM}$, when the signal energy exoeds a certain velocity. For this purpose a circuit is applied which raises the value of the input voltage to the second power: at a frequenoy of $1 \mathrm{hz}$ for detection of distant events and at frequency of $10 \mathrm{~Hz}$ for local events. The voltage at the output of an electromagnetic seismometer ffor exampie, SM-3-BVY and S5E-EVX), is proportional to the velocity of ground movement. If this voltage value is raised to the second power, the resulting voltage will be proportional to the acceleration of the ground. In the device FUSK-2 the principle described above is used for detection of seismic signals. In the signal detector circuit the measures are provided for protection from a false trigger due to electrical impuises.

Transformation of the seismio signal into digital form is carried out using a maximum sampling frequency of $100 \mathrm{~Hz}$ per channel. For time synhronization of the seismio data an internal timing systern is built into the unit UZI-1. For a control of the whole path of the digital transtornation an output of an analog signal to the recording systern RVZ-3 is provided (after reconstruoting it from the digital code). Caibration pulses can be automaticaily sent to the 
seismometer coil. The polarity of the calibration impulse can be switched by hand.

Parameters of the calibration pulses :

Amplitude - $10 \pm 0.5 \mathrm{~V}$

Duration - $5 \pm 0.15$ mseo

Files containing information on the calibration results have special marks.

Time of the signal transformation -1 mseo.

1.4.1. Working oycle of the station PUSK-2.

During the work the PUSK- $z$ system is in waiting regime and the vertical component of mioroseismio noise is continuosly analyzed and transferred to the input of the system from vertical channel (channels 1,4), until the impulse signal that turns on the recording system is activated.

As soon as the required command impulse is given, the UTI-1 unit organizes the data output to a micro-PC channel and then to the record on magnetic tape.

Event recording takes place on variable-length files. The file size depends on the magnitude and duration of the event. When starting from the first (short-period) channel, the record duration is $5-7$ minutes, from the fourth (intermediate-period) channel, 15 minutes or more.

The current information goes into the operative memory with the old data being continuosly replaced by the new. The 
menory capacity is $20-23 \mathrm{sec}$, which allows about $15-17 \mathrm{sec}$ of pre-event recording.

when the system turned on to record, the NML, whinh is in a regime of the oontrol from the FG, records the event file with a time mark indicating the date and time of the event. After the reoording is finished, the system returns to the waiting regime.

1.E. Calibration of the seismio apparatus of the CSE.

Practical experience with the magnetic recording stations under field conditions had show a necessity to continuousiy control the condition of the seismic channels. A few such methods of control exist: for example, sending a signal of constant amplitude (MGPA) or sinusoidai signals, from a signal generator and also various calibration pulses to $a$ seimometer coil. The pulse calibration is the preferable one, because besides determining the amplitude-frequenoy characteristios it allows determination of the phase-frequenoy characteristios as well, which is necessary for acourate correction of the seismic records. In the CSE all types of calibration are used, depending on the seismometer type.

For example, the PUSK-2 system is oalibrated by a delta-impulse, recording system by shake-tables and also using short puises; and photo- and pen-irk recording systems are controlled by signals of the constant amplitude signal generator (MGEA). 
2. OBSERVATION SYSTEMS.

2.1. organizing the observation points.

The observation points were equipped taking into acoount the existing experience. At the Talgar seisnic station, the seismometers were installed on a conoret pedestal in especially prepared places in a tunnel. In field areas the seismometers were installed mainly on bedrock, in small holes with a tubbing arrangement. The bottom of a hole was fixed with a small volume of cement for better contact. of the seismometer's base with the ground. After installation the hole was filled with soil, which provided a necessary stable temperature regime and protection from wind noise.

Seismometer installation was carried out using a compass orienting the three-component device along the cardinal directions. A seismometer period was established with a stop-watch. Horizontality was checked with a level. The field telemetry site or magnetic recorder with batteries were installed 10-15 meters from the seismometers, together with the antenna.

\subsection{Station and seismic arrays.}

The data base was oreated mainly using data received at the Talgar seismic station. In addition, seismograns obtained at a station installed in the area of the 
"Amangel "dy" gas deposit in the Muynkum desert in 1984 and by the small-aperture array in the area of the Ili river in 1987 (both in southern Kazakhstan) were digitized.

Seismic data recording was carried out by the ASS-6/12 magnetic recording system; these arrays have operated for periods of $1-2$ montis.

\subsection{Seismic station Talgar.}

The station is situated in $7 \mathrm{~km}$ to the south from the oity of Talgar in the foothills of Zailiyskiy Alatau ridge (Fig.1.1). The station coordinates are $43.23^{\circ} \mathrm{N}, \quad r 3.22^{\circ} \mathrm{E}$. The seismometers are installed in a 120-meter-long tunnel, driven directly into the Paleozoic-age orystalline rocks, which are exposed at the surface. The altitude is about 1200 meters above the sea level.

The station is removed from various artificial sources of microseismic noise, thus conditions for seismic observations are rather favourable here. The only shortcoming is the proximity of the Talgar River, which slight.ly lowers a sensitivity of the station.

The Talgar station has operated since 1961 and during this time has carryied out continuous monitoring of seismicity. The station is a regional one; it is equipped with a whole set seismic recording systems. Until 1991 the station took part in the Real-time Service, in the Service of Urgert Reports (in the fomer USCR). At present urgent reports are not sent. 
Initially the station was equipped with one 100 meter-long tunnel (Fig.2.1.). The tunnel has 8 laterai offshoots, in which seismometers have been installed on especially equipped piers.

The construction of the tunnel was completed using a special technology that minimized the breakage of the surrounding bedrock. The tunnel is oriented in the $\mathrm{N}-\mathrm{S}$ direction.

From $197 \mathrm{~g}$ through 1980 a large volume of work on a reconstruction and modernization of the station has been carried out. As a result a new laboratory building and tunnel have been constructed (Fig.2.1), cable lines have been completely replaced, and the recording system has been considerably renewed. In the new tunnel geophysical observation systerns have been installed. Since 1980 two new strainmeters with different modes of signal transtormation have been working including both capacitive and inductive devices as well as an osoillographio recorder. The strainmeters are oriented in direotions $\mathrm{SW}-\mathrm{NE}$, and $\mathrm{SE}-\mathrm{NW}$. In separately equipped compartments 3 -meter-long bending strainmeters with an inductive transformer are installed. Since 1985 an apparatus for radon emission recording with a measurement frequenoy 2 times per a day have been working. It is worth noting that at the Talgar station practioally all new developments of the Special design office of the JIPE RAS, inoluding geophysical apparatus, strainneters. gravimeters, and tiltmeters have been tested in field conditions. Thus: the seismio station Talgar is one of the 


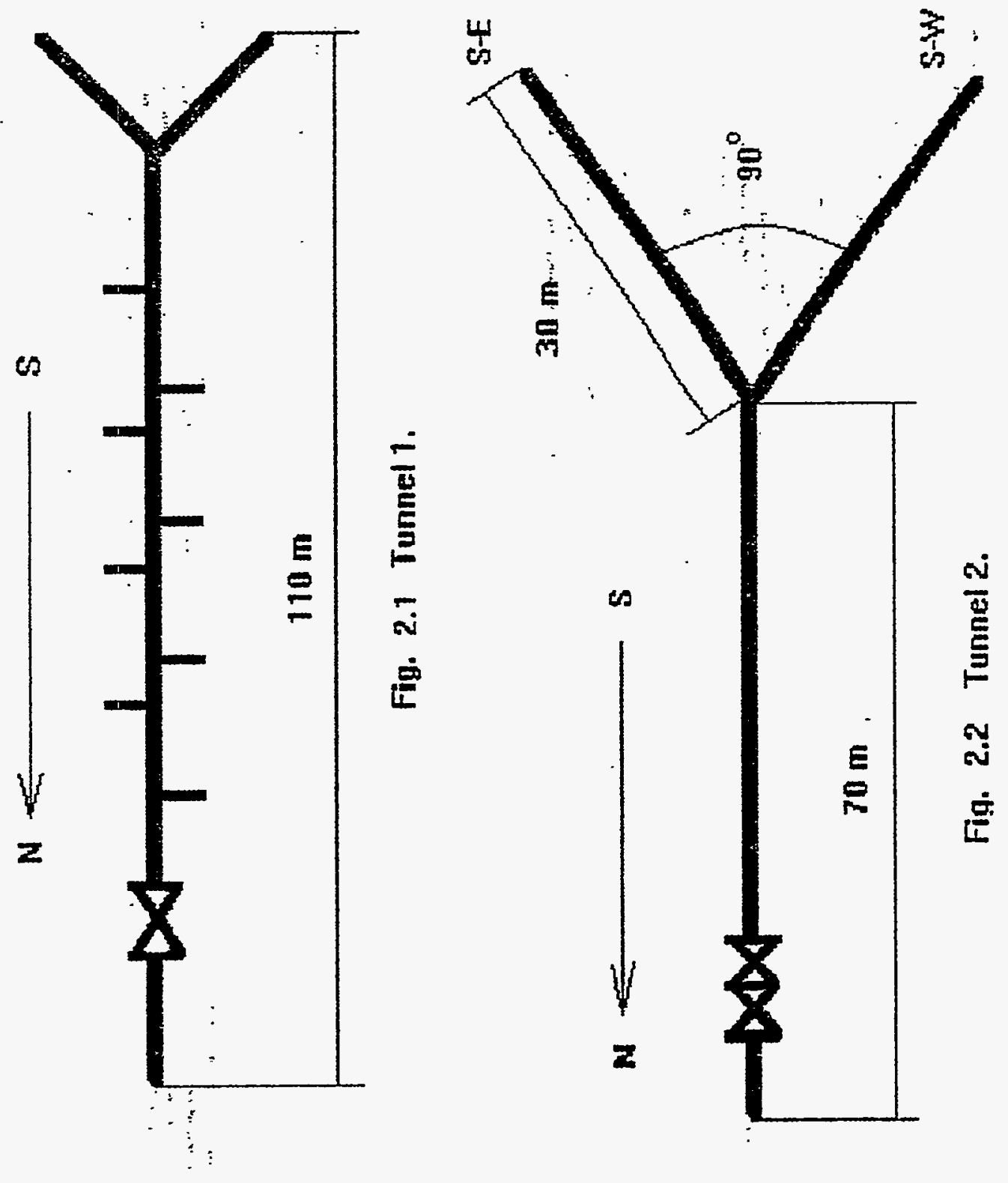


best equipped sites to conduct joint seismic and geophysical observations within the former Soviet union.

2.4. System of observations at the gas deposit in the Muynkum sands.

To study patterns of seismic wave fields above the gas bed, the Complex Seismologioal Expedition of the JIFE has carried out investigations at the Amangel "dy gas deposit in southern Kazakhstan (Fig.2.3). A study area is located in the central, and most difficult part of the Muyunkum desert. The sands have a complicated uneven relief', with barkhan dunes reaching 400 meters absolute elevation and relative elevations reaching about 40-60 meters. From the lithologic and stratigraphic composition of rooks and the velocity parameters of the upper part of the section and the thickness of the low-velocity zone the study area is divided into a few zones. A zone of development of an eolian sand deposits of early and middle quaternary age, with a thickness of 40-r0 meters has the widest distribution. It consists of dry sands (layer velocities $V_{s t=1100-1400}$ $\mathrm{m} / \mathrm{sec}$ ). These deposits are underlain by poorly consolidated sandstones, wet sands and clays $\left(V_{\mathrm{Bt}}=1700-2000 \mathrm{~m} / \mathrm{sec}\right)$.

The systern of observations and contours of the deposit are shown in Fig.2.4. Recording was carried out by ten ASS-6/12 magnetio recording stations with three-component. seismometers $5 M-3$ and $5-5-5$ continuosly for one month (with a magnifioation of about 1.5 milion in the frequency range 


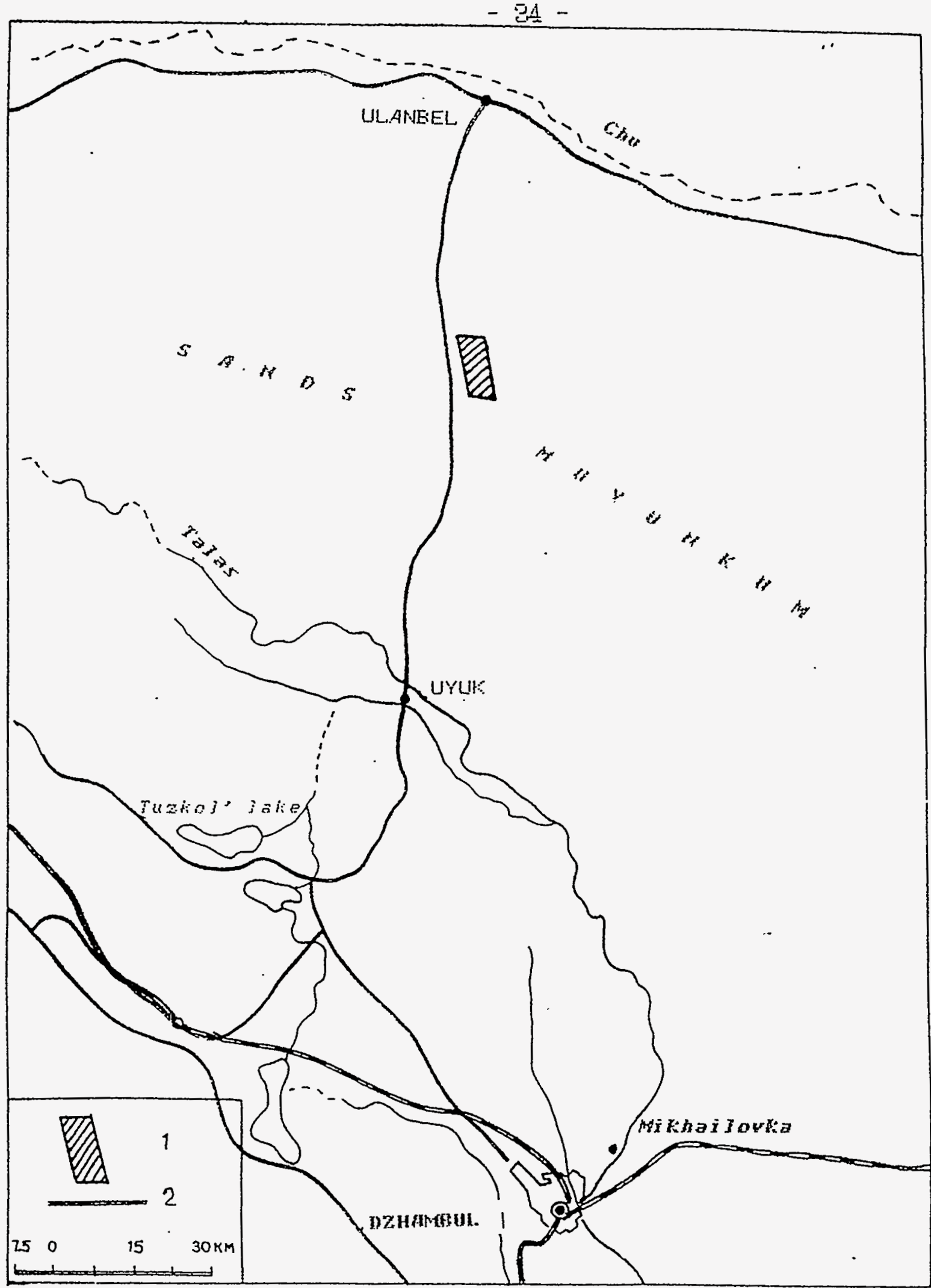

Fig. 2 Area of field works with the sejsmic array above the gas deposit. 1 - area of the works, 2 - main roads. 
$0.5-16 \mathrm{~Hz}$ ). For control, recording by the oscillographic record was also conduoted. The seismic information was recorded by the $A S S-6 / 12$ stations at two levels: high- and low-gain coarse, attenuated relative to the high-gain by 30 $\mathrm{dB}$. The magnetic recording stations were installed as a linear and cross-shaped system. Flaces of the seismometers installation are shown in Fig.2.3, by a triangle with a station number. We can see from Fig.2.3, that eight observation points were installed directly above the deposit and two outside it. Distances between the observation points are less in the central part of the deposit. The stations were installed mainly close to boreholes, which increased the acouracy of determination of coordinates. The distances between the stations were determined using a theodolite. As a result, a linear profile from eight stations was created, which coinsides with a seismographic profile $14 \mathrm{~A}-74$, for which a geophysical cross-seotion has been obtained.

In the field the stations were installed in metal boxes together with batteries. The seismometers were installed in conorete at a depth of about 40 centimetres. Horizontality of the seismometers was controlled by a level, and orientation of horizontal devices by compass. Then the boxes with the stations and seismometers were filled with a 10 on-thick soil layer. Distances between stations and seismometers were at least 10 meters. Such an installation provides a good thermal isolation and proteots from unfavorable influence of external conditions. Stations were working in rough conditions (daily temperature difference 


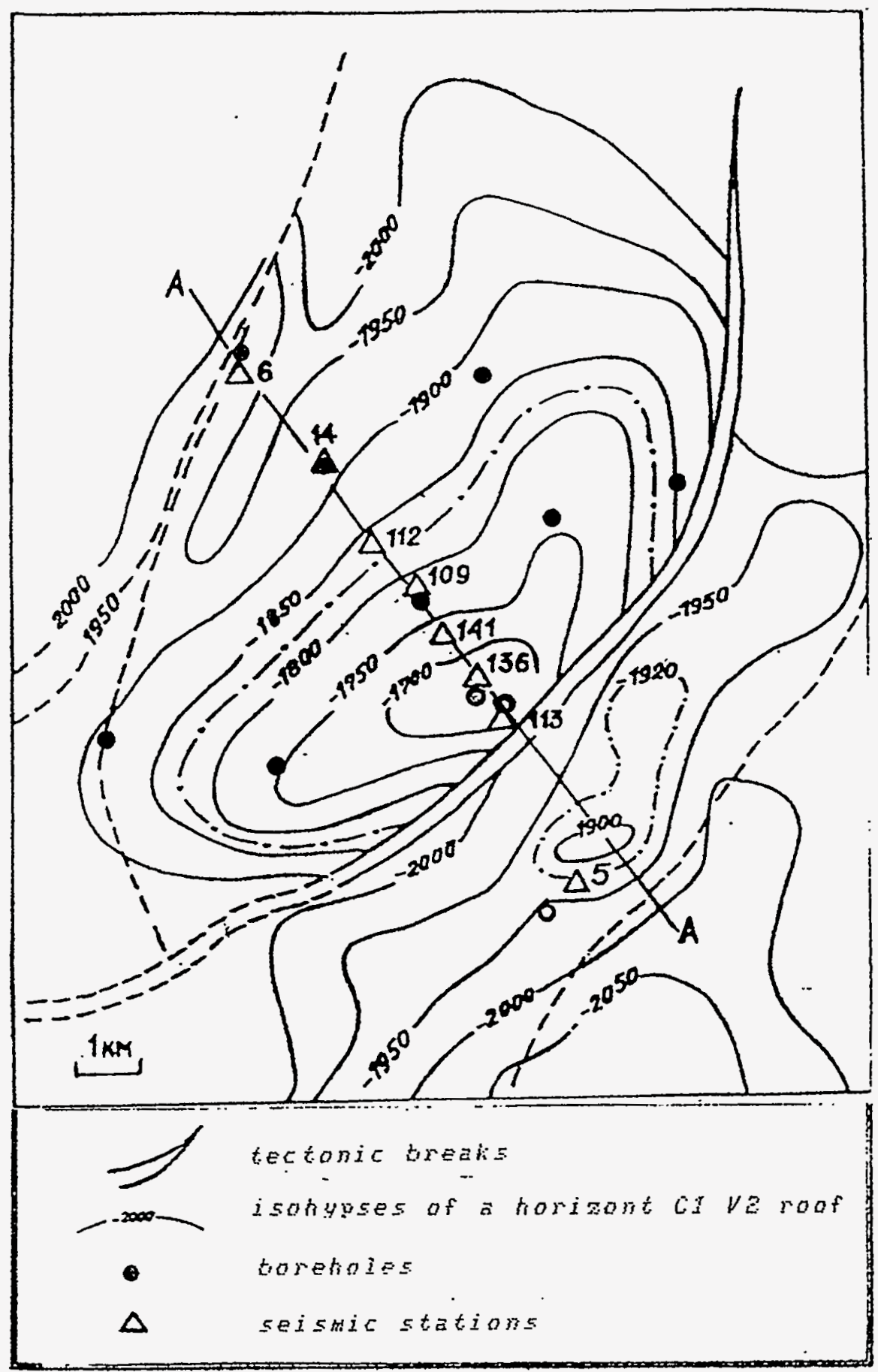

Fig. 2.4 System of investigation and a countor of the gas deposit "Amangel'dy". 
reached $30^{\circ} \mathrm{C}$, and strong winds and dust storms occured); for this reason the station operation was verified regularly. Station clocks correction were measured with an accuracy of $0.001 \mathrm{sec}$. The guality of the tape-drive mechanism work was checked (the speed of the tape drive was $0.5 \mathrm{~mm} / \mathrm{sec})$. The natural periods of the seismometers and levels of coil installation in the magnetio system of seismometers were also checked. Observations with the array were conducted from August 14 through September 27 ; 1984. During the work 2 underground nuclear explosions were recorded. In the data archives the records of one seismic station (number 109) are included (Fig.2.8). The station coordinates are: latitude $-44.38^{\circ} \mathrm{N}$, longitude $-71.35^{\circ} \mathrm{E}$.

More detailed information on the seismic array, methods of data processing and results obtained is appended in an article [Nersesov et al.,1990].

\subsection{System of observations at the small-aperture array.}

To study fine structure of the seismio wave fields the CSE organized in 1987 a temporary small-aperture array at a base $2 \times 2$ kilometers, consisting of 16 observation points.

The array was installed in 120 kilometers to the north from the city of Almaty, near the Malaisary ridge on the northern bank of the Ili river. The area is in the central part of the Eurasian conitinent, far from the sources of natural and artificial microseisms. Geologioal conditions 
are favorable for seismological investigations in this area. Bedrock of upper Faleozoio (Fza) are overiain by a thin layer of crushed rook and sandy deposits. Directly in the study area bedrook of the Malaisary Suite are represented by tuff-argillites and volcanio tuffs of dacitic-liparitio porphyrites. Outcrops of the rocks are found at the some seotions of erosive outs and along steep banks of the Ili river.

For the seismic information recording the RTS-AN system with aralog recording on two stations of the $A 55-6 / 12$ magnetio reoording system was used. 12 vertical seismometers were connected with one station (number 141), 4 sets of three-component devices with a second station (number 113). The recording was at one amplitude level. Sw-3 seismometers with a natural period of 2.0 sec were used. The devices were installed mainiy on a bedrook, in small tightly closed holes, which provided protection from the direot influence of wind and temperature variations. Seismometers were installed in cernent. Horizontality of the devices instalation was verified by a level. The data was sent from the seismometers to the reoording stations, placed in the center of the array, through wires.

A sohematio of the arrangement of equipment in 15 observation points is shown in Fig.2.5. As seen in this figure, three-component seismometers were installed along a grid $0.15 \times 0.15$ kilometers, within $a$ group of vertical devices (points $1-12$ ) in order that the two arrays compiemented each other. It was possible to use all the 


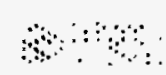

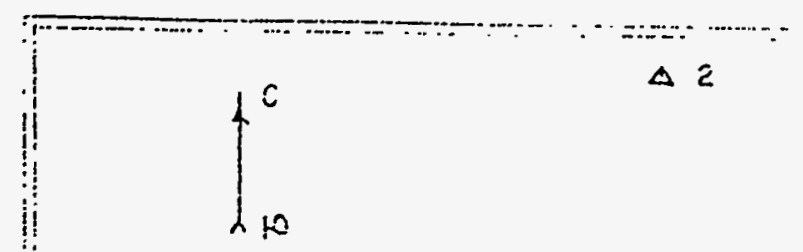

48

$\Delta 11$

$\Delta 10$

$\triangle 7$

$\vdots$
$\vdots$
$\vdots$
$\vdots$
$\vdots$
$\vdots$
$\vdots$

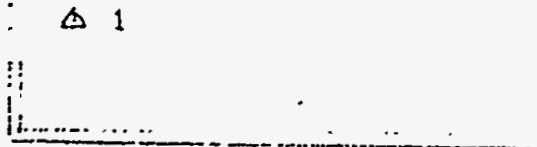

$\Delta a$

s 12
$613 \$ 18$

\& 14

45 : 5

L. $\varepsilon$ 
records in common processing of the data from the whole array. Io control data quality, one three-component station and one vertical device were installed at the same point (observation point number 14 ).

Fequirements to an acouraoy of detemining the relative coordinates of the observation points are rather high. For this reason the coordinates were determined with a I-50 theodolite using speoial methods. The accuracy obtained was about 1 meter at distant recording points. The coordinates of. the observation points in meters relative to the recording stations in the central part of the array are shown in Table 2.1. Coordinates of the center of the array are as follows: latitude $44.4^{\circ} \mathrm{N}$, longitude $70.77^{\circ} \mathrm{E}$.

Fecording the seismio information was carried out at a t.ape speed of $2 \mathrm{~mm} / \mathrm{sec}$ with a magnification about 1.5 million in the frequency range $0.5-16 \mathrm{~Hz}$. The maximum possible tape drive speed was chosen with the purpose of diminishing possible distortion, which can lead to large errors in data processing. In order to increase the accuracy of time determination at stations, we carried out a daily test of the quartz clooks for each station and restarted them based on precise timing signals using the reference clooks of the control unit.

The small-aperture array has been in operation from october 6 through october $31,198 \%$

The data obtained by the array in ar analog form were digitized by the AVSI-6 apparatus on the digital magnetio tape with subseguent oreation of archives on floppy-disks. 
Table $\quad 2.1$

Relative coordinates of the observation points (meters).

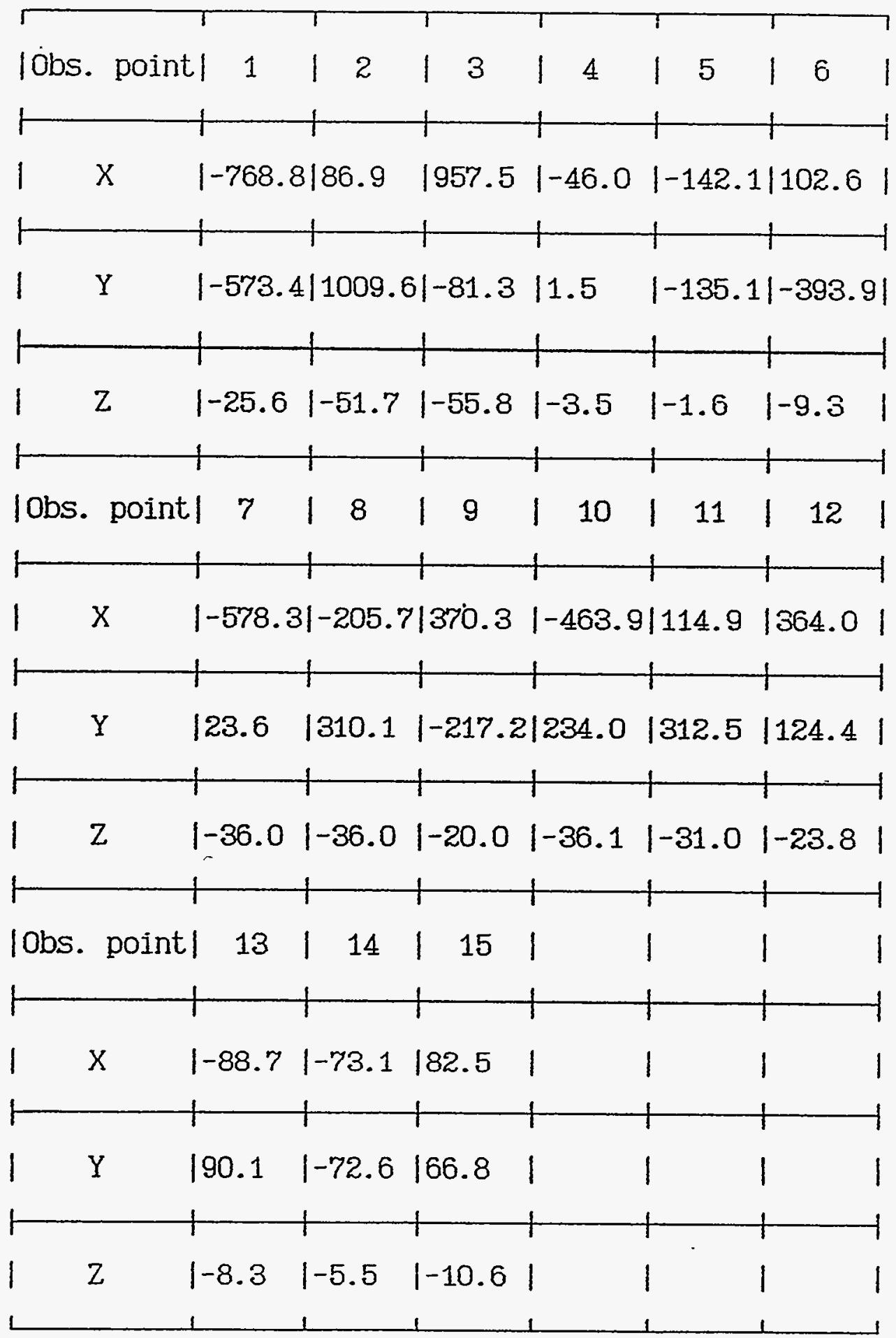


ङ. ARCHIVES OF THE DIGITAL DATA.

A major amount of the digital seismograms were received for the Talgar station (ASS-6/12 and PUSK-2), and $a$ oonsiderably smaller number for the temporary seismic arrays.

3.1. Digital data ohtained by the Talgar station.

Organization of the primary seismio data processing. Archival tapes prepared on AVSI-6 with the digital data were processed using the ES-1040 computer. The large volume of experimental material obtained and the possibility of repeated digitization of the seismio data (when necessary) allowed us to select high-guality digital records. For this purpose a program system has been developed which allows estination of the digitizing quality (stability of the sampling frequency, overflow of the UTP and non-linear distortion) and to reject records which do not correspond to pre-selected parameters. The rejected seisnograms were subjected to repeated digitization and testing. In the case of favorable test results the records were included in the archives.

3.1.1. Seismograms recorded by apparatus ASS.

Tabie 3.1 presents $a$ list of the digital seismograms 


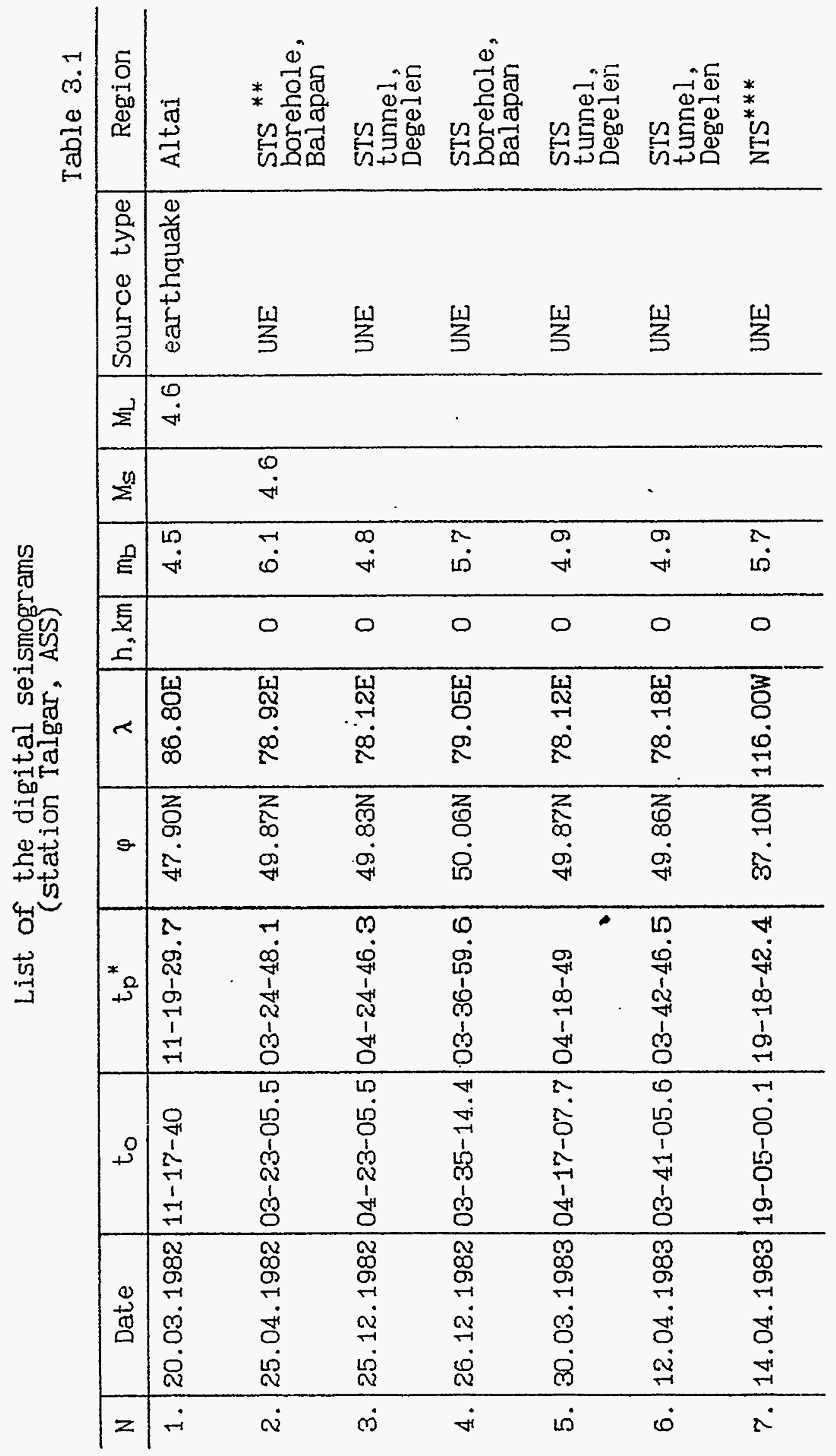




\begin{tabular}{|c|c|c|c|c|c|c|c|}
\hline 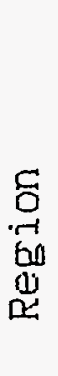 & 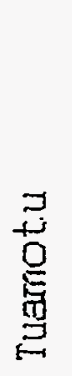 & 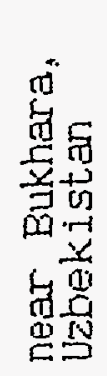 & 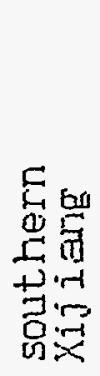 & 尝 & 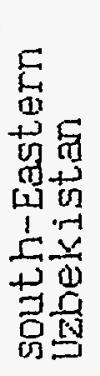 & 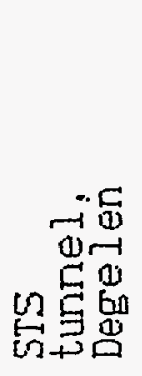 & 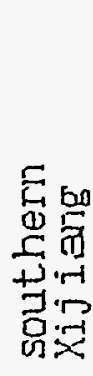 \\
\hline 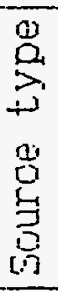 & $\stackrel{\text { 岁 }}{\leftrightarrows}$ & 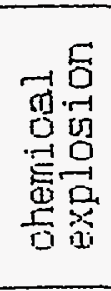 & $\begin{array}{l}\text { 耑 } \\
\text { 吾 } \\
\text { 苟 } \\
\text { a }\end{array}$ & 岂 & 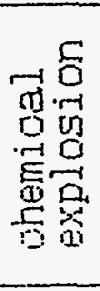 & 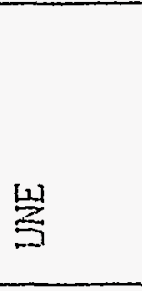 & 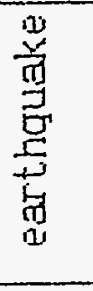 \\
\hline$\underline{X}$ & & & & & & & \\
\hline$\sum_{2}^{n}$ & & & & & & $\infty$ & \\
\hline$\stackrel{\text { I }}{\underline{E}}$ & $\begin{array}{l}60 \\
10\end{array}$ & i & $\begin{array}{l}\infty \\
-j\end{array}$ & $\begin{array}{l}0 \\
\text { in }\end{array}$ & Ij & $\begin{array}{l}\text { w) } \\
\text { Lj }\end{array}$ & تَّ \\
\hline $\begin{array}{l}\text { S } \\
\text { s. }\end{array}$ & 0 & $\stackrel{\vartheta}{\rightarrow}$ & m & 0 & 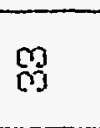 & 0 & 譶 \\
\hline$<$ & 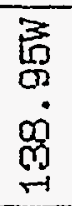 & 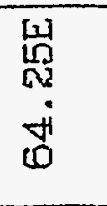 & 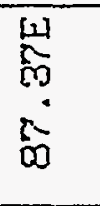 & 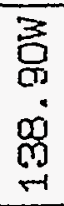 & $\begin{array}{l}\text { 岁 } \\
\text { g } \\
\dot{4} \\
0 \\
0\end{array}$ & 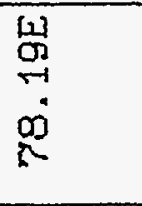 & $\begin{array}{l}\text { 山ी } \\
0 \\
0 \\
0\end{array}$ \\
\hline$\theta$ & 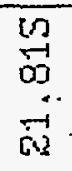 & 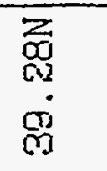 & $\begin{array}{l}Z \\
0 \\
0 \\
m \\
\forall\end{array}$ & $\begin{array}{l}0 \\
0 \\
01 \\
0 \\
0\end{array}$ & $\begin{array}{l}z \\
0 \\
\dot{0} \\
\dot{0}\end{array}$ & 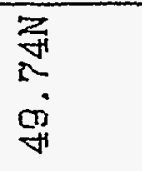 & 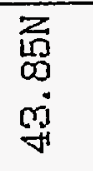 \\
\hline م & 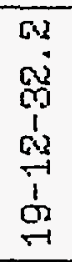 & 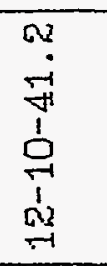 & \begin{tabular}{l}
$x$ \\
0 \\
0 \\
1 \\
1 \\
0 \\
1 \\
1 \\
0 \\
\hdashline
\end{tabular} & $\begin{array}{l}c 0 \\
0 \\
0 \\
1 \\
1 \\
1 \\
1 \\
i=1\end{array}$ & $\begin{array}{l}5 \\
8 \\
0 \\
1 \\
0 \\
1 \\
1 \\
0\end{array}$ & $\begin{array}{l}+1 \\
+1 \\
0 \\
1 \\
1 \\
1 \\
1 \\
0 \\
0\end{array}$ & 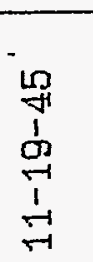 \\
\hline+3 & $\begin{array}{l}2 \\
00 \\
00 \\
1 \\
0 \\
10 \\
1 \\
0 \\
0 \\
0\end{array}$ & $\begin{array}{l}m \\
0 \\
9 \\
1 \\
0 \\
1 \\
1 \\
0 \\
01\end{array}$ & $\begin{array}{l}0 \\
0 \\
1 \\
8 \\
1 \\
1 \\
0\end{array}$ & $\begin{array}{l}\infty \\
0 \\
01 \\
1 \\
0 \\
0 \\
1 \\
x \\
r-1\end{array}$ & 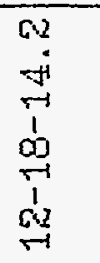 & $\begin{array}{l}\infty \\
j \\
j \\
1 \\
1 \\
0 \\
1 \\
0 \\
0\end{array}$ & $\begin{array}{l}8 \\
0 \\
1 \\
-1 \\
1 \\
7 \\
7\end{array}$ \\
\hline $\begin{array}{l}\stackrel{0}{+} \\
\frac{\pi}{0} \\
\end{array}$ & 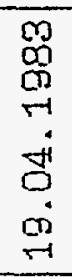 & 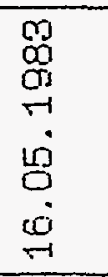 & $\begin{array}{l}m \\
0 \\
0 \\
\sigma \\
0 \\
\dot{0} \\
\dot{0} \\
\dot{0} \\
-1\end{array}$ & $\begin{array}{l}m \\
\dot{m} \\
0 \\
01 \\
\dot{0} \\
\dot{0} \\
\dot{0} \\
\dot{0}\end{array}$ & 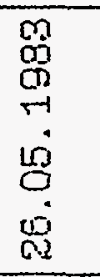 & $\begin{array}{l}m \\
0 \\
0 \\
\sim \\
\dot{0} \\
\dot{0} \\
\dot{8} \\
\dot{0}\end{array}$ & $\begin{array}{l}m \\
0 \\
0 \\
\square \\
\dot{0} \\
\dot{0} \\
\dot{0} \\
\dot{0}\end{array}$ \\
\hline$z$ & $\dot{a j}$ & $\dot{\sigma r}$ & $\dot{\theta}$ & $\stackrel{-1}{-1}$ & $\underset{a l}{a}$ & $\underset{\rightarrow}{\mathfrak{m}}$ & $\underset{-1}{-1}$ \\
\hline
\end{tabular}




\begin{tabular}{|c|c|c|c|c|c|c|c|c|c|c|c|}
\hline $\mathrm{N}$ & Date & $t_{0}$ & $t_{p}$ & $\varphi$ & $\lambda$ & $\mathrm{h}, \mathrm{knn}$ & $m_{b}$ & $M_{\Omega}$ & $M_{L}$ & Source type & Region \\
\hline 15. & 09.06 .1983 & $06-25-16$ & $06-2 \gamma-44$ & $39.70 \mathrm{~N}$ & $90.00 E$ & & 4.4 & & & earthquake & $\begin{array}{l}\text { southern } \\
\text { Xijiang }\end{array}$ \\
\hline 16. & 12.06 .1983 & $02-36-43.7$ & $02-38-26.6$ & $49.90 \mathrm{~N}$ & $78.97 \mathrm{E}$ & 0 & 6.1 & 4.8 & & UNE & $\begin{array}{l}\text { STS } \\
\text { borehole. } \\
\text { Balapan }\end{array}$ \\
\hline 17. & 18.06 .1983 & $12-06-21$ & $12-07$ & $47.30 \mathrm{~N}$ & $81.60 \mathrm{E}$ & & & & 3.6 & earthquake & Altai \\
\hline 18. & 24.06 .1983 & $02-56-11.2$ & $02-57-50.5$ & $49.82 \mathrm{~N}$ & $78.12 \mathrm{E}$ & 0 & 4.7 & & & UNE & $\begin{array}{l}\text { STS } \\
\text { tunnel, } \\
\text { Degelen }\end{array}$ \\
\hline 19. & 28.06 .1983 & $17-45-59$ & $18-05$ & 21.705 & $138.94 \mathrm{~W}$ & 0 & 5.4 & & & UNE & Tuamotu \\
\hline 20 . & 30.06 .1983 & $21-39-58.5$ & $\begin{array}{c}21-47-27.5 \\
:\end{array}$ & $43.32 \mathrm{~N}$ & $45.70 E$ & 16 & 4.6 & & & earthquake & Caucasus \\
\hline 21. & 19.02 .1984 & $03-57-03.5$ & $03-58-45.3$ & $49.86 \mathrm{~N}$ & $78.80 E$ & 0 & 5.9 & 4.7 & & UNE & $\begin{array}{l}\text { STS } \\
\text { borehole, } \\
\text { Ealapan }\end{array}$ \\
\hline
\end{tabular}




\begin{tabular}{|c|c|c|c|c|c|c|c|}
\hline 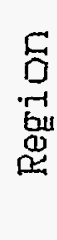 & 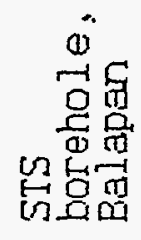 & 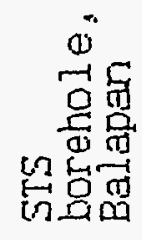 & 点 & 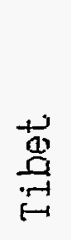 & 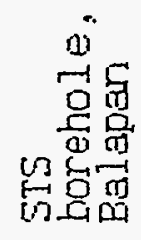 & $\stackrel{w}{z}$ & 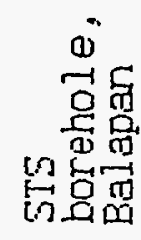 \\
\hline $\begin{array}{l}0 \\
3 \\
3 \\
3 \\
0 \\
0 \\
0 \\
0 \\
0 \\
0\end{array}$ & 号 & 吕 & 岂 & 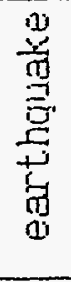 & 吕 & 岂 & 岂 \\
\hline$\vec{\Sigma}$ & & & & & & & \\
\hline & $\square$ & & ? & & $\infty 1$ & Cos & $\infty$ \\
\hline$\Sigma$ & $\nabla^{\prime}$ & & זi & & $\dot{\nabla}$ & ji & นิ \\
\hline & 2 & on & $r$ & 0 & 0 & $m$ & -1 \\
\hline 崖 & 10 & "ن & نे & نטا & $\dot{\theta}$ & ธن & $\infty$ \\
\hline$\underline{s}$ & 0 & D & 0 & & 0 & 0 & D \\
\hline$\alpha$ & $\begin{array}{l}\mu \nu \\
\sigma \pi \\
0 \\
00\end{array}$ & $\begin{array}{l}\text { L } \\
\text { [n } \\
0 \\
0\end{array}$ & 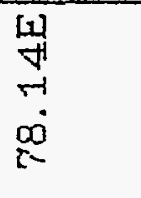 & $\begin{array}{l}\mu \\
0 \\
0 \\
0 \\
01\end{array}$ & $\begin{array}{l}\frac{1}{0} \\
0 \\
0 \\
0\end{array}$ & \begin{tabular}{l}
3 \\
0 \\
0 \\
0 \\
0 \\
\hdashline-1
\end{tabular} & $\begin{array}{l}\text { 너 } \\
8 \\
0 \\
\text { d } \\
2\end{array}$ \\
\hline 9 & $\begin{array}{l}z \\
8 \\
0 \\
0\end{array}$ & $\begin{array}{l}\sum_{0} \\
\infty \\
\vdots \\
0 \\
\forall\end{array}$ & \begin{tabular}{l}
$z$ \\
a \\
$a$ \\
$\dot{9}$ \\
\hdashline
\end{tabular} & $\begin{array}{l}z \\
\text { z } \\
\text { कं }\end{array}$ & $\begin{array}{l}z \\
\stackrel{8}{a} \\
\dot{q} \\
\dot{q}\end{array}$ & 超 & $\begin{array}{l}\text { 경 } \\
\text { g. } \\
\text { gi }\end{array}$ \\
\hline م & $\begin{array}{l}a \\
0 \\
0 \\
1 \\
7 \\
7 \\
1 \\
0 \\
0\end{array}$ & $\begin{array}{l}\stackrel{4}{1} \\
\stackrel{1}{1} \\
\dot{\omega} \\
1 \\
1 \\
0\end{array}$ & $\begin{array}{l}m \\
0 \\
0 \\
\forall \\
1 \\
0 \\
\dddot{1} \\
\vdots \\
0 \\
0\end{array}$ & $\begin{array}{l}\infty \\
0 \\
10 \\
1 \\
0 \\
0 \\
1 \\
0 \\
0\end{array}$ & 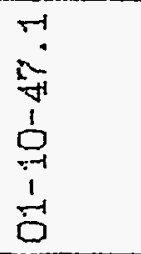 & 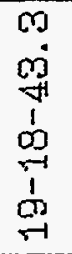 & 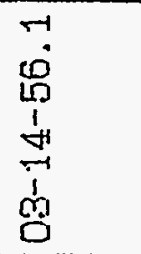 \\
\hline & $\begin{array}{l}4 \\
0 \\
0 \\
1 \\
0 \\
1 \\
1 \\
0 \\
0\end{array}$ & $\begin{array}{l}m \\
0 \\
0 \\
1 \\
0 \\
0 \\
1 \\
1 \\
0\end{array}$ & $\begin{array}{l}m \\
\dot{0} \\
0 \\
1 \\
\\
\dot{1} \\
0 \\
0\end{array}$ & $\begin{array}{l}02 \\
7 \\
1 \\
0 \\
1 \\
1 \\
81 \\
0\end{array}$ & $\begin{array}{l}5 \\
0 \\
0 \\
1 \\
9 \\
0 \\
1 \\
0 \\
0\end{array}$ & $\begin{array}{l}8 \\
0 \\
1 \\
0 \\
1 \\
0 \\
0\end{array}$ & 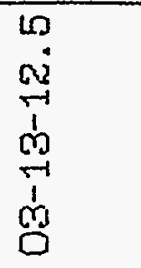 \\
\hline 崩 & $\begin{array}{l}4 \\
0 \\
0 \\
-1 \\
0 \\
0 \\
5 \\
0\end{array}$ & 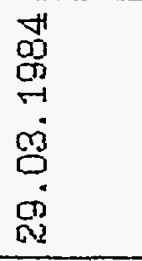 & 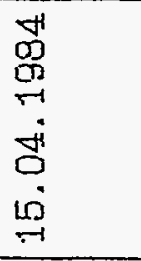 & 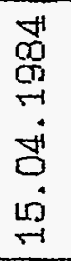 & 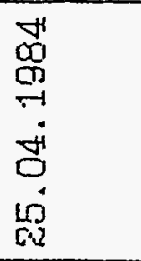 & 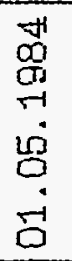 & 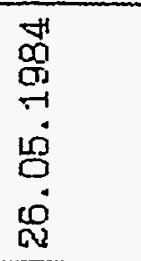 \\
\hline$z$ & $\vec{\alpha}$ & $\dot{m}$ & मi & 100 & $\frac{0}{\alpha}$ & $\frac{\pi}{n}$ & $\dot{\alpha}$ \\
\hline
\end{tabular}




\begin{tabular}{|c|c|c|c|c|c|c|c|}
\hline 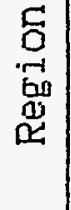 & $\stackrel{\mathscr{G}}{=}$ & $\stackrel{0}{\leftrightarrow}$ & 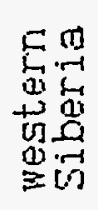 & 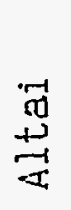 & 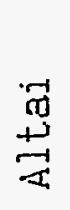 & 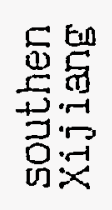 & 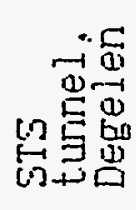 \\
\hline 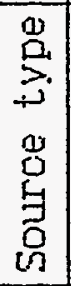 & 岂 & 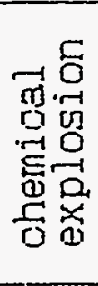 & 岾 & 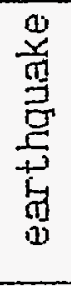 & 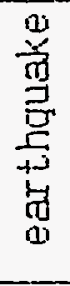 & 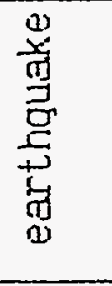 & 岂 \\
\hline $\overrightarrow{\underline{\Sigma}}$ & & & & $\frac{a}{c i}$ & $a$ & & \\
\hline$\sum^{n}$ & $\vec{H}$ & & $\vec{\infty}$ & & & . & \\
\hline 票 & $\begin{array}{l}\infty \\
\text { L }\end{array}$ & & $\begin{array}{l}m \\
10\end{array}$ & & & di & ס \\
\hline $\begin{array}{l}\bar{\Xi} \\
\pm\end{array}$ & 0 & & 0 & & & $\stackrel{\oplus}{\rightarrow}$ & 0 \\
\hline$\alpha$ & $\begin{array}{l}\vec{z} \\
0 \\
\infty \\
\stackrel{-}{-1}\end{array}$ & & 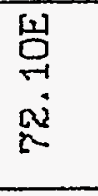 & $\begin{array}{l}\text { 岁 } \\
0 \\
0 \\
0\end{array}$ & 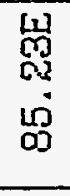 & 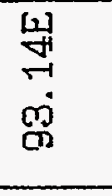 & $\begin{array}{l}\text { 씸 } \\
\text { 임 } \\
00\end{array}$ \\
\hline 5 & $\begin{array}{l}z \\
0 \\
0 \\
0\end{array}$ & & $\begin{array}{l}z \\
0 \\
\dot{0} \\
\dot{0}\end{array}$ & $\begin{array}{l}Z \\
0 \\
0 \\
0\end{array}$ & 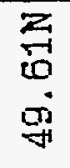 & $\begin{array}{l}z \\
\text { \& } \\
-1 \\
-1 \\
\forall 1\end{array}$ & $\begin{array}{l}z \\
0 \\
\infty \\
g \\
q\end{array}$ \\
\hline$+\frac{0}{3}$ & 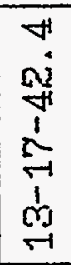 & & 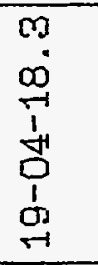 & $\begin{array}{l}\text { 10 } \\
0 \\
0 \\
1 \\
1 \\
0 \\
1 \\
1 \\
0 \\
0\end{array}$ & $\begin{array}{l}m \\
0 \\
1 \\
1 \\
0 \\
1 \\
6 \\
-1 \\
-1\end{array}$ & $\begin{array}{l}-1 \\
-1 \\
0 \\
1 \\
0 \\
0 \\
1 \\
0 \\
0\end{array}$ & 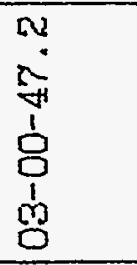 \\
\hline+3 & $\begin{array}{l}+1 \\
8 \\
8 \\
1 \\
0 \\
0 \\
1 \\
0 \\
4\end{array}$ & $\begin{array}{l}5 \\
1 \\
0 \\
0\end{array}$ & $\begin{array}{l}I \\
09 \\
09 \\
19 \\
1 \\
0 \\
0 \\
1 \\
0 \\
q\end{array}$ & $\begin{array}{l}\frac{a}{0} \\
1 \\
9 \\
1 \\
1 \\
0 \\
0\end{array}$ & $\begin{array}{l}0 \\
0 \\
0 \\
1 \\
0 \\
0 \\
1 \\
0 \\
0\end{array}$ & $\begin{array}{l}Q \\
\mathfrak{m} \\
\mathfrak{m} \\
\mathfrak{w} \\
\dot{1} \\
\mathfrak{b}\end{array}$ & $\begin{array}{l}0 \\
0 \\
0 \\
1 \\
0 \\
10 \\
1 \\
0 \\
0\end{array}$ \\
\hline 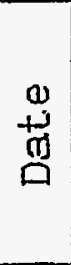 & $\begin{array}{l}\vec{H} \\
0 \\
0 \\
-1 \\
\dot{0} \\
0 \\
\dot{0} \\
\dot{m}\end{array}$ & 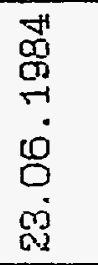 & $\begin{array}{l}\text { से } \\
0 \\
0 \\
\sim \\
0 \\
0 \\
0 \\
10\end{array}$ & 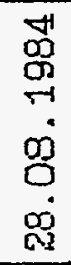 & 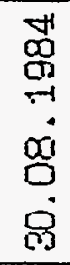 & 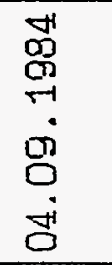 & 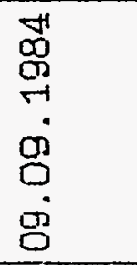 \\
\hline$z$ & $\begin{array}{l}a \\
0 \\
0\end{array}$ & $\dot{8}$ & $\overrightarrow{\dot{m}}$ & $\stackrel{\infty}{m}$ & $\stackrel{m}{m}$ & ले & ตั \\
\hline
\end{tabular}




\begin{tabular}{|c|c|c|c|c|c|c|c|}
\hline 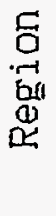 & $\stackrel{n}{\leftrightarrow}$ & 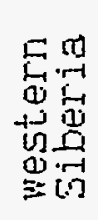 & 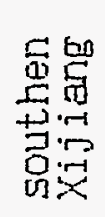 & $\begin{array}{r}\pi \\
+\pi \\
+\pi\end{array}$ & 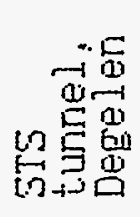 & $\stackrel{\mathscr{W}}{\rightleftarrows}$ & 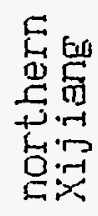 \\
\hline 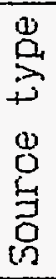 & 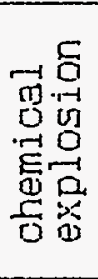 & 岕 & 岀 & 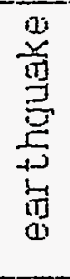 & 片 & 岂 & 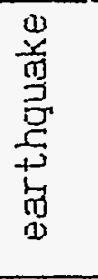 \\
\hline$\vec{\Sigma}$ & & & & $\bar{y}$ & & & \\
\hline$\sum$ & & & & & & & \\
\hline$\stackrel{\Omega}{E}$ & \& & ס & ז' & & us & In & $\begin{array}{l}+1 \\
\dot{\pi}\end{array}$ \\
\hline$\underline{\underline{E}}$ & 0 & 0 & 0 & & 0 & 0 & $\stackrel{\infty}{\Omega}$ \\
\hline$<$ & 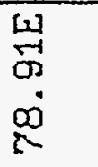 & 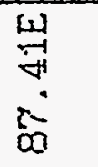 & $\begin{array}{l}14 \\
0 \\
\infty \\
\infty\end{array}$ & $\begin{array}{l}\text { no } \\
\text { - } \\
\text { को }\end{array}$ & $\begin{array}{l}\text { 㟧 } \\
\stackrel{-1}{0} \\
0 \\
0\end{array}$ & 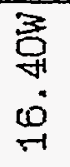 & 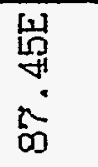 \\
\hline$s$ & 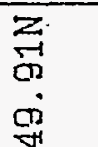 & $\begin{array}{l}Z_{+1} \\
0 \\
0 \\
01\end{array}$ & 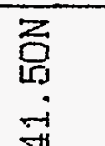 & z & $\begin{array}{l}z \\
\text { zo } \\
\text { du } \\
\text { gi }\end{array}$ & $\begin{array}{l}z \\
\text { zo } \\
\text { c }\end{array}$ & $\begin{array}{l}Z \\
\text { 点 } \\
\dot{m}\end{array}$ \\
\hline$\stackrel{\Omega}{2}$ & $\begin{array}{l}+1 \\
0 \\
0 \\
1 \\
1 \\
0 \\
\dot{1} \\
\dot{0}\end{array}$ & $\begin{array}{l}\dot{0} \\
\dot{a} \\
\overrightarrow{1} \\
\dot{1} \\
0 \\
\frac{1}{a} \\
\vec{\alpha}\end{array}$ & $\begin{array}{l}0 \\
0 \\
\vdots \\
0 \\
0\end{array}$ & $\begin{array}{c}-1 \\
\dot{0} \\
\dot{1} \\
\dot{m} \\
\stackrel{1}{1} \\
\dot{1}-1\end{array}$ & $\begin{array}{l}+1 \\
0 \\
y \\
1 \\
0 \\
0 \\
1 \\
4 \\
0\end{array}$ & 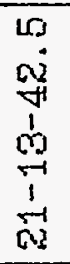 & \begin{tabular}{l}
0 \\
0 \\
0 \\
0 \\
1 \\
\multirow{1}{*}{} \\
0 \\
1 \\
0 \\
0
\end{tabular} \\
\hline 3 & $\begin{array}{l}5 \\
1 \\
1 \\
10 \\
1 \\
0 \\
0\end{array}$ & $\begin{array}{l}+1 \\
0 \\
0 \\
1 \\
0 \\
0 \\
1 \\
0 \\
0\end{array}$ & $\begin{array}{l}0 \\
0 \\
1 \\
1 \\
9 \\
1 \\
1 \\
1 \\
0\end{array}$ & 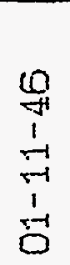 & $\begin{array}{l}0 \\
0 \\
1 \\
6 \\
1 \\
1 \\
0 \\
0\end{array}$ & $\begin{array}{l}8 \\
0 \\
0 \\
0 \\
1 \\
\qquad 1 \\
\infty\end{array}$ & $\begin{array}{l}0 \\
q \\
1 \\
8 \\
0 \\
1 \\
10 \\
0\end{array}$ \\
\hline & 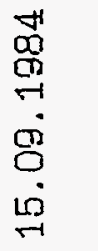 & 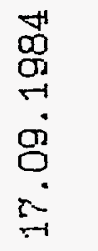 & 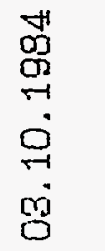 & 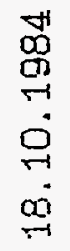 & 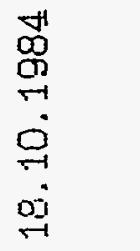 & \begin{tabular}{l}
0 \\
0 \\
0 \\
\hdashline \\
$\vdots$ \\
0 \\
$\vdots$ \\
\hdashline
\end{tabular} & \begin{tabular}{l}
0 \\
0 \\
0 \\
\hdashline \\
\\
0 \\
0 \\
0 \\
0
\end{tabular} \\
\hline$z$ & $\dot{m}$ & 侘 & $\dot{\alpha j}$ & $\dot{\phi}$ & $\dot{\theta}$ & $\underset{\forall}{+}$ & $\underset{\sim}{\sim}$ \\
\hline
\end{tabular}




\begin{tabular}{|c|c|c|c|c|c|c|c|c|c|c|c|}
\hline$N$ & Date & $t_{0}$ & $t_{p}$ & $\varphi$ & $\lambda$ & $\mathrm{h}, \mathrm{km}$ & $I_{b}$ & $M=$ & $M_{L}$ & Source type & Region \\
\hline 43. & 24.08 .1986 & $00-27-16$ & $00-29-49.6$ & $41.02 E$ & $91.50 E$ & & & 4.3 & & esrthquake & $\begin{array}{l}\text { southern } \\
\text { Xijiane }\end{array}$ \\
\hline 44. & 16.09 .1986 & $10-36-27$ & $10-37-42.7$ & $47.40 \mathrm{~N}$ & $82.60 \mathrm{E}$ & & & & 3.3 & earthquake & Altai \\
\hline 45. & 19.11 .1986 & $12-50-06$ & $12-51-17.8$ & $47.81 \mathrm{~N}$ & $80.85 E$ & & & & 3.9 & ear thquake & Altai \\
\hline 46. & 20.11 .1986 & $|02-40-24.3|$ & $|02-41-45.1|$ & $41.95 \mathrm{~N}$ & $84.10 \mathrm{E}$ & 33 & 4.6 & & & earthquake & $\begin{array}{l}\text { southern } \\
\text { Xijiang }\end{array}$ \\
\hline 47. & 26.02 .1987 & $04-58-22$ & $05-00-03.7$ & 49.8013 & $78.10 \mathrm{E}$ & 0 & 5.4 & & & LNNE & $\begin{array}{l}\text { STS } \\
\text { tunnel } \\
\text { Degeler }\end{array}$ \\
\hline 48. & 14.09 .1989 & $|03-59-57.6|$ & $|04-01-39.5|$ & $49.80 \mathrm{~N}$ & $79.80 E$ & 0 & 6.1 & 4.8 & & UNE & $\begin{array}{l}\text { STS } \\
\text { borehole, } \\
\text { Balapan }\end{array}$ \\
\hline 49. & 13.10 .1988 & $14-00-00$ & $14-13-43$ & $37.09 \mathrm{~N}$ & 16.50W & 0 & 5.9 & 4.4 & & UNAE & NTS \\
\hline 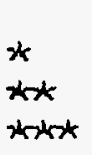 & $\begin{array}{l}t_{p} \text { - time } \\
\text { STS - Semi } \\
\text { NTS - Neva }\end{array}$ & $\begin{array}{l}\text { of P-wave } \\
\text { ipalatinsk } \\
\text { gda test sit }\end{array}$ & $\begin{array}{l}\text { arrival } \\
\text { test site. } \\
\text { te. }\end{array}$ & & & & & & & & \\
\hline
\end{tabular}


recorded using the ASS system, installed at the Talgar station (see also Fig.1.1.). In all, 49 reoords of earthquakes, chemical explosions, and nuclear explosions were digitized. According to the contract. the majority of the records are the seismograms of underground nuclear expiosions at regional distances. 18 seismograms of underground nolear explosions from the Semipalatinsk test. site (9 from the Balapan area and 9 from the Degelen area), one seismogram of an underground nuciear expiosion from the chinese test site Lop Nor and one seismograrn of an industrial nuolear explosion from West siberia were digitized. In addition, 4 records of chemical explosions were obtained ( 2 from the Semipalatinsk test site area and 2 from the Uzbekistan region). 6 seismograns of earthquakes from the Altai region with epicenters close to the Semipalatinsk test site were also digitized. There are 8 earthquake records from west china region, close to the Lop Nor test site and also 2 records of earthquakes from other regions of Eurasia (Tibet and Caucasus) in the our data arohives. Finally, 7 seismograms of underground nuclear explosions from the other test sites ( 4 from the Nevada test. site and 3 from the French test site in the Paoific ocean) were digitized.

All seismograns are 3 -component $(\mathrm{N}-\mathrm{S}, \mathrm{E}-\mathrm{W}, \mathrm{Z})$, and were digitized with a freguency of $25 \mathrm{~Hz}$ (for the period $1982-1984)$ and $20 \mathrm{~Hz}$ (1986-1988). The record length varies from 380 to 410 seo. In pages $58-104$ the records of all events obtained at regional distances are shown. 
Fig.1.2 shows frequenoy characteristios of the channels. For the events $\mathrm{N} 1-40$ (Table 3.1.) the frequency response was constart over the frequency range $0.5-8 \mathrm{~Hz}$, for the events $N 41-49$, over the range $0.5-16 \mathrm{~Hz}$. The magnification was about 480000 .

File structure. All the data are described in the two first lines of the header. In the first line, information on an event recorded is indioated, which includes the following data: station name; $t_{p}$ - time of F-wave arrival; event coordinates; hypocentral depth and magnitude.

In the second line, information on the seismogram is indicated: date and time of the first data point (the first 6 numbers are following: year, month, day, hour, minute, and second). Then station number follows (non-essential information); then the magnification of the record in $d B$ when digitizing; $V_{r d}, V_{W r}$ - non-essential information; then the sampling rate in $\mathrm{Hz}$; number of channel (from 1 to 12 , non-essential information); in the last position, seismometer type (horizontal or vertical).

For example: the file name 02260459.109; here 02 is the month, 26 the day, 04 is the hour, 59 is the minute, 109 is the station number.

The title of this file is the following:

Station: Talgar $t_{0}=04-58-22 \quad t_{p}=05-00-03.749 .80 N$ \% $9.10 E h=0$ $\mathrm{M}_{\mathrm{L}}=5.48 \mathrm{gr} \quad 226 \quad 45955 \quad 109 \quad 63 \mathrm{dE} \quad \mathrm{V}_{\mathrm{rd}}=50 \quad \mathrm{~V}_{\mathrm{wr}}=.5 \quad 20.00 \mathrm{~Hz}$ channel- $7(E-W)$.

The station nane - Talgar, origin time to=04-58-22, time of $P$-wave arrival- $t_{\mathrm{p}}=05-00-03.7$ : explosion coordinates 
- $49.80 \mathrm{~N}, 78.10 \mathrm{E}$, the depth $\mathrm{h}=0 \mathrm{~km}$, magnitude $\mathrm{m}_{\mathrm{b}}=5.4$.

The date and time of the first data point: $1900+8 f^{\prime}=1987$ (year), 2 is the month, 26 is the day, 04 is the hour; 59 is the minute, 55 is the second, 109 is the station number, the attenuation $-63 \mathrm{dE}$ (it is necessary to multiply ali numbers before an interpretation by $\left.10^{(83 / 20)}\right), 20.00 \mathrm{~Hz}$ is the digitization frequenoy, $E-W$ the seismometer azimuth. The second line of the titie is appended before the data for a given chanei in file.

The same file structure corresponds to the digital seisnograms obtained by the seismic arrays (see below).

\subsubsection{Seismograns recorded by the apparatus PUSK-2.}

In Table 3.2. a list of digital seismograms, obtained by the apparatus PUSK-2 is indicated.

In $\mathrm{all}, 4$ earthquakes and 3 underground nuclear explosions records were picked out. 2 nuclear explosions originated from the Semipalatinsk test site (the Balapan area), and one at the Lop Nor test site. Records of earthquakes from Eorokhoro ridge (eastern Kazakhstan), southern Xinjiang, and Tibet were also pioked out.

The seismograms are three-component, but in some cases due to an instrunent fault the reoords of one of the horizontal channels are absent. The digitization freguency in ail cases was $100 \mathrm{~Hz}$.

File structure. In the first line of the header 
List of the digital seismograms (station Talgar. PUSK-2)

Table 3.2

\begin{tabular}{|c|c|c|c|c|c|c|c|c|c|c|c|}
\hline$N$ & Date & $t_{0}$ & $t_{p}$ & $\varphi$ & $\lambda$ & $\mathrm{h}, \mathrm{km}$ & $m_{b}$ & $M \Xi$ & $M_{L}$ & Source type & Fegion \\
\hline 1. & 06.08 .1988 & $04-58-02$ & $04-58-28.0$ & $44.60 \mathrm{~N}$ & $78.60 E$ & 0 & & & 3.4 & earthquake & $\begin{array}{l}\text { Borokhoro } \\
\text { ridge }\end{array}$ \\
\hline 2. & 29.09 .1988 & $07-00-02$ & $07-02-09.5$ & $41.52 \mathrm{~N}$ & $88.15 E$ & 0 & 4.6 & & & UNE & Lop Nor \\
\hline 3. & 04.04 .1389 & $13-29-51$ & $13-30-41.7$ & $44.40 \mathrm{~N}$ & $80.60 \mathrm{E}$ & 0 & & & 3.4 & earthquake & $\begin{array}{l}\text { Eorokhoro } \\
\text { ridge }\end{array}$ \\
\hline 4. & 02.09 .1989 & $04-16-57$ & $04-18-41.0$ & $50.03 \mathrm{~N}$ & $79.02 E$ & 0 & 5.1 & 4.1 & & LWNE & $\begin{array}{l}\text { STS }^{* *} \\
\text { borehole. } \\
\text { Balapan }\end{array}$ \\
\hline 5. & $08 \cdot 10 \cdot 1989$ & $15-49-29$ & $15-51-28.3$ & $36.35 \mathrm{~N}$ & $82.68 \mathrm{E}$ & 10 & 5.1 & 4.7 & & earthquake & $\begin{array}{l}\text { southern } \\
\text { Xinjiane }\end{array}$ \\
\hline 6. & 19.10 .1989 & $09-49-57$ & $09-51-39.8$ & $49.90 \mathrm{~N}$ & $78.97 \mathrm{E}$ & 0 & 5.9 & 5.0 & & UNE & $\begin{array}{l}\text { STS } \\
\text { borehole. } \\
\text { Balapan }\end{array}$ \\
\hline 7. & $|09.01 .1990|$ & $\mid 02-29-21$ & $|02-33-24.5|$ & $28.15 \mathrm{~N}$ & $88.11 E$ & 35 & 5.7 & 4.3 & & eartrousuke & Tibet \\
\hline 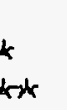 & $\begin{array}{l}t_{p}-\text { time } \\
\text { STs - Semi }\end{array}$ & $\begin{array}{l}\text { of P-wave } \\
\text { ipalatinsk }\end{array}$ & $\begin{array}{l}\text { Irival } \\
\text { est. site. }\end{array}$ & & & & & & & & \\
\hline
\end{tabular}


following infornation is indicated: station name, origin time to. P-wave arrival time $t_{p}$ epicentral coordinates (latitude and longitude), hypocentral depth and magnitude.

in the second ine of the title the information for the channels ( $Z$, E-W or $N-S$ ) is indicated.

The following data are indicated: year, month, hour, minute, second; the name of the digital station, the digitization frequenoy; length of the record; the channel number: and the seismometer type.

3.2. Seismograms obtained by the station instailed in the Muyunkurn desert area.

Two records of two underground nuolear explosions, one from the Sernipalatinsk test site and an industrial explosion (from the west Siberia region), and also one record of an earthouake from the northern Tien shan region were picked out (Table 3.3). It is interesting that both explosions indicated have also been recorded by the Talgar station (ASS), see Table 3.1 .

The seismograms are three-component, and the digitization î requenoy is $25 \mathrm{~Hz}$.

\title{
3.3. Seismograms recorded by the small-aperture array.
}

\begin{abstract}
Unfortunately, during the time of operation of the snall-aperture array, neither nuolear explosions nor
\end{abstract}




\section{. .}

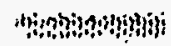

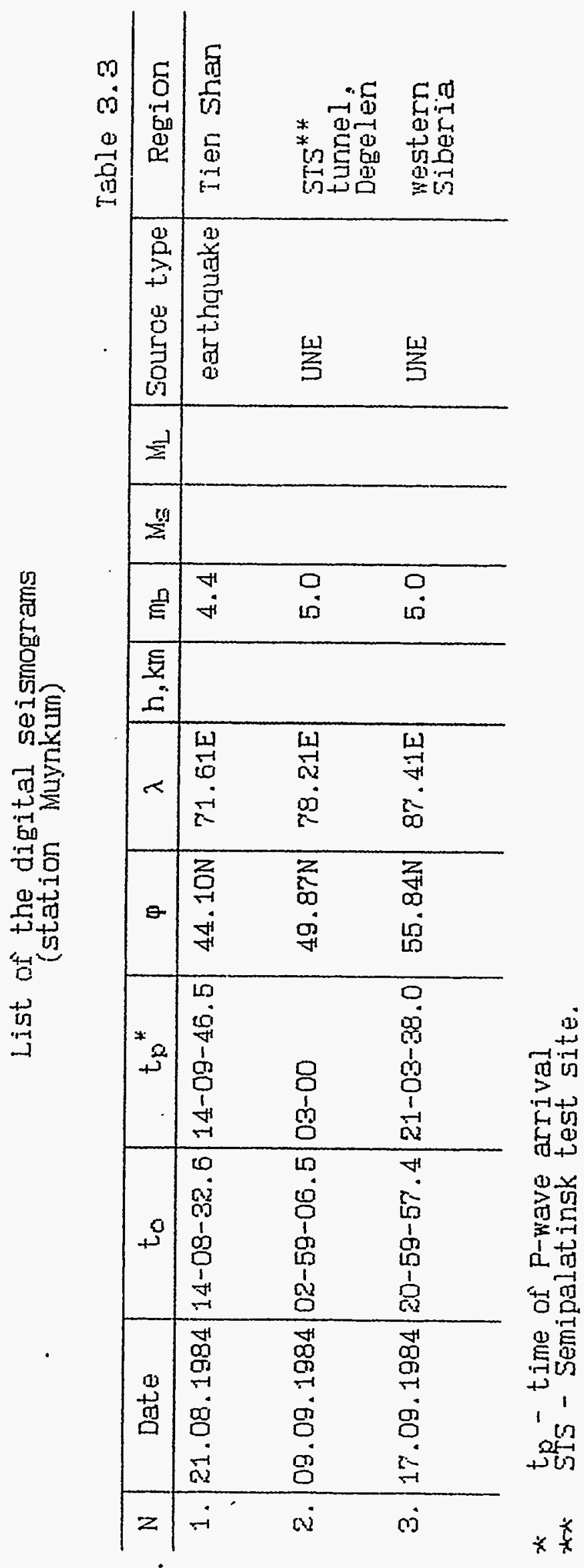




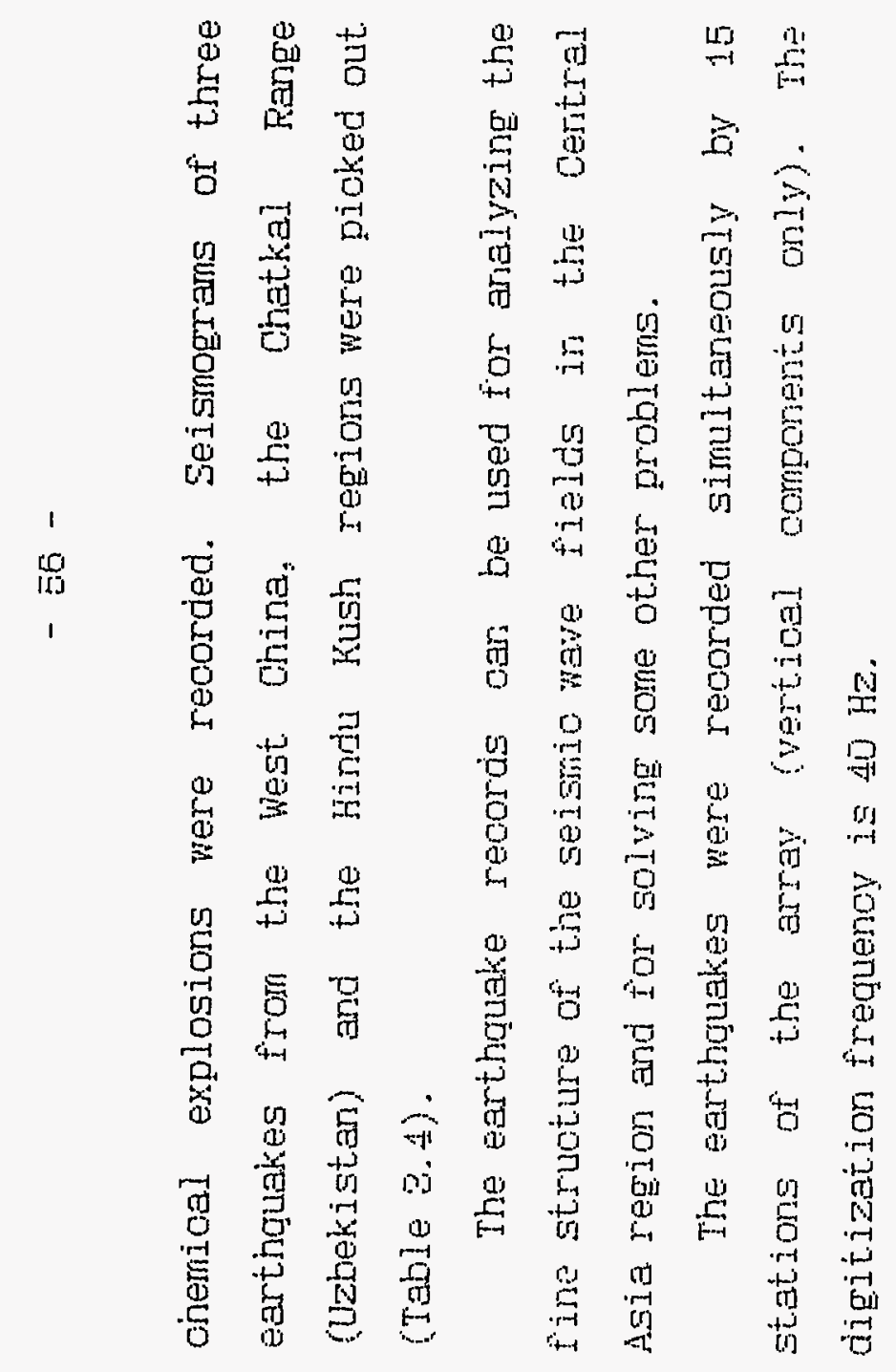


List of the digital seismograms (small-aperture array)

Table 3.4

\begin{tabular}{|c|c|c|c|c|c|c|c|c|c|c|c|}
\hline $\mathrm{N}$ & Date & $t_{0}$ & $t_{p}^{*}$ & $\varphi$ & $\lambda$ & $\mathrm{h}, \mathrm{km}$ & $m_{b}$ & $M=$ & $M_{L}$ & Source type & Region \\
\hline 1. & 16.10 .1987 & $18-30-45.7$ & & $44.19 \mathrm{~N}$ & $82.72 E$ & 3 & 4.6 & & & earthquake & China \\
\hline 2. & 18.10.1987 & $03-13-46.4$ & & $36.24 \mathrm{~N}$ & $69.58 \mathrm{E}$ & 3 & 5.1 & & & earthquake & Hindu Kush \\
\hline 3. & $18.10-198 ?$ & $07-01-14.0$ & & $42.30 \mathrm{~N}$ & $69.90 \mathrm{E}$ & & 4.1 & & & earthquake & Chatcal \\
\hline
\end{tabular}

$* t_{p}$ - time of P-wave arrival 


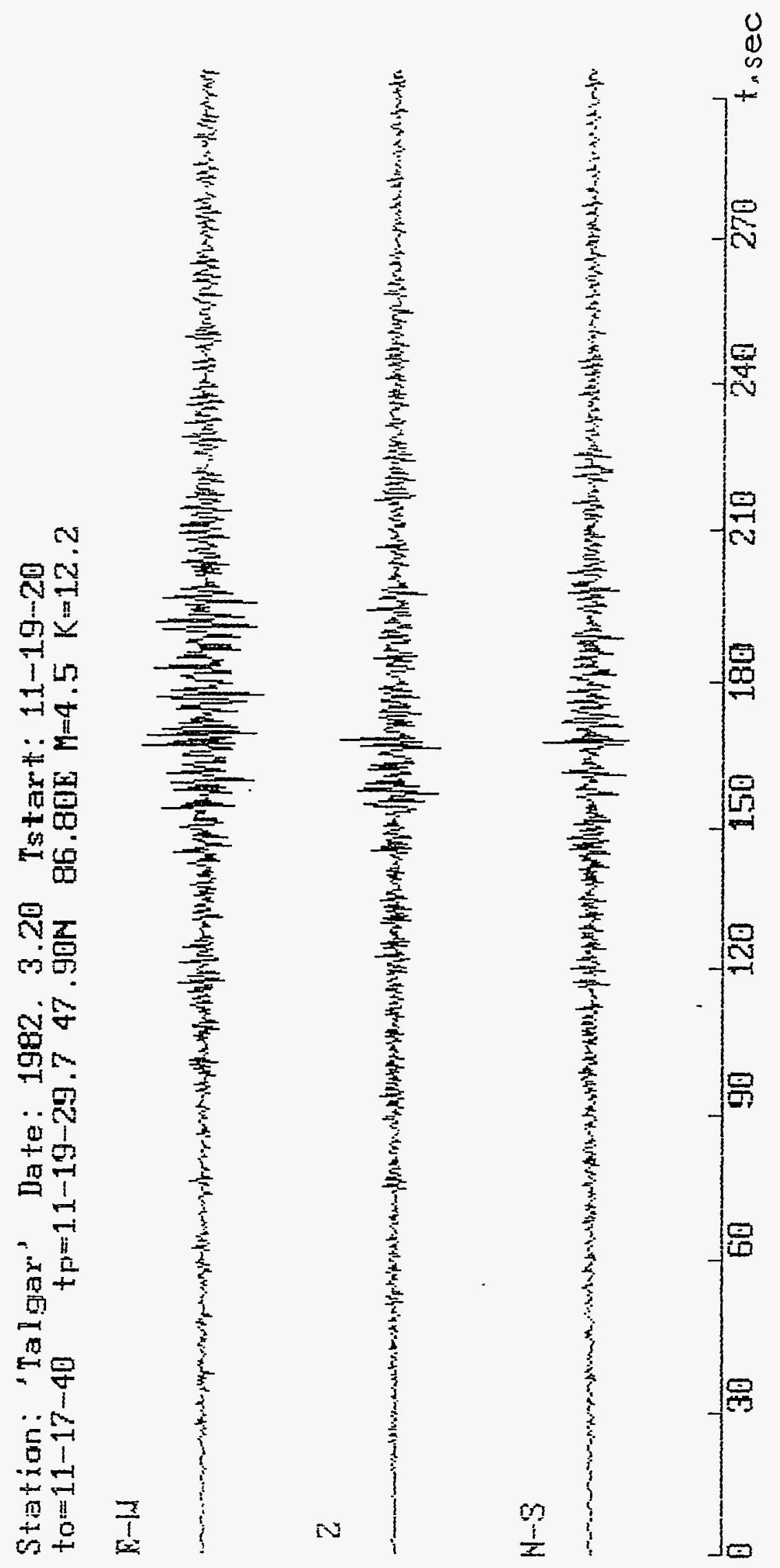




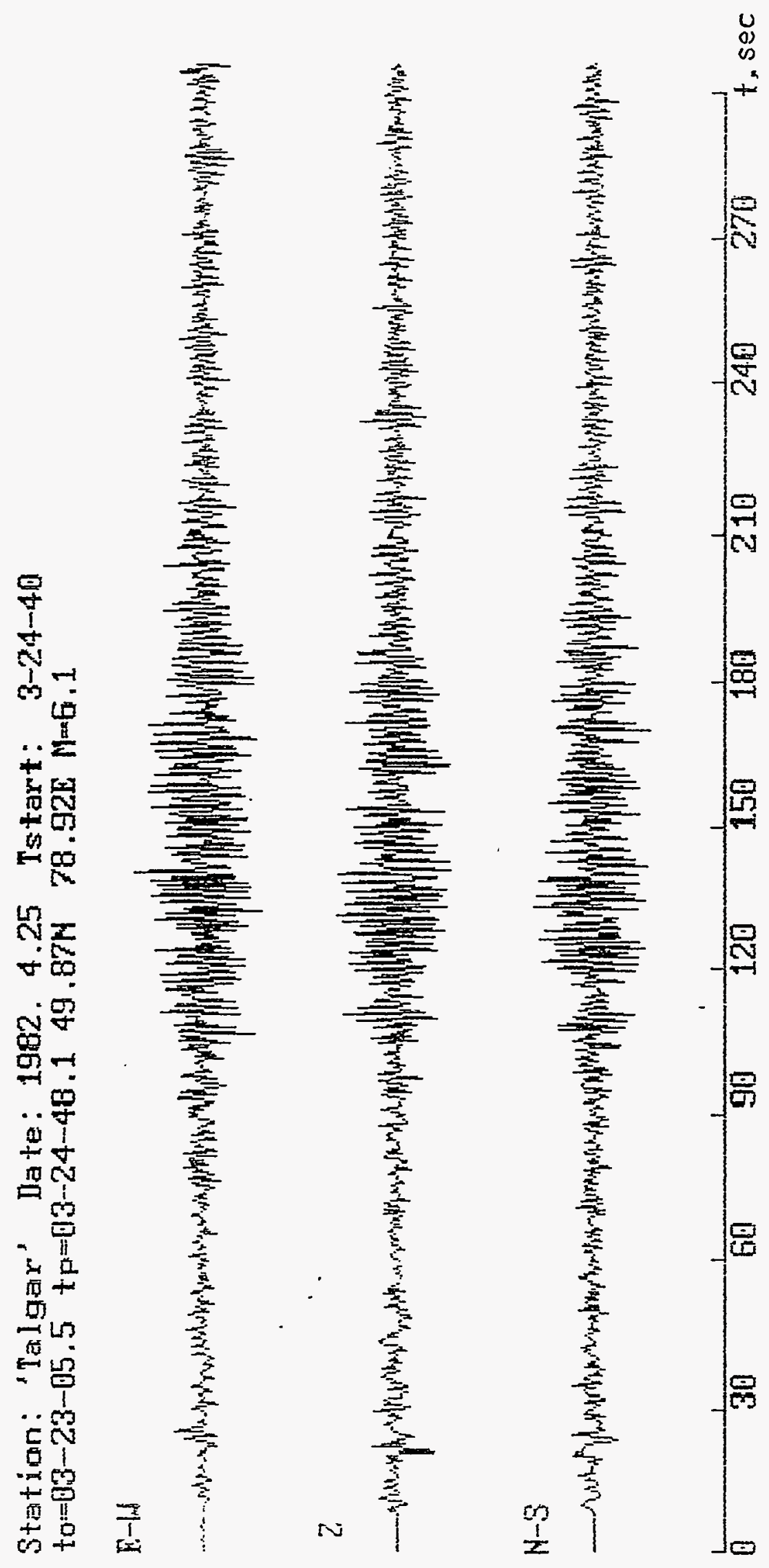



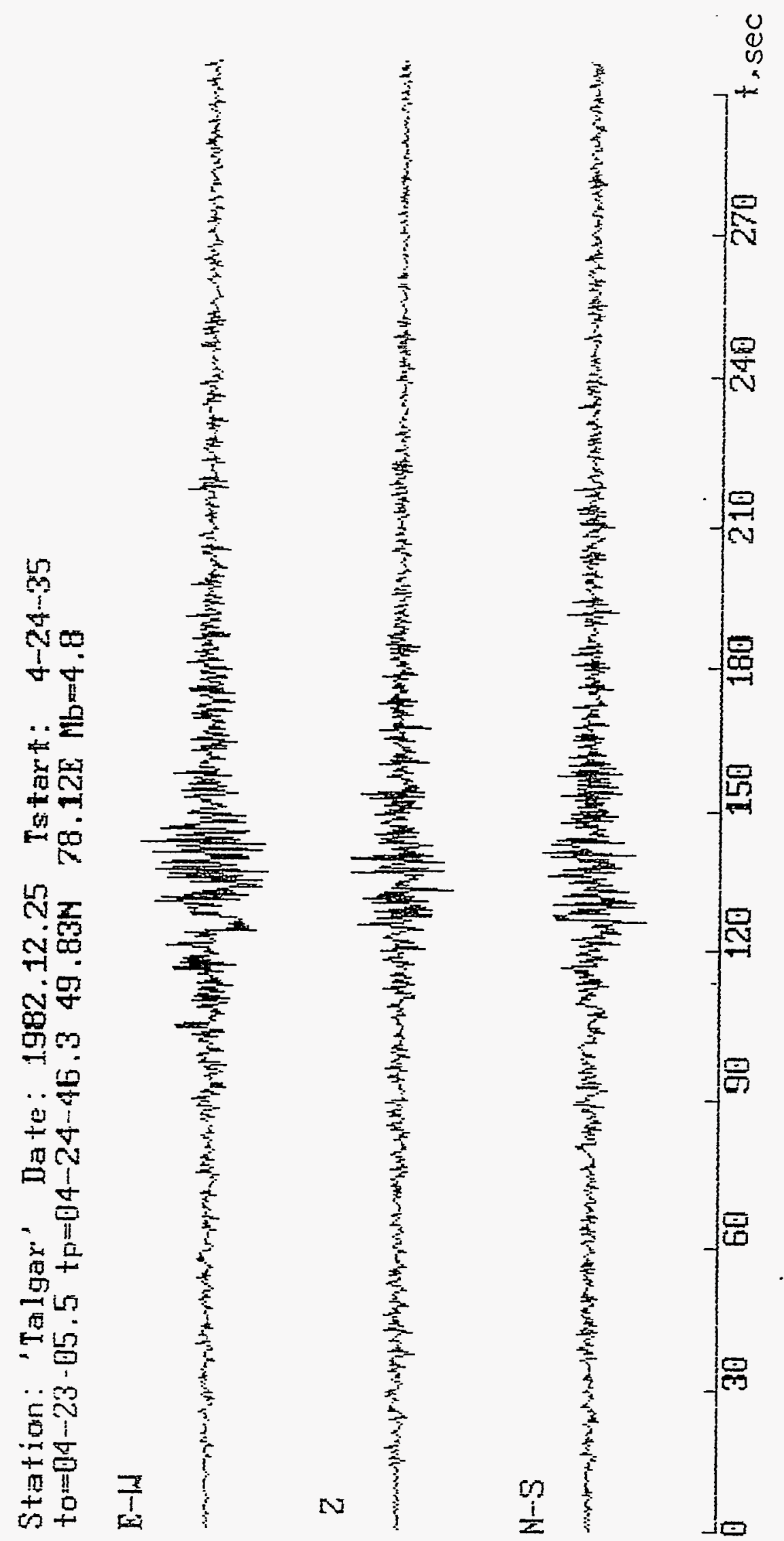


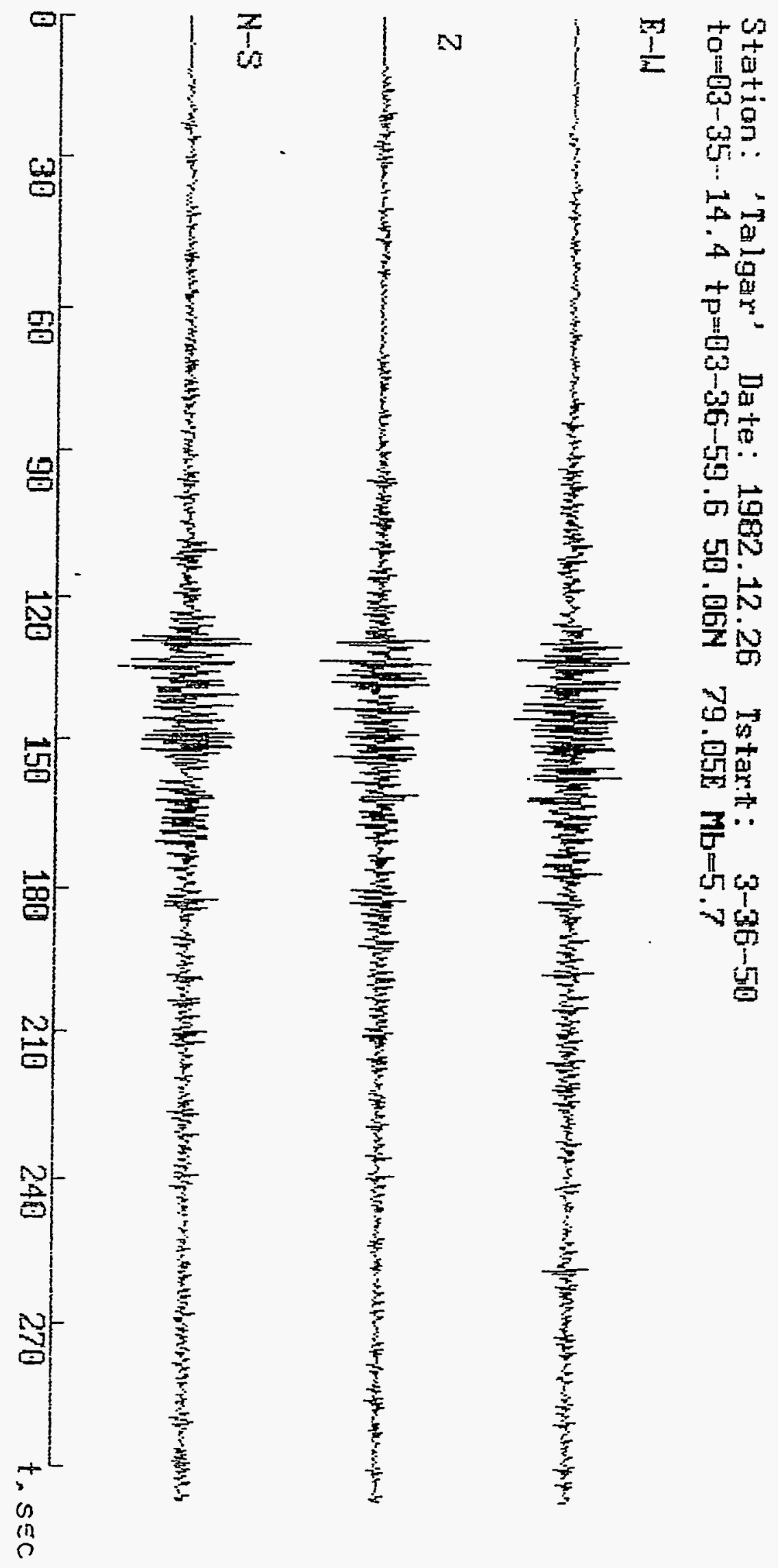

an

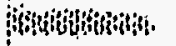

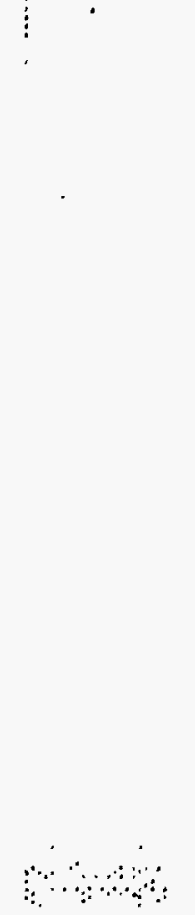



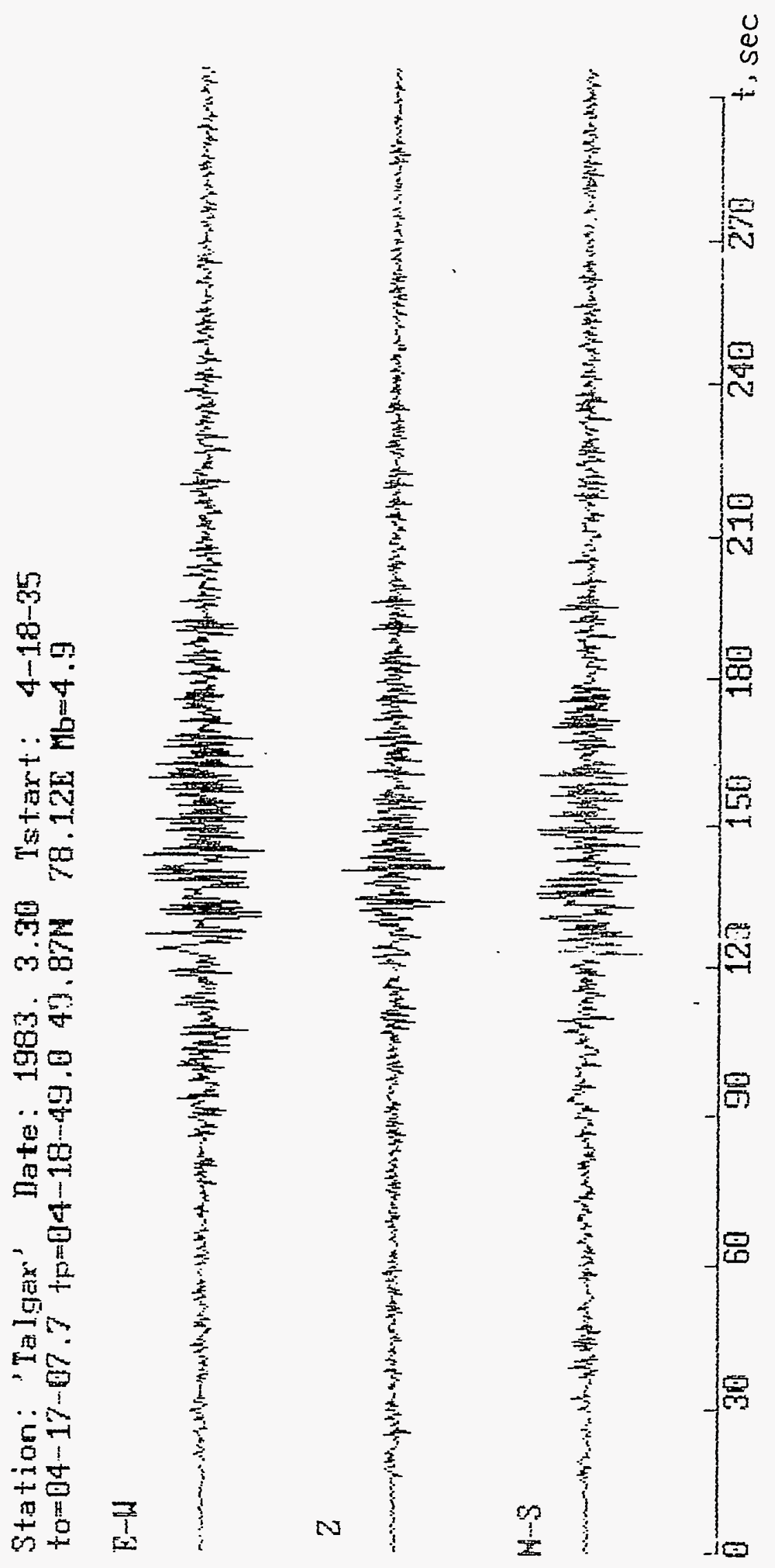
H

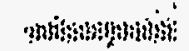

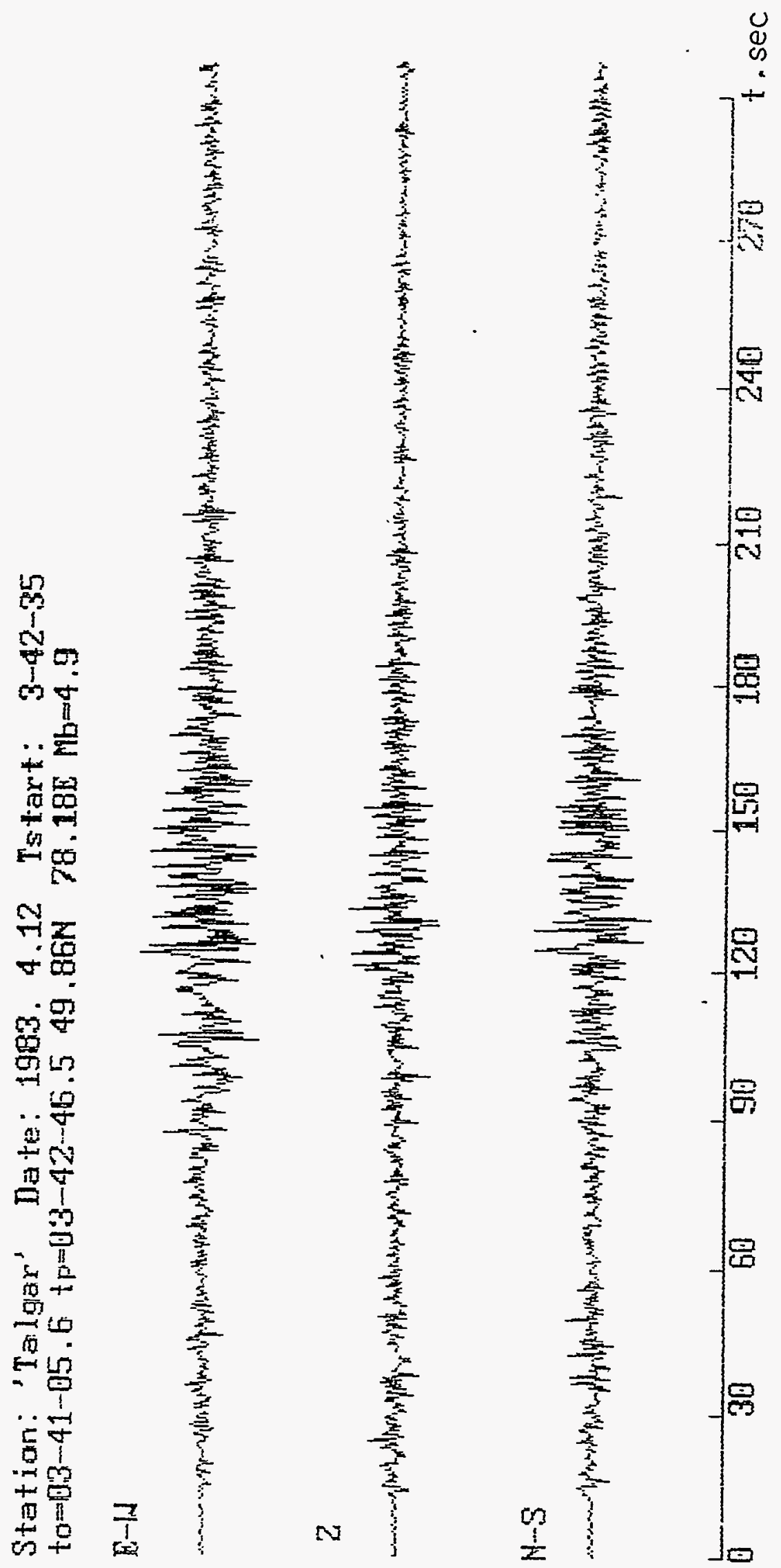




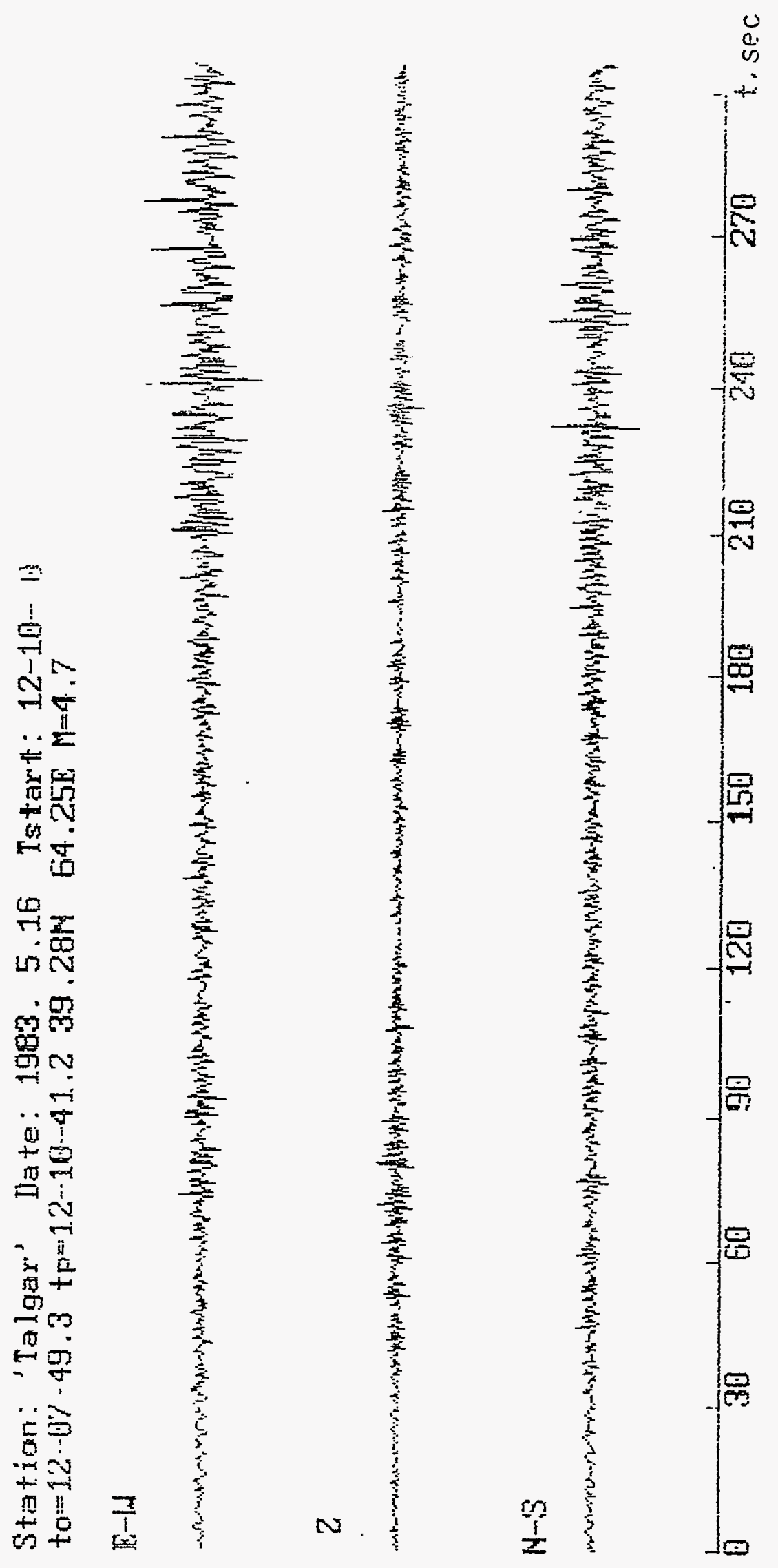




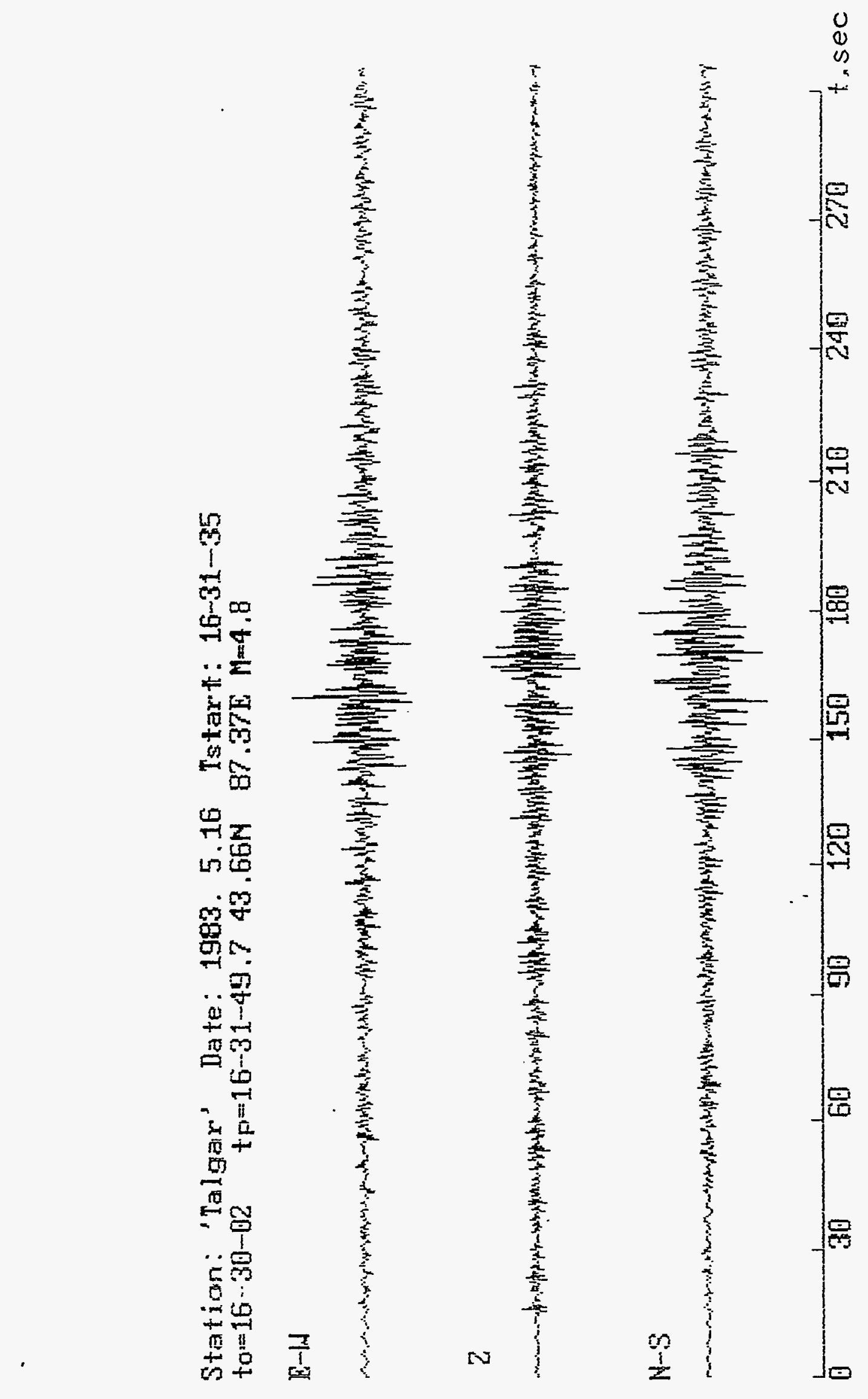



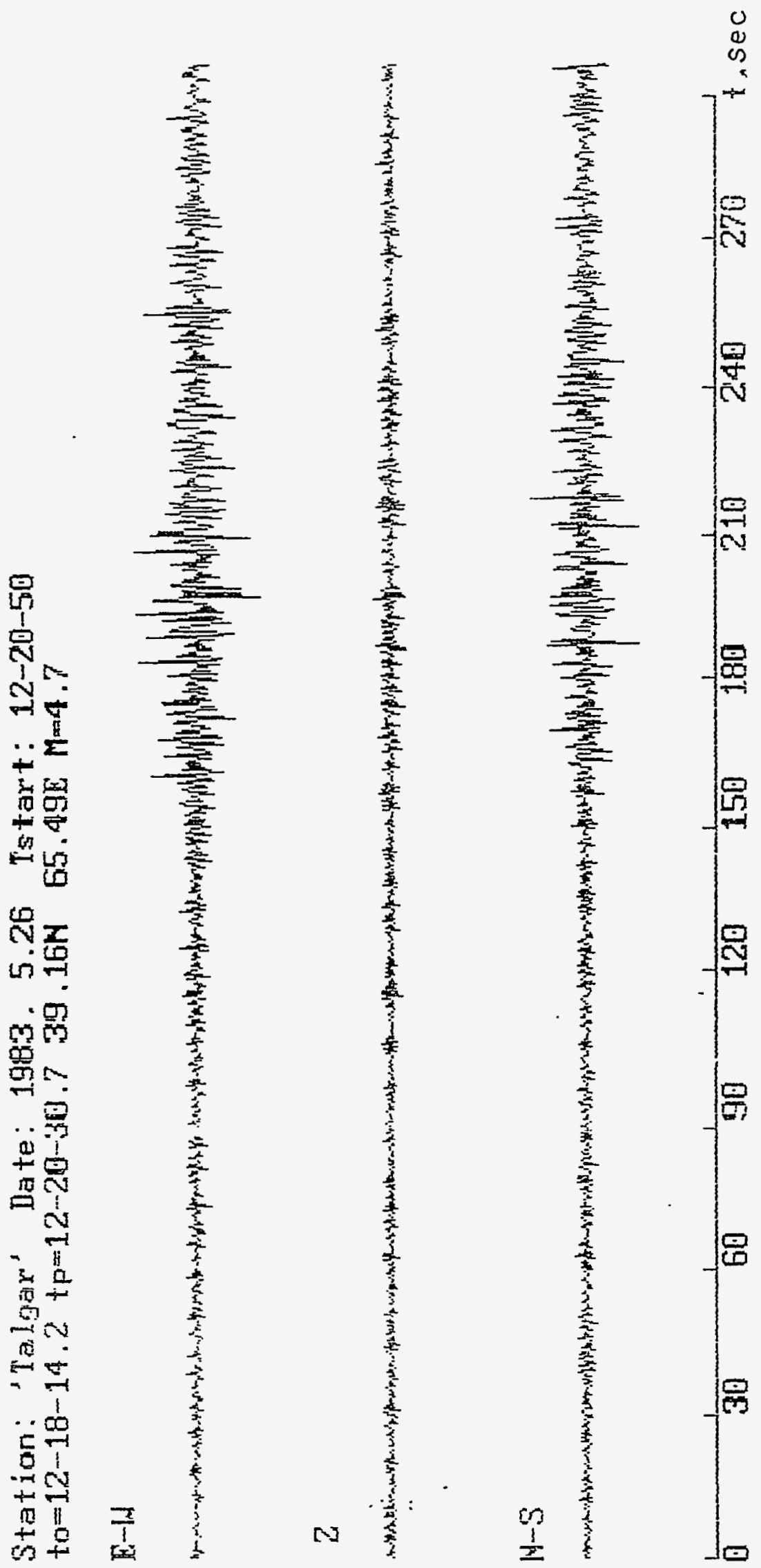

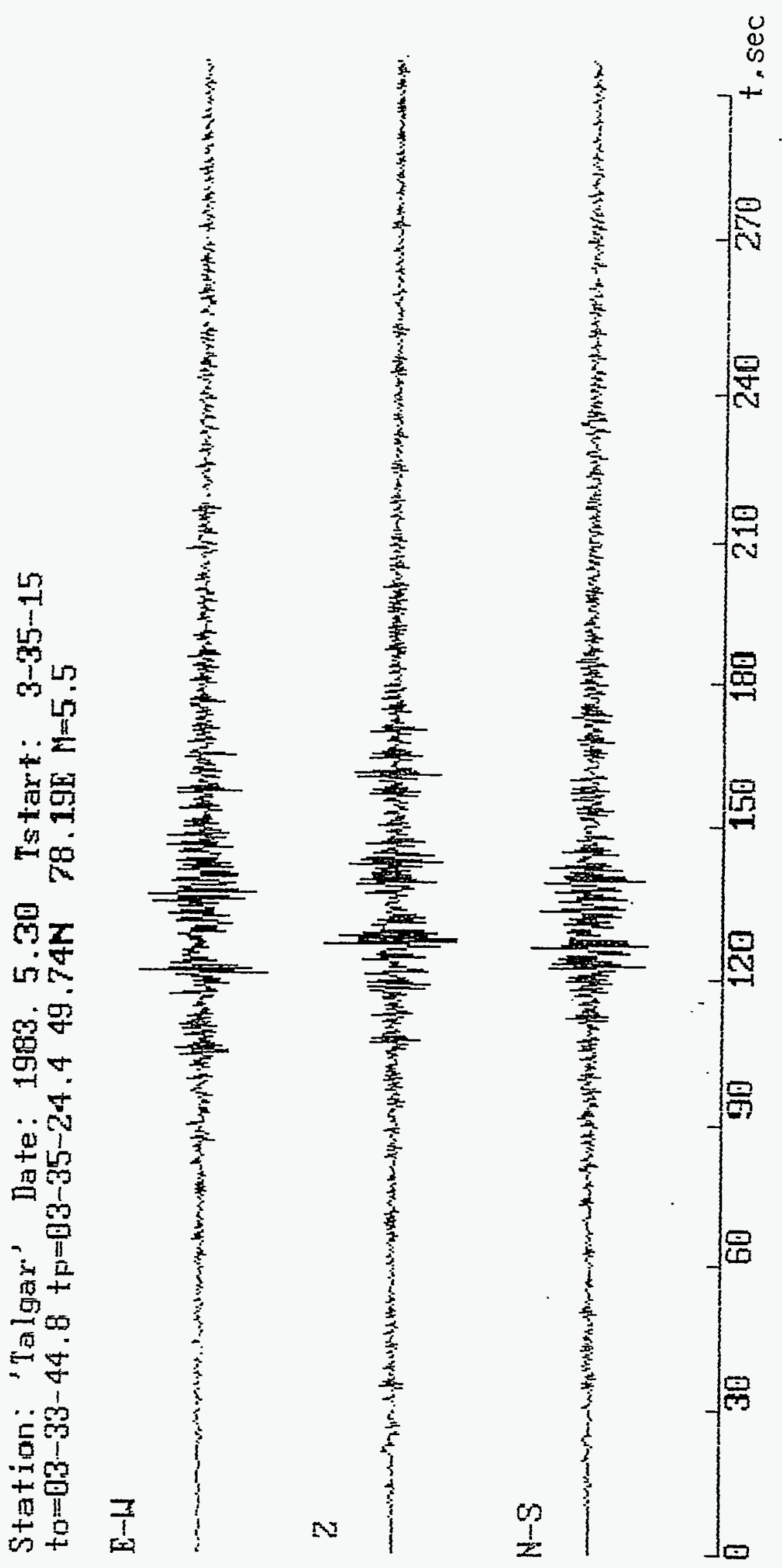

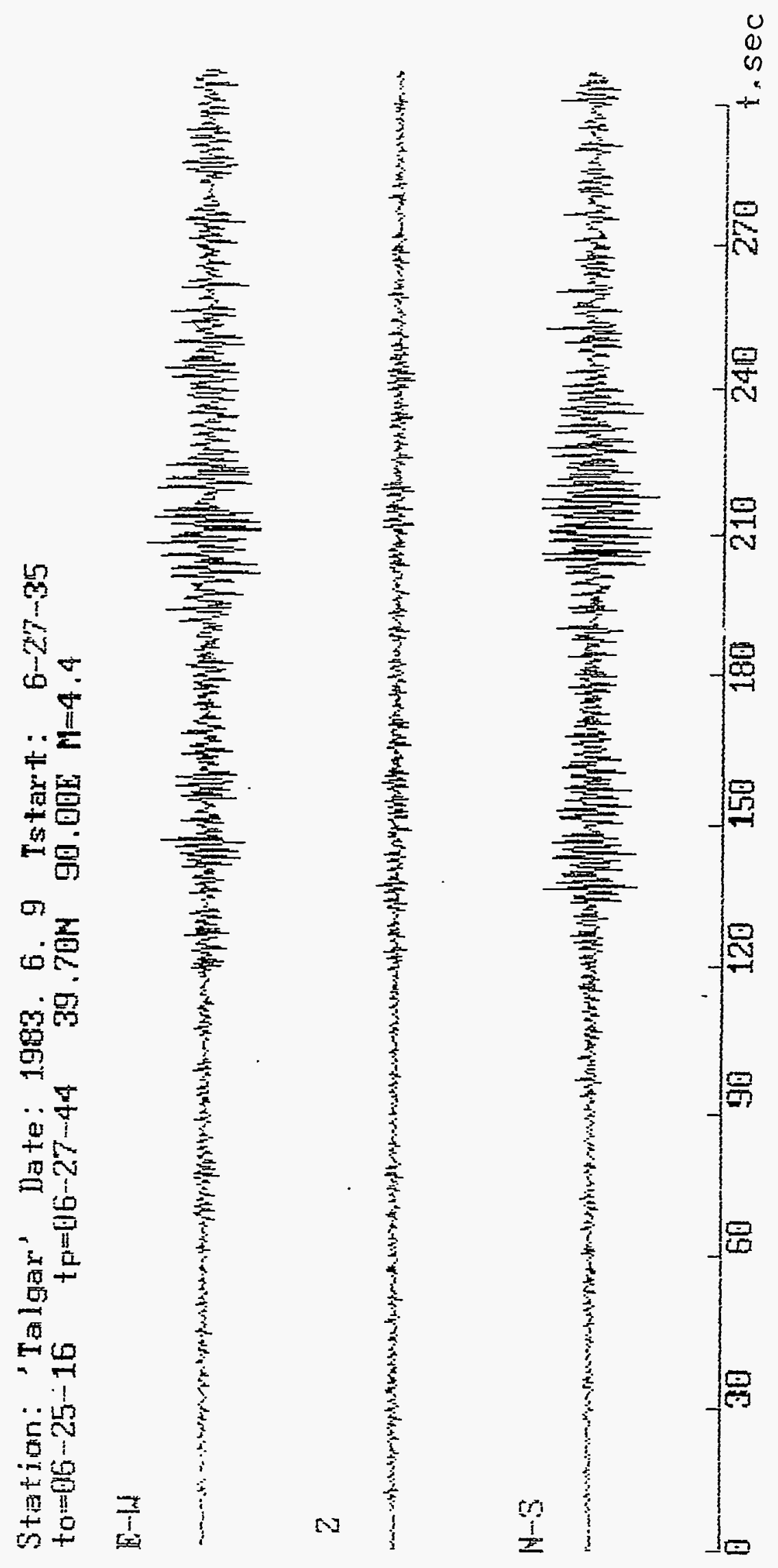


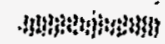

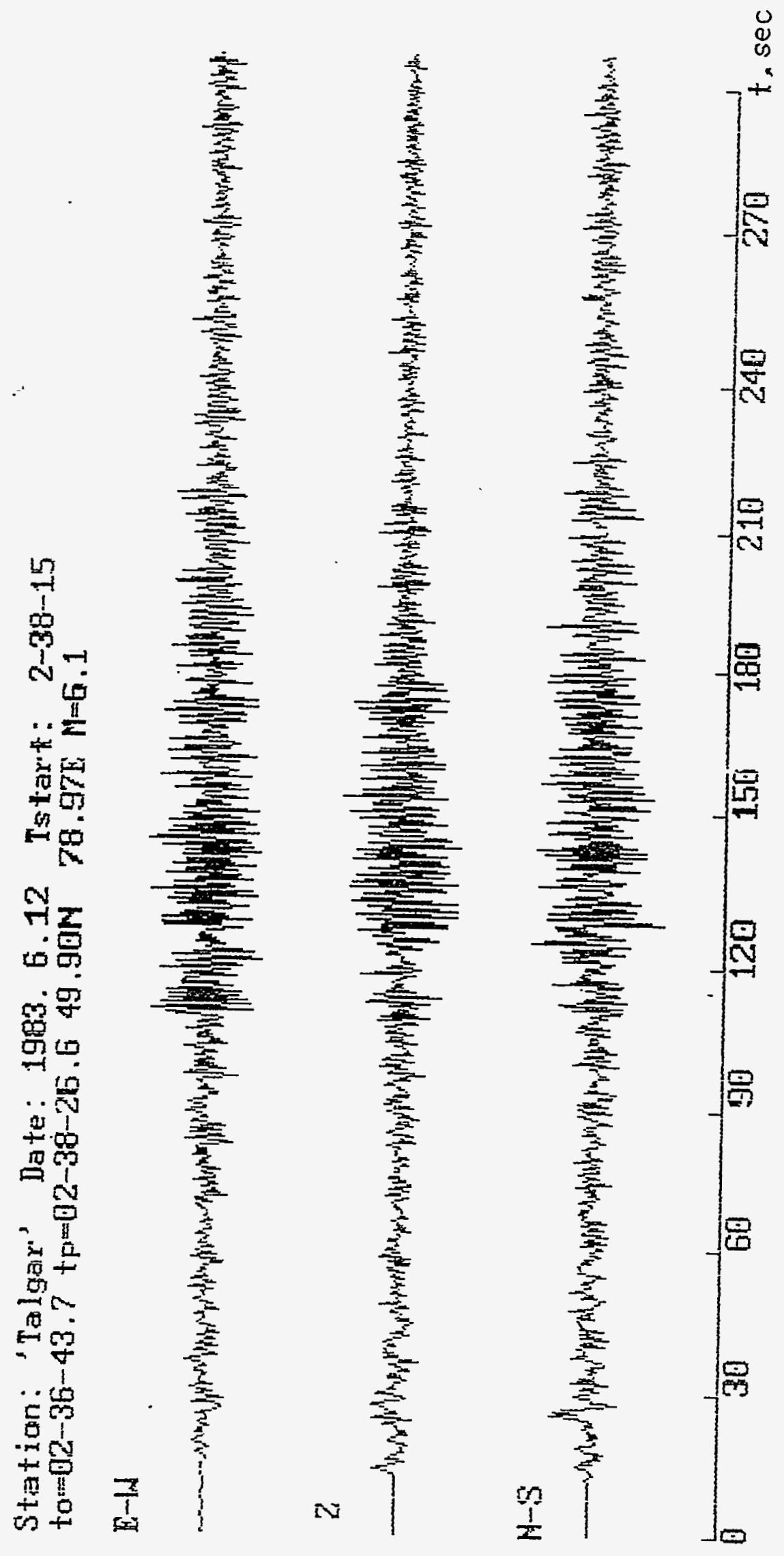



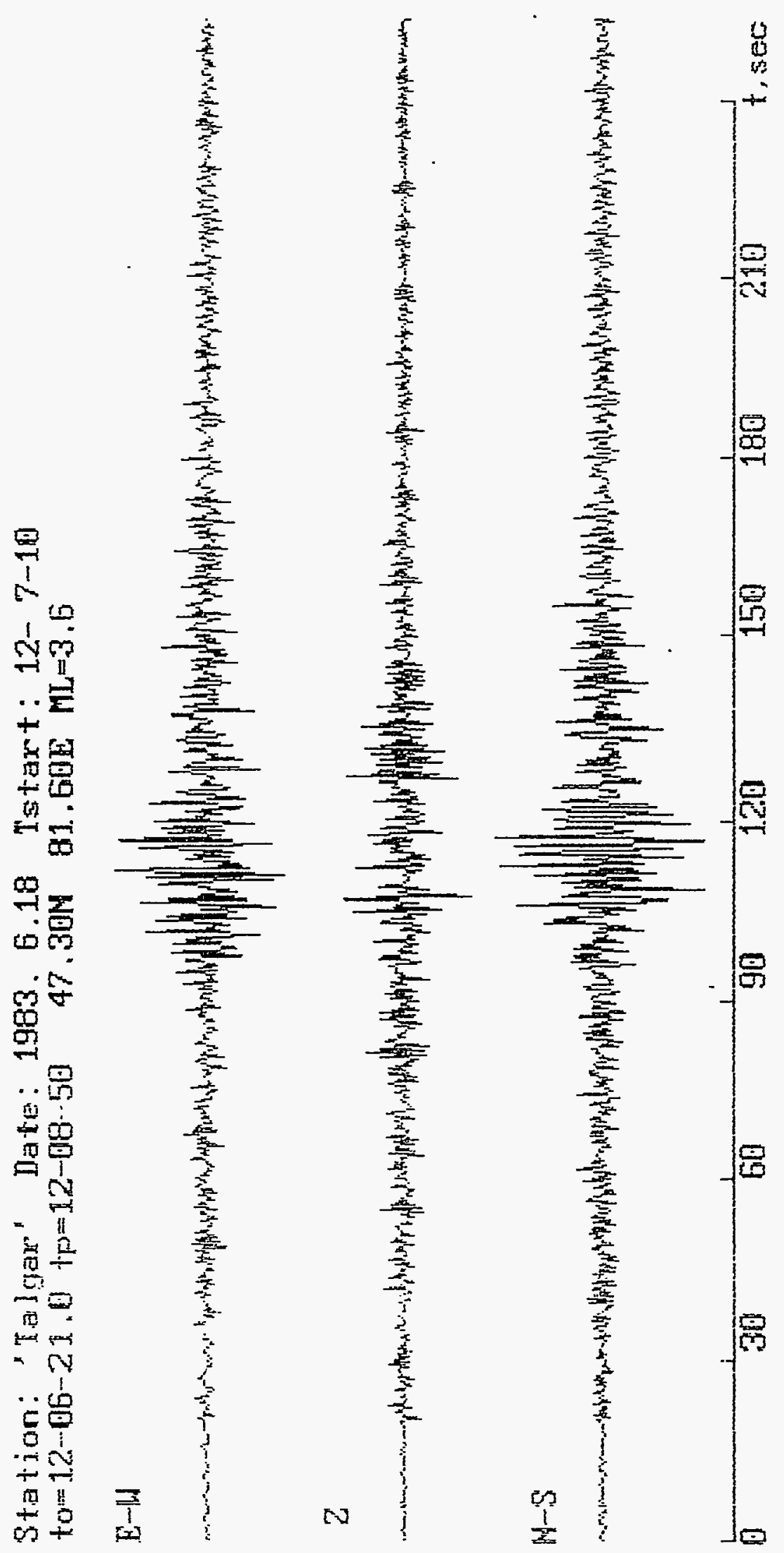

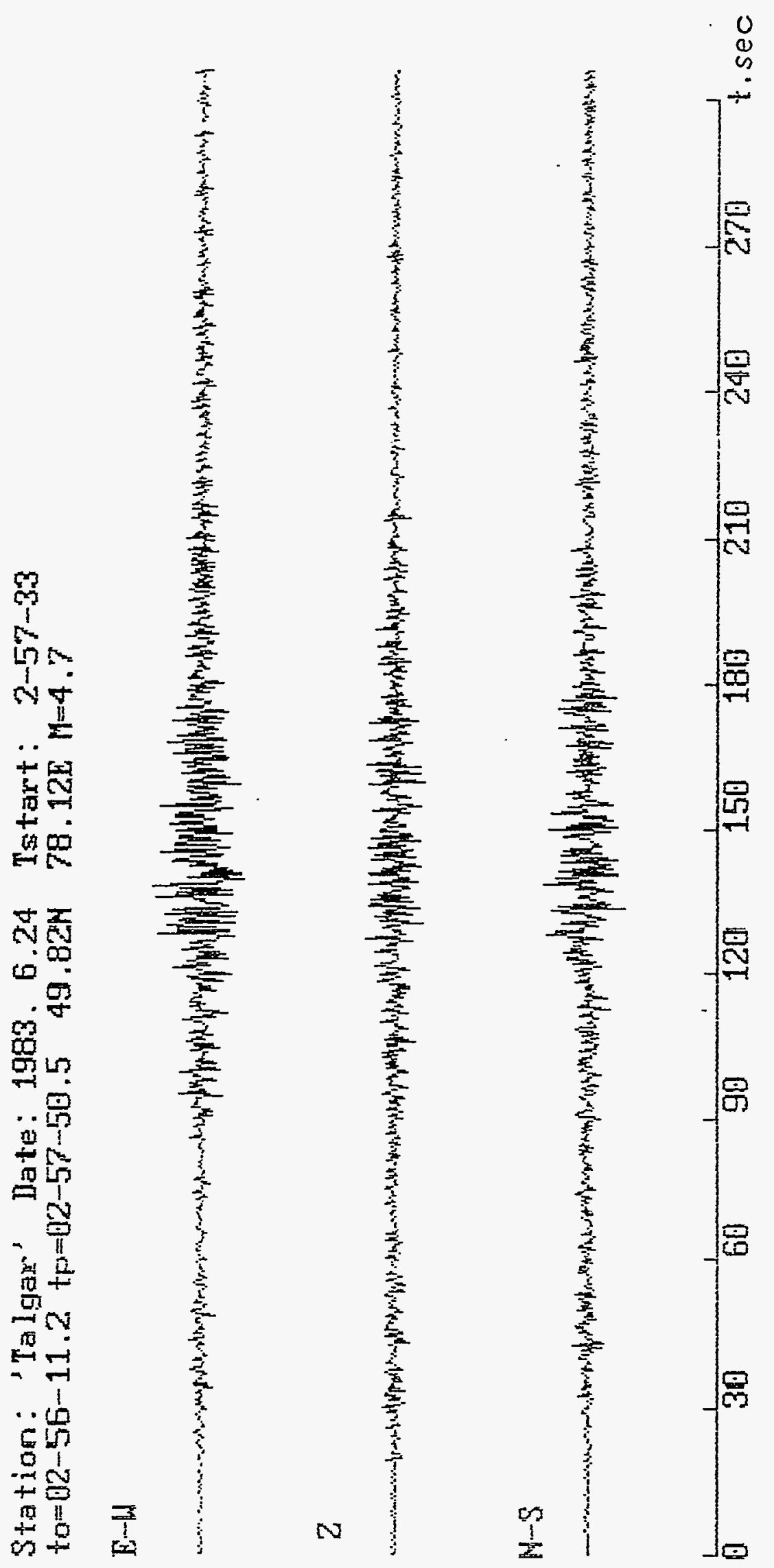

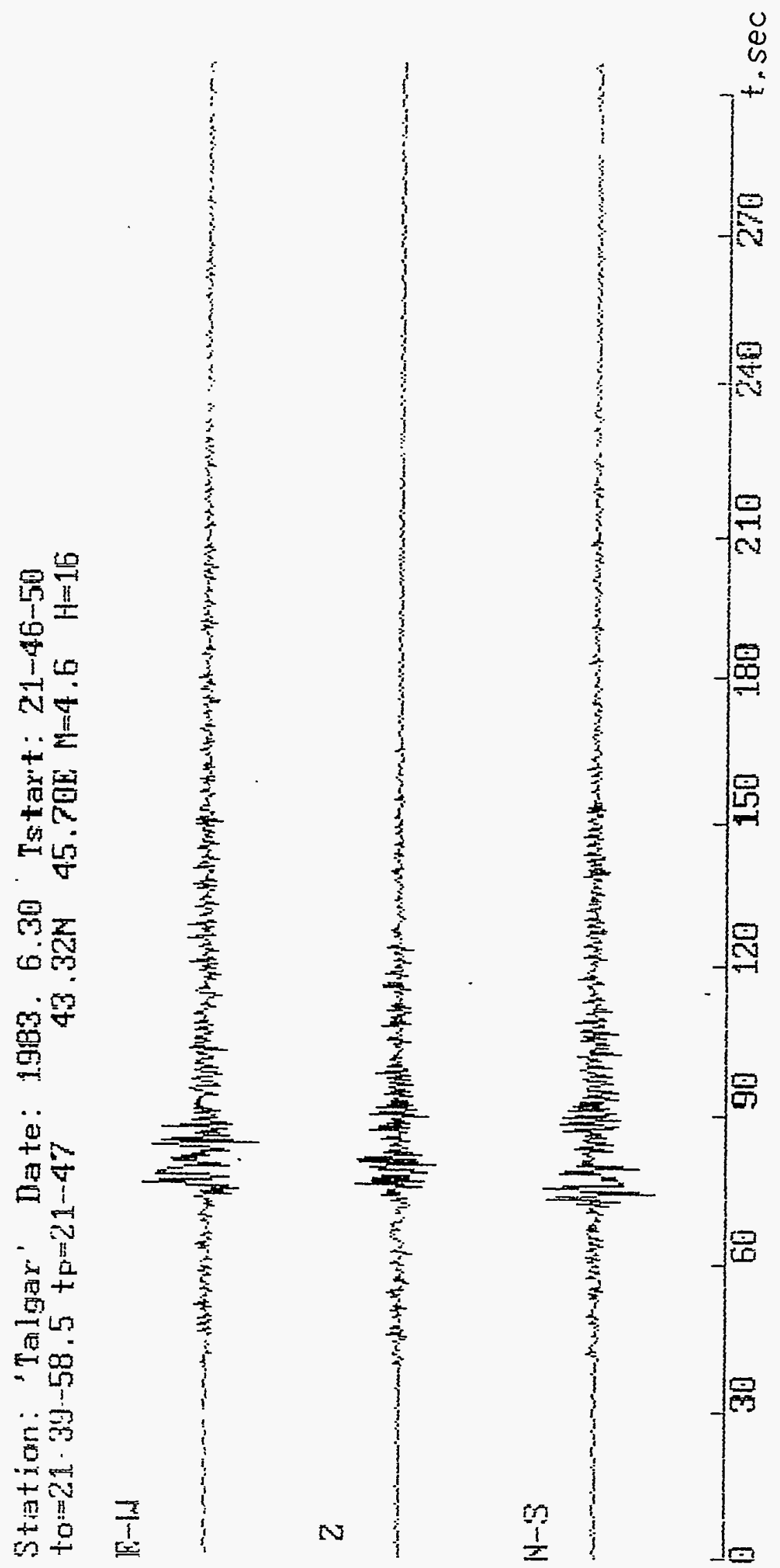

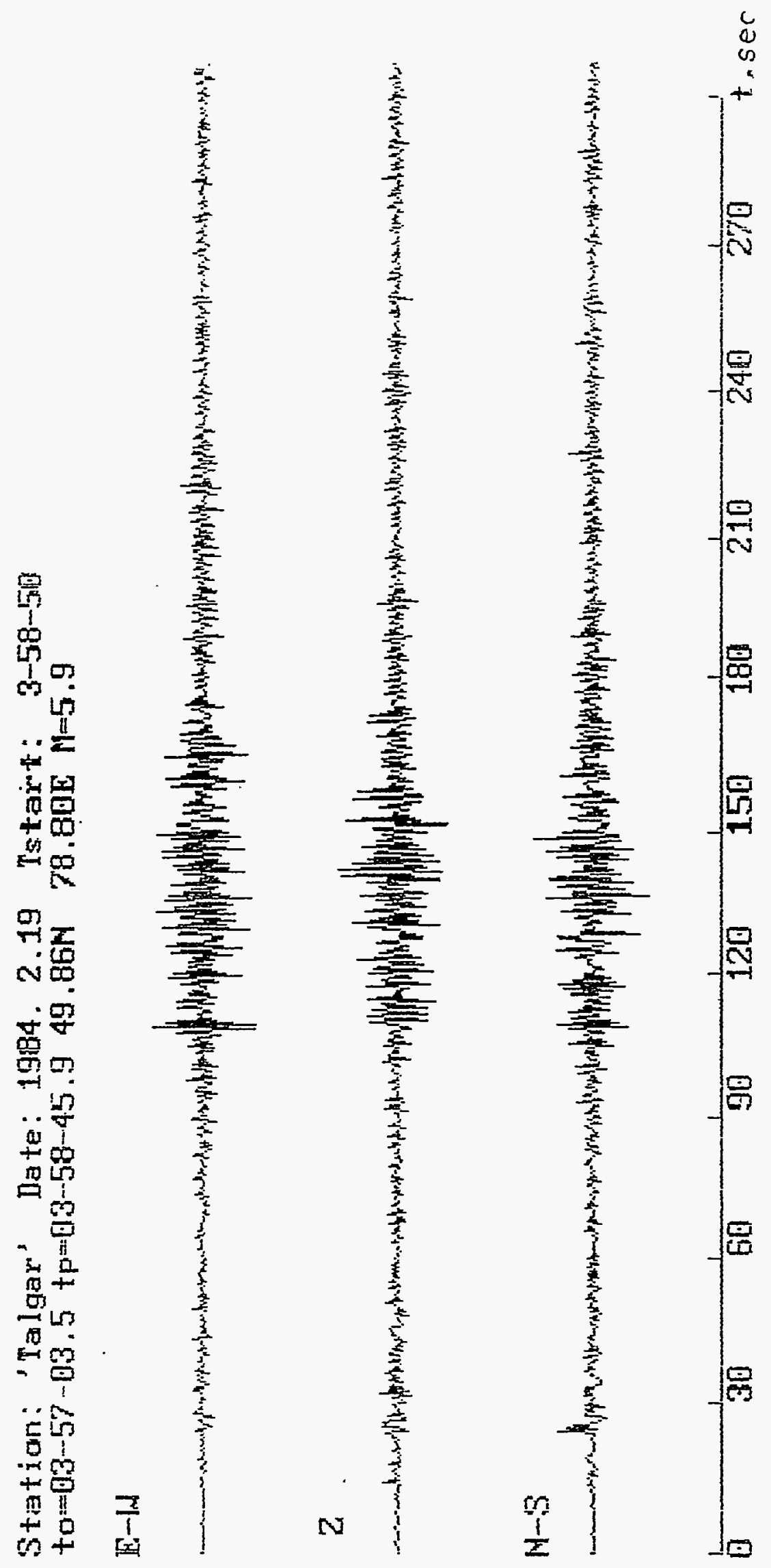


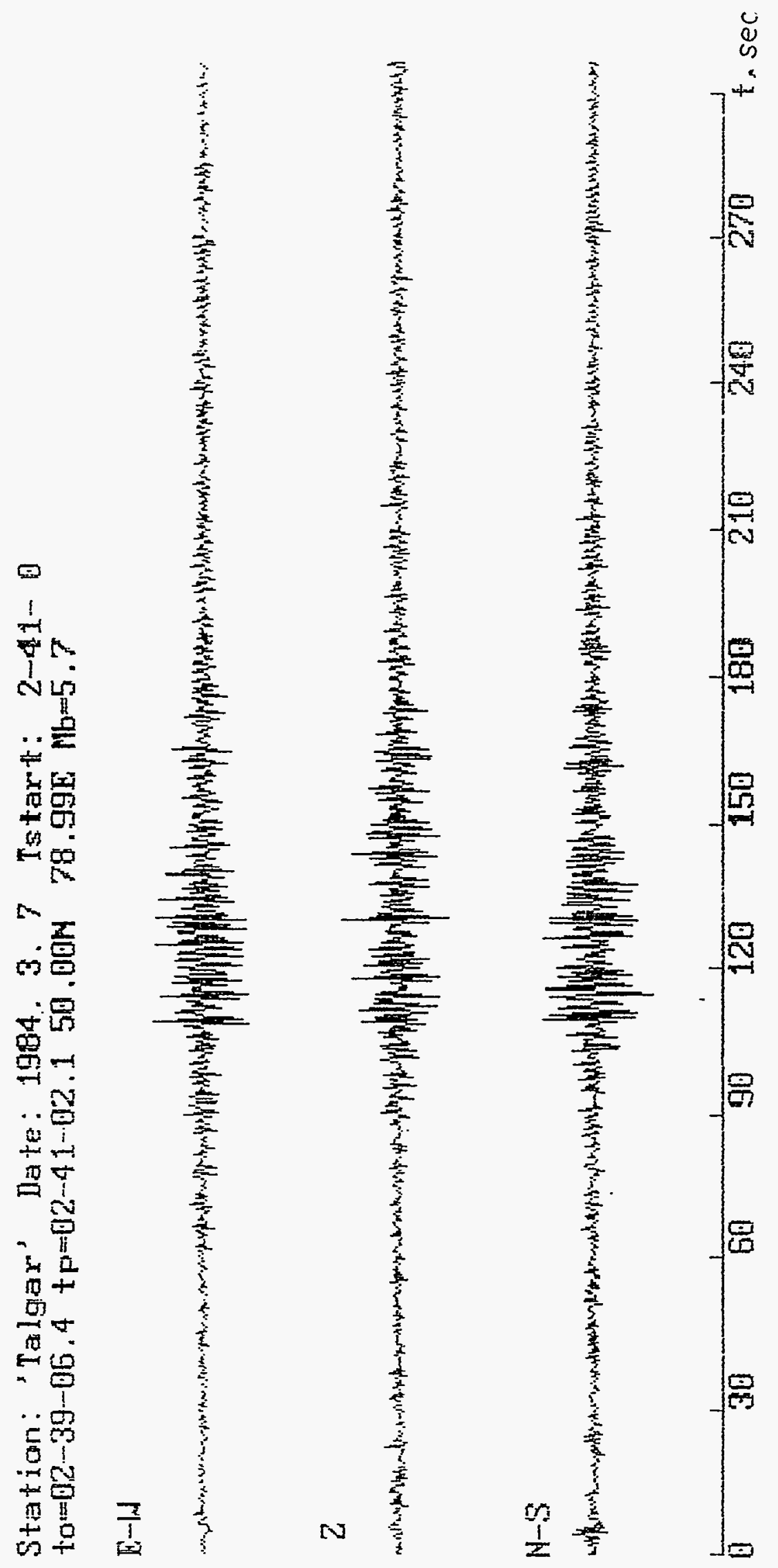




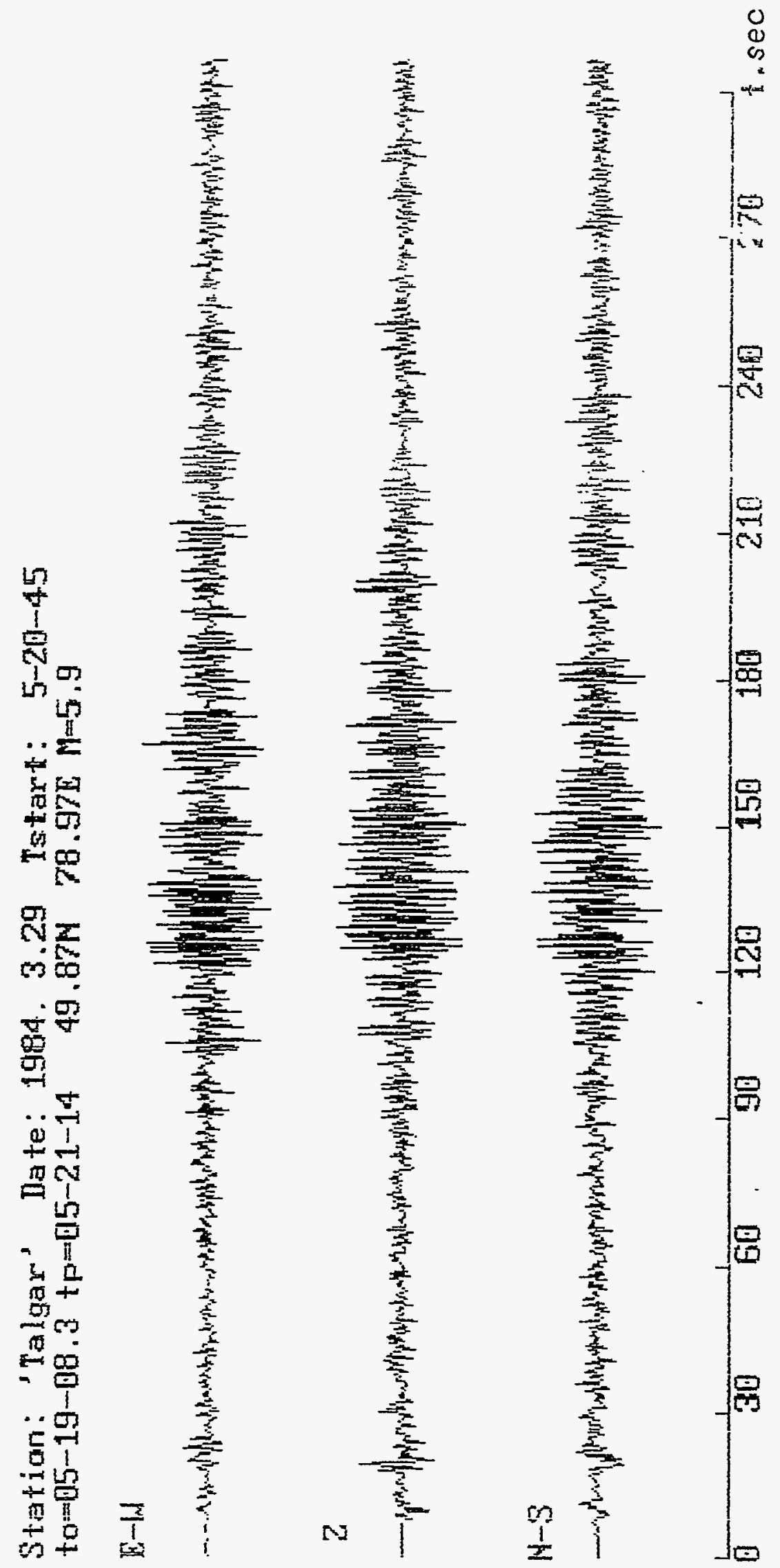



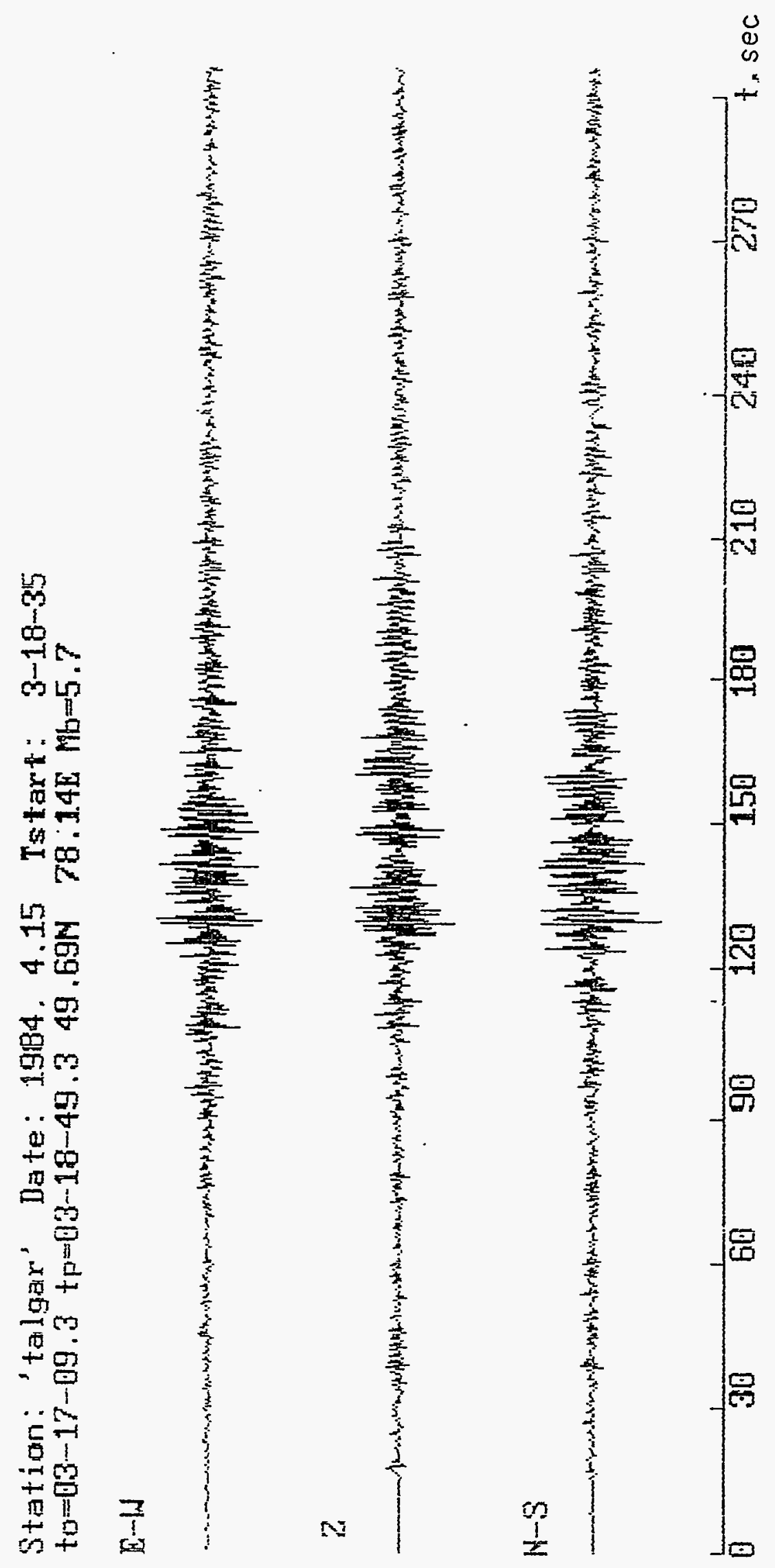

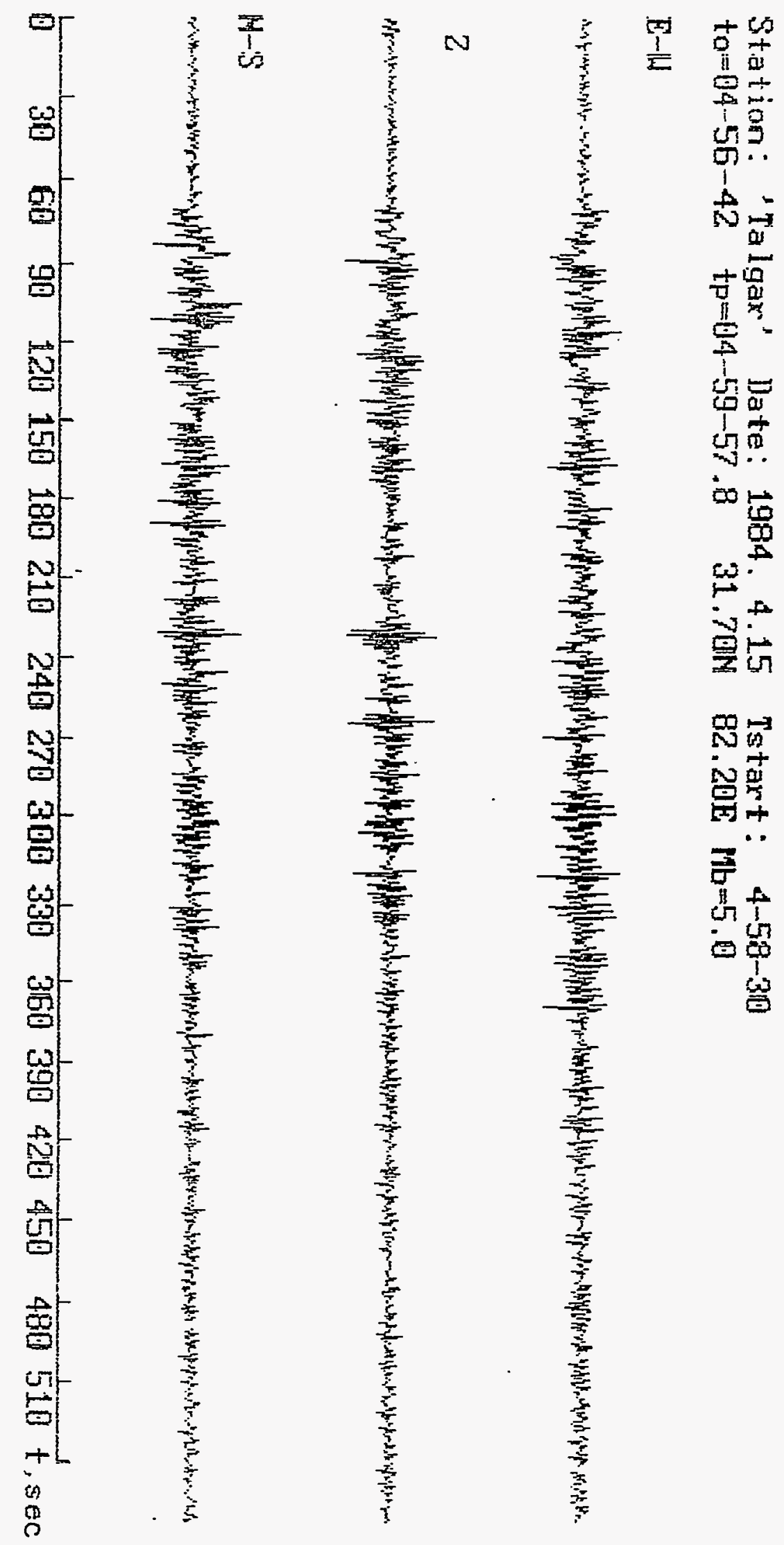

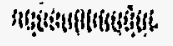

(s) 6 : 

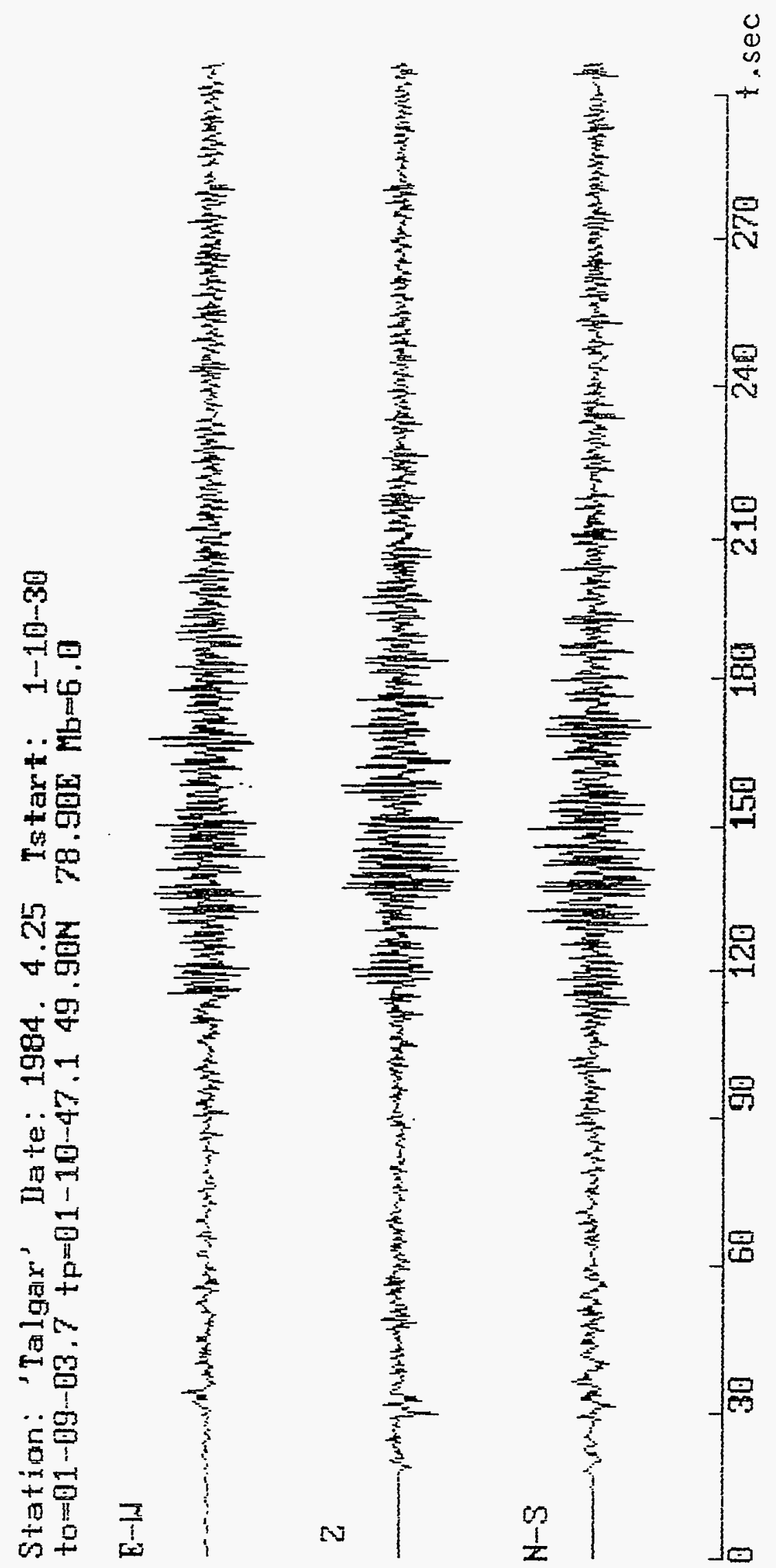


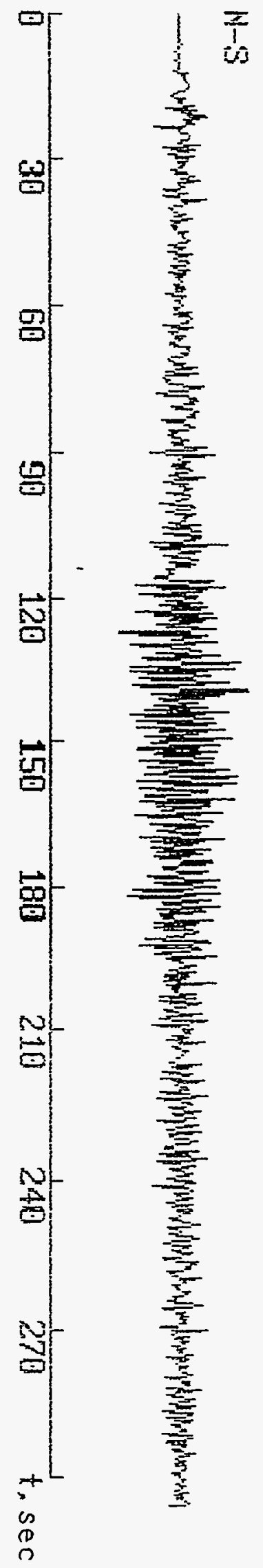

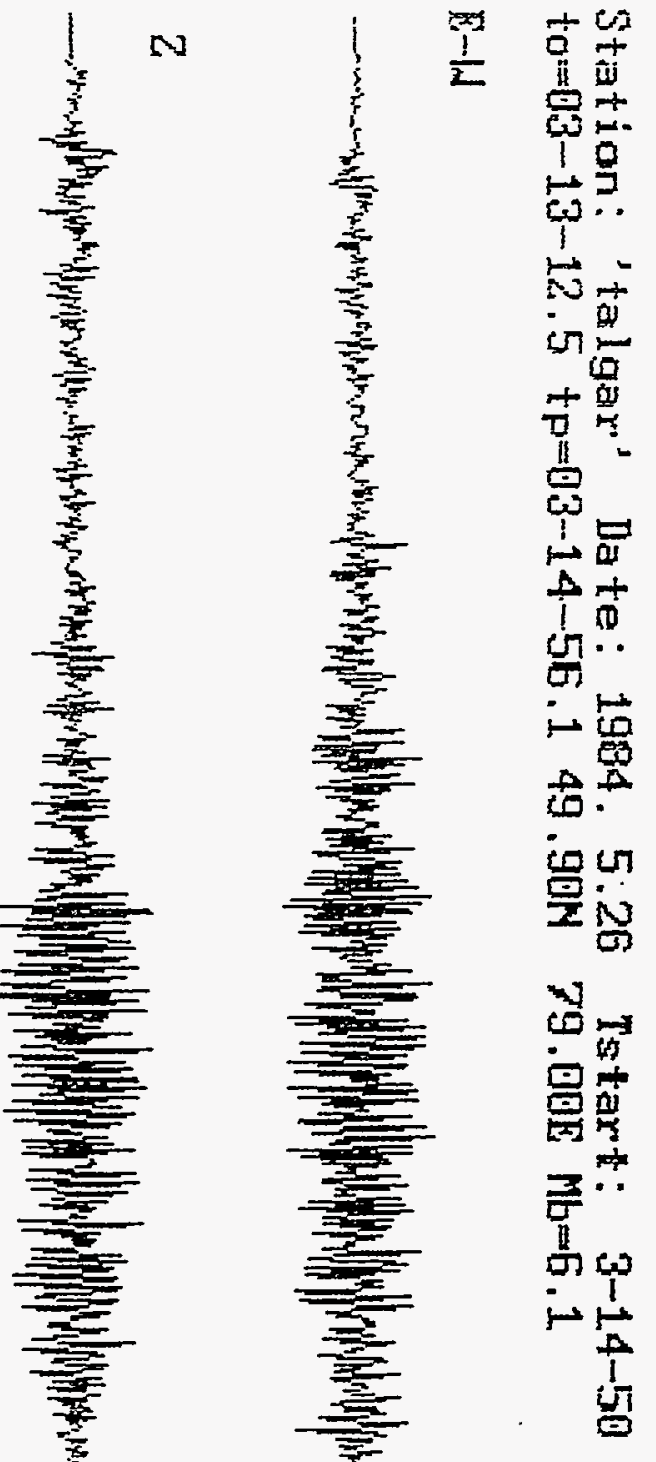

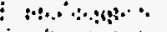

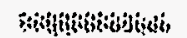




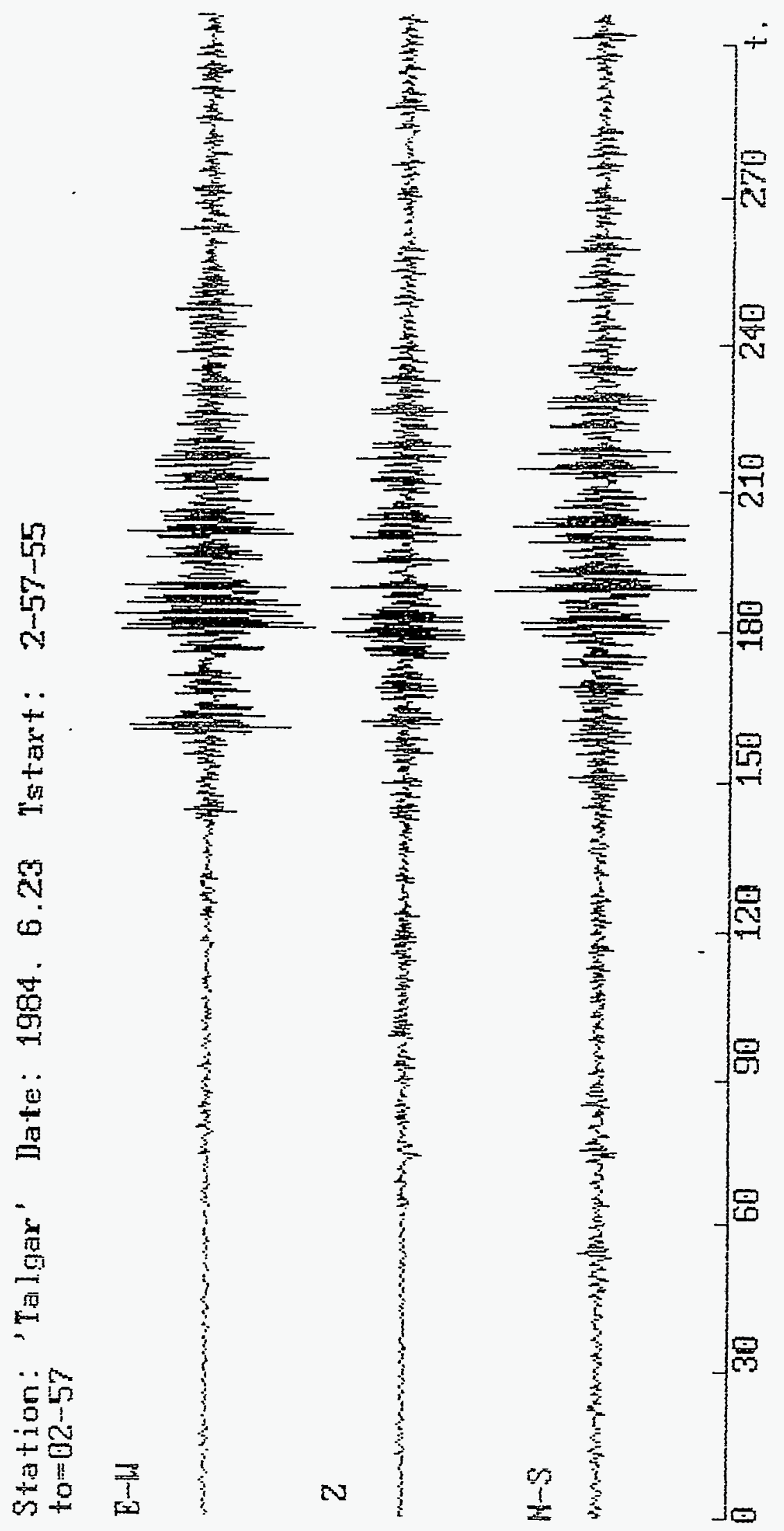




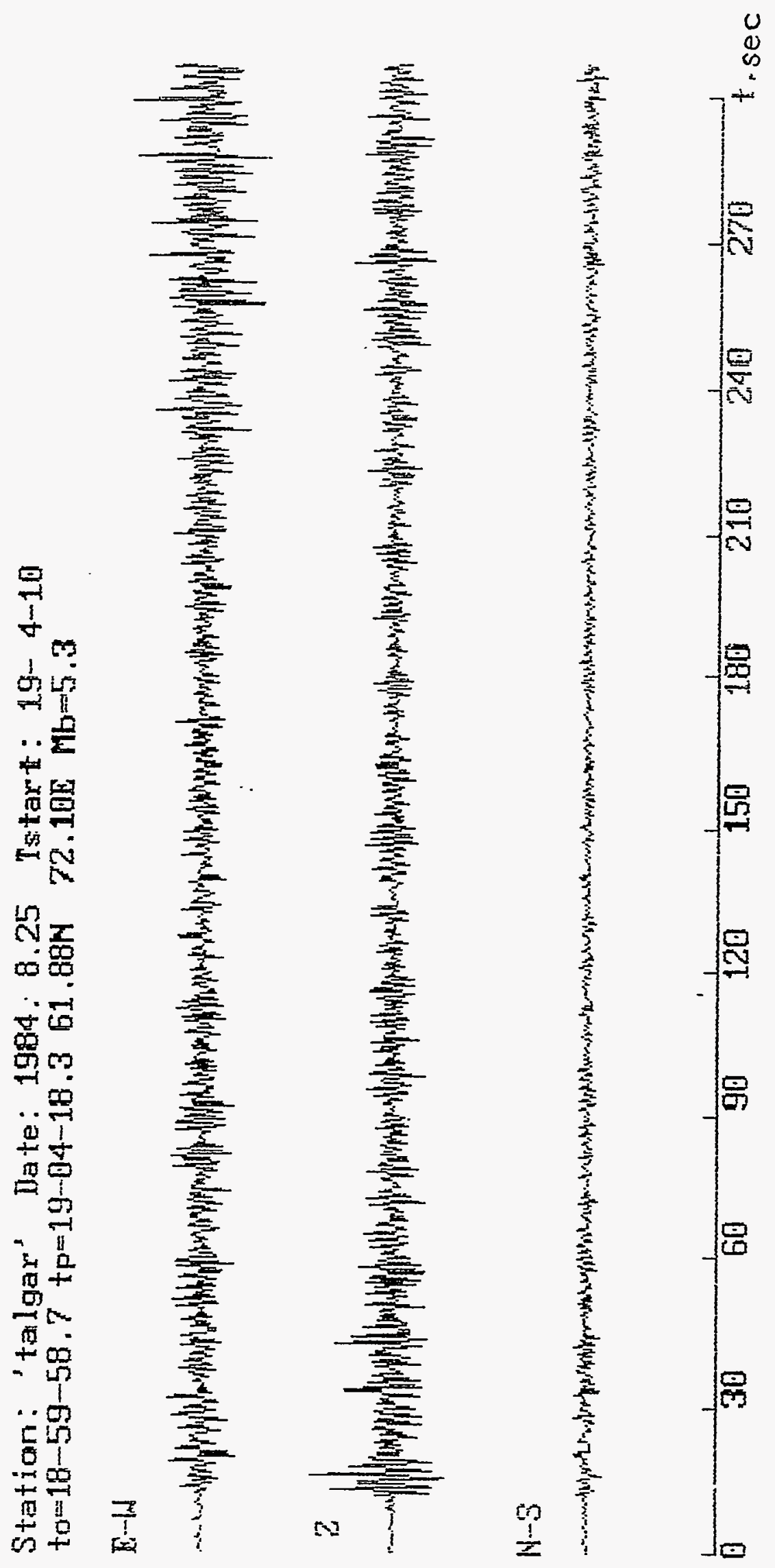



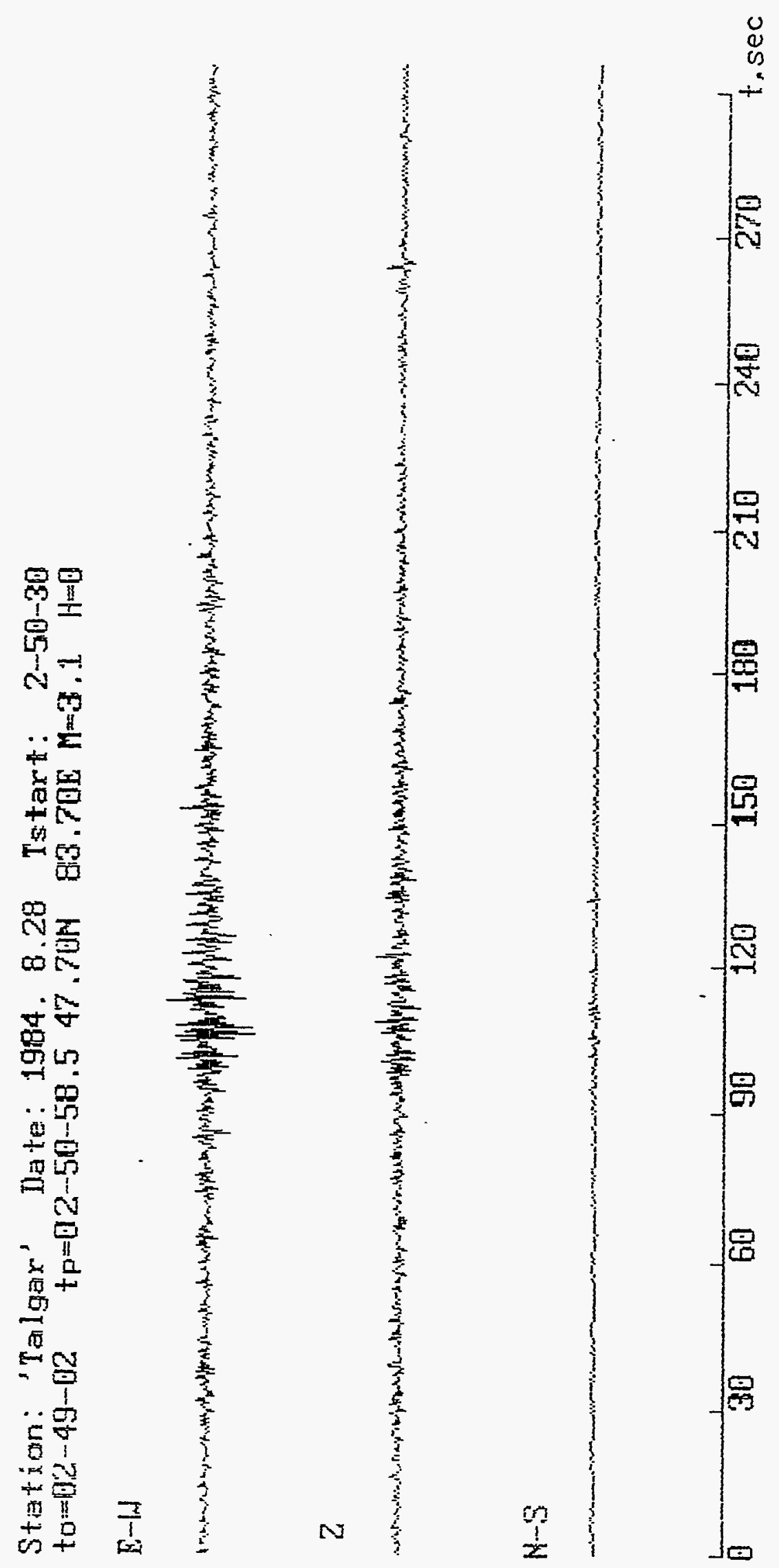


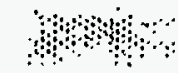

ringygingent?

2

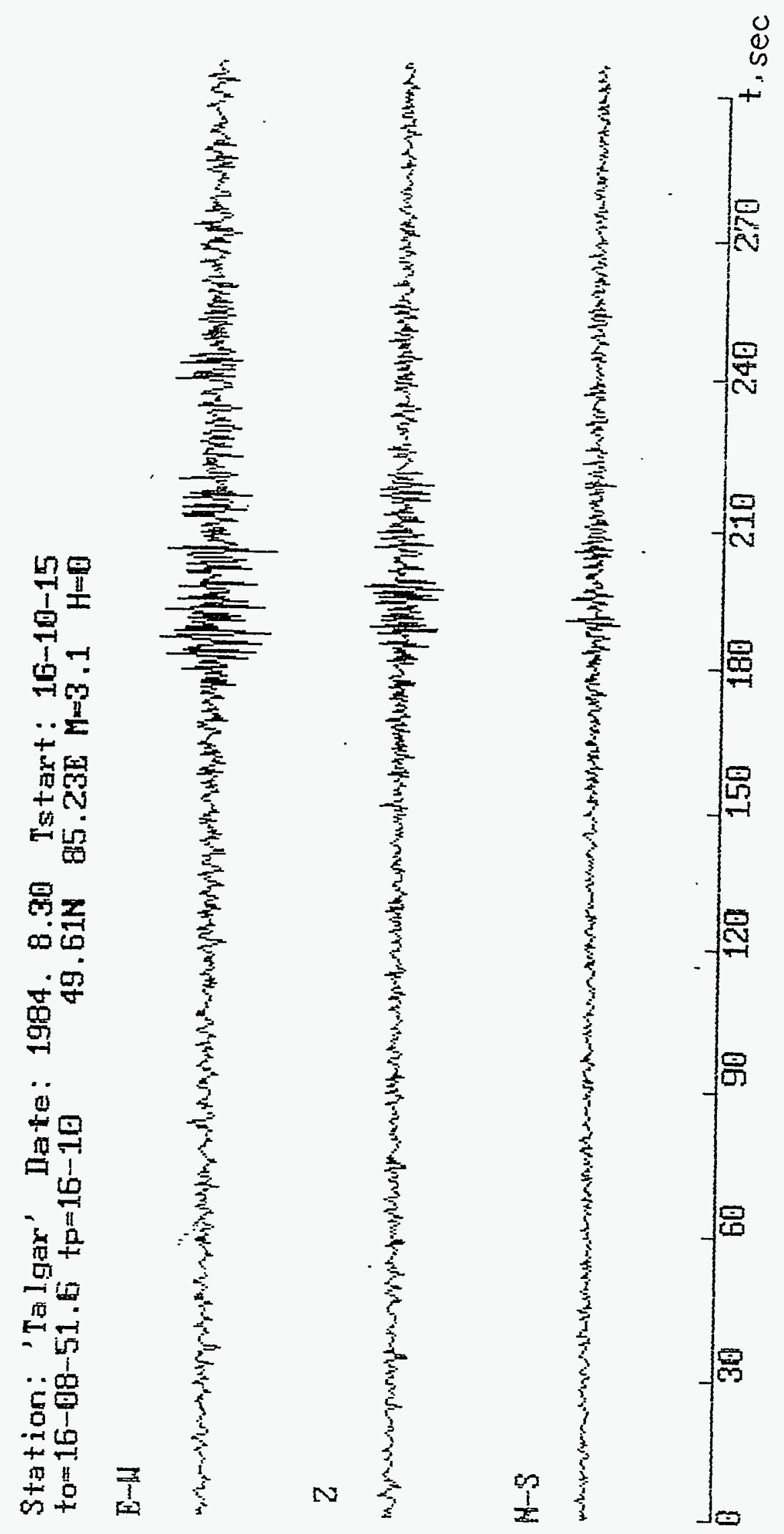




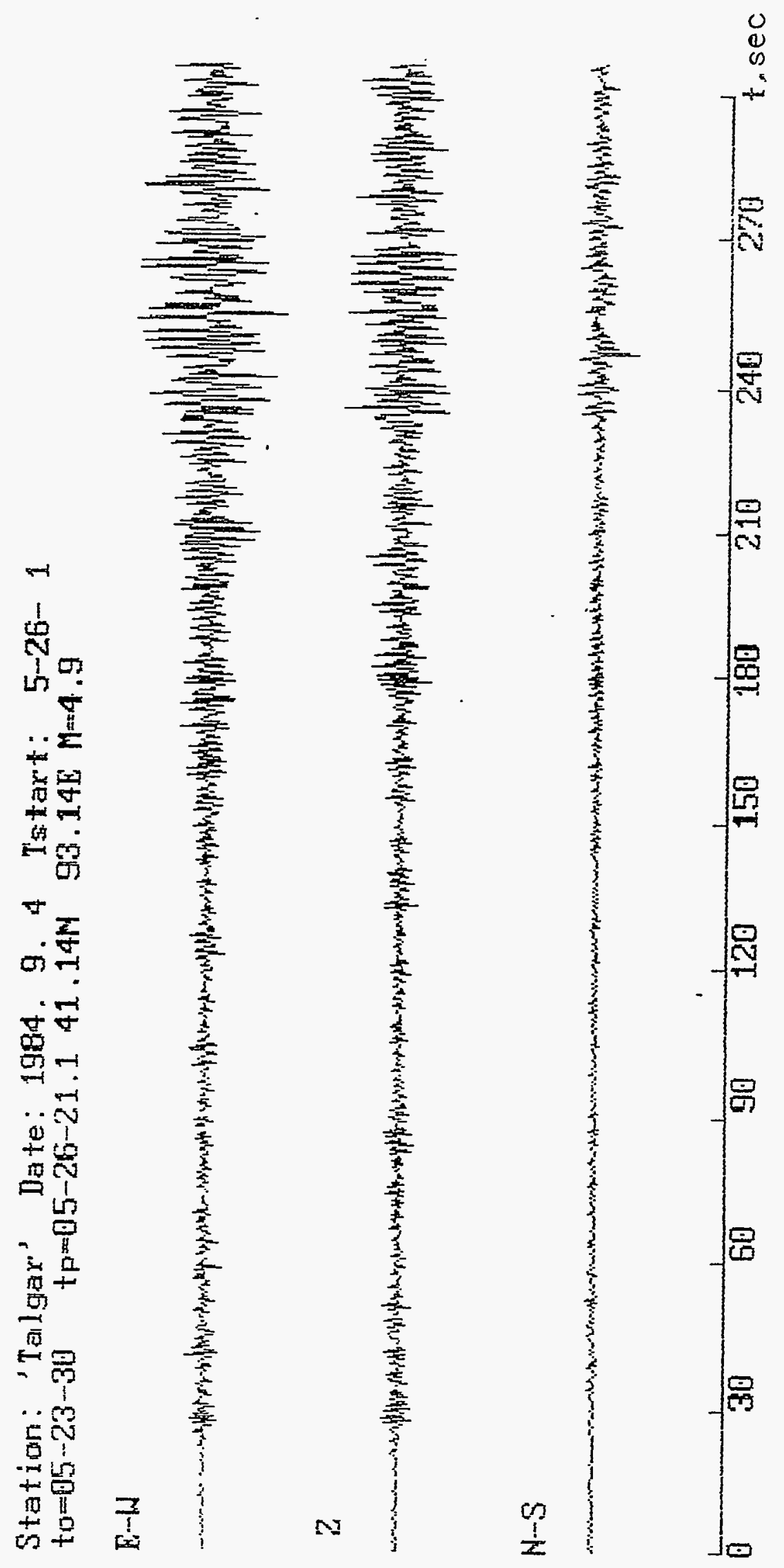



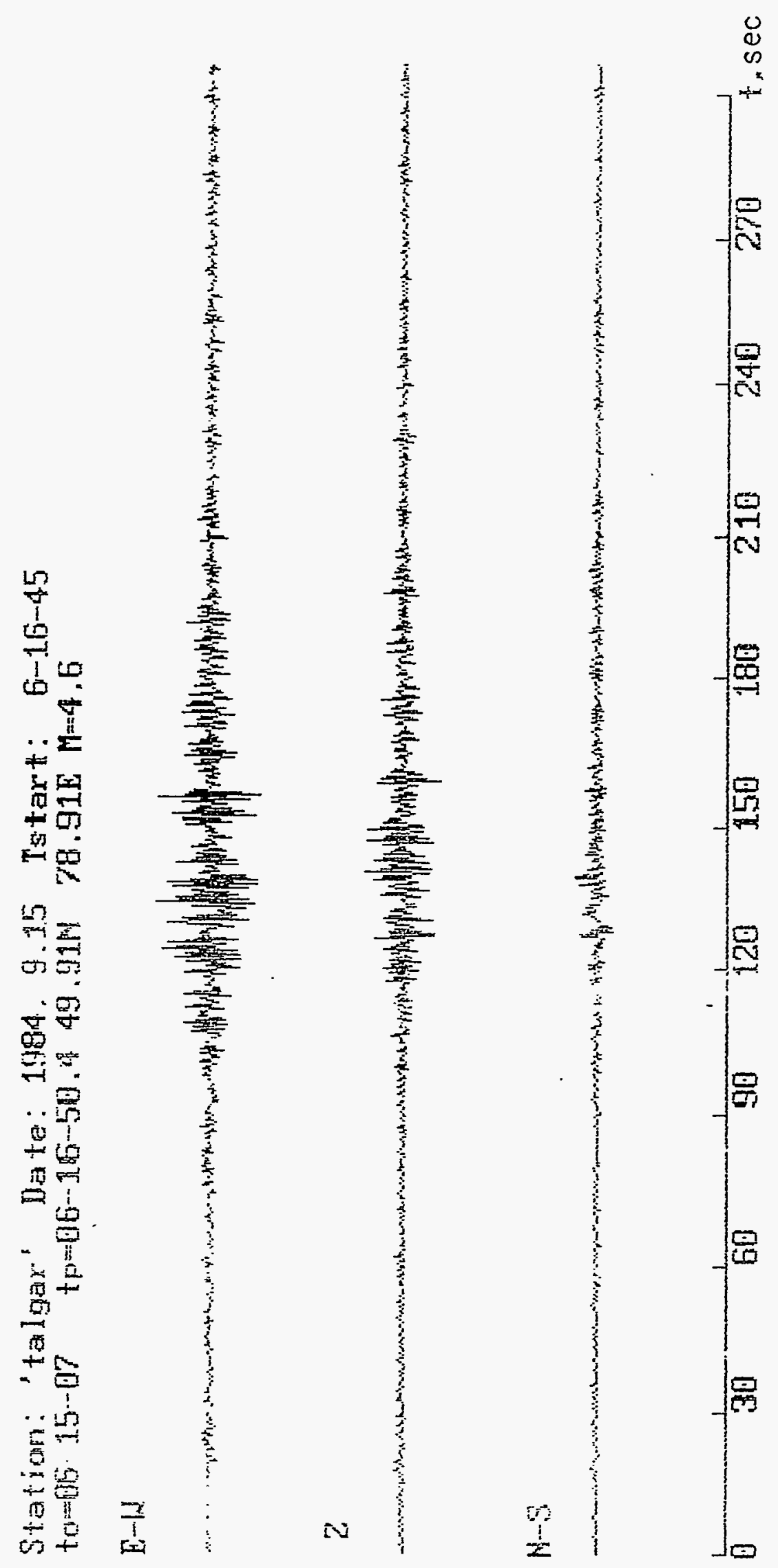


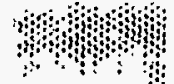

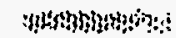

"4:

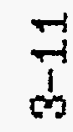

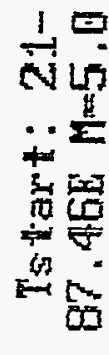

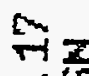

काष

药

단 45

$\therefore 7$

is

0

$-\pi$

is

夏

iv

E

. 1

c

可

点莒
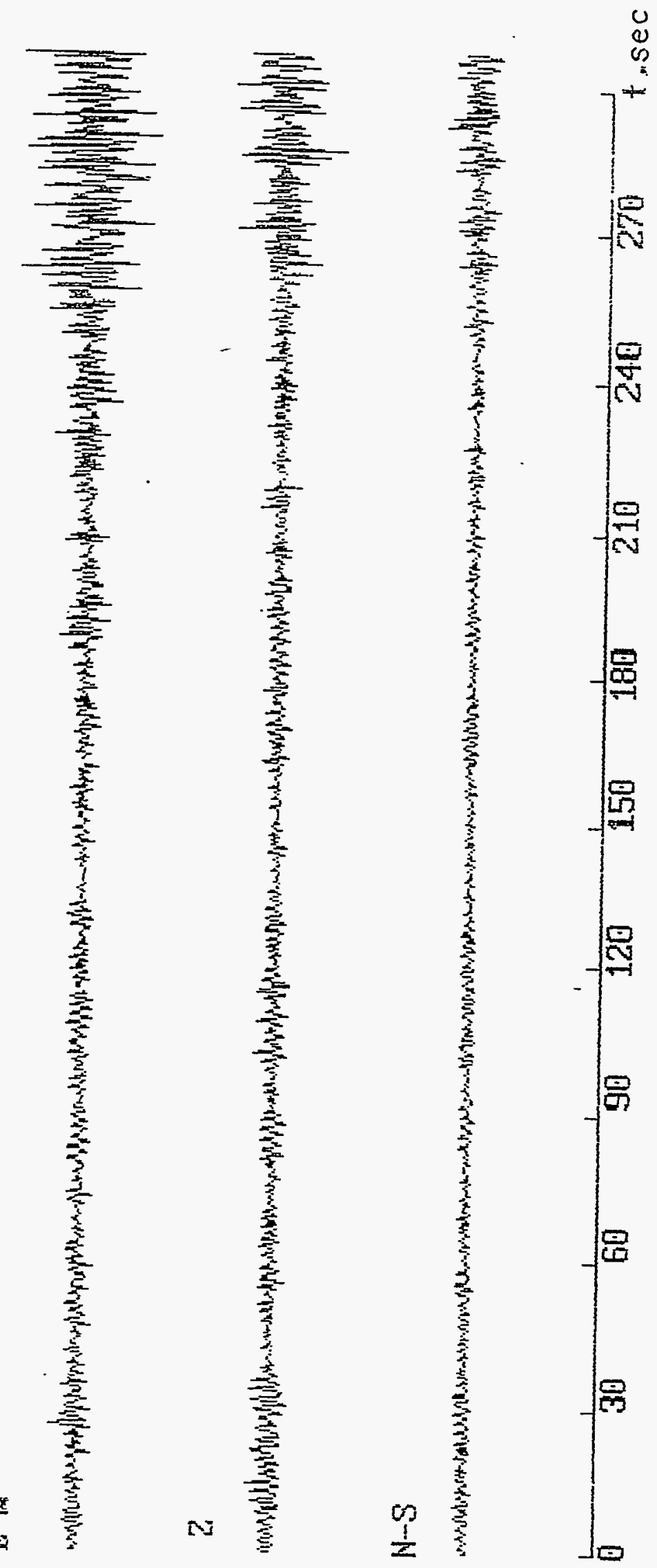


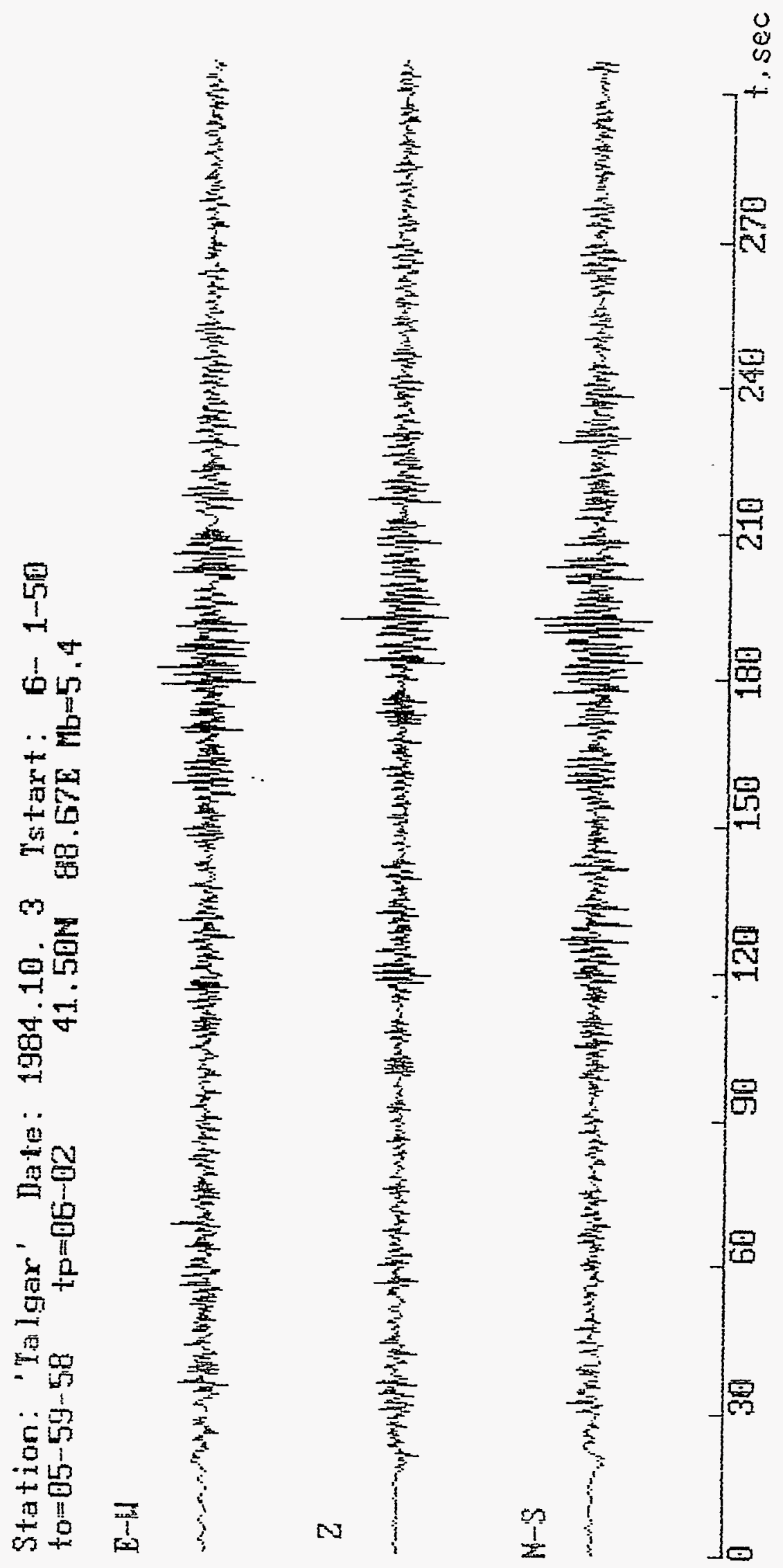




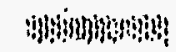

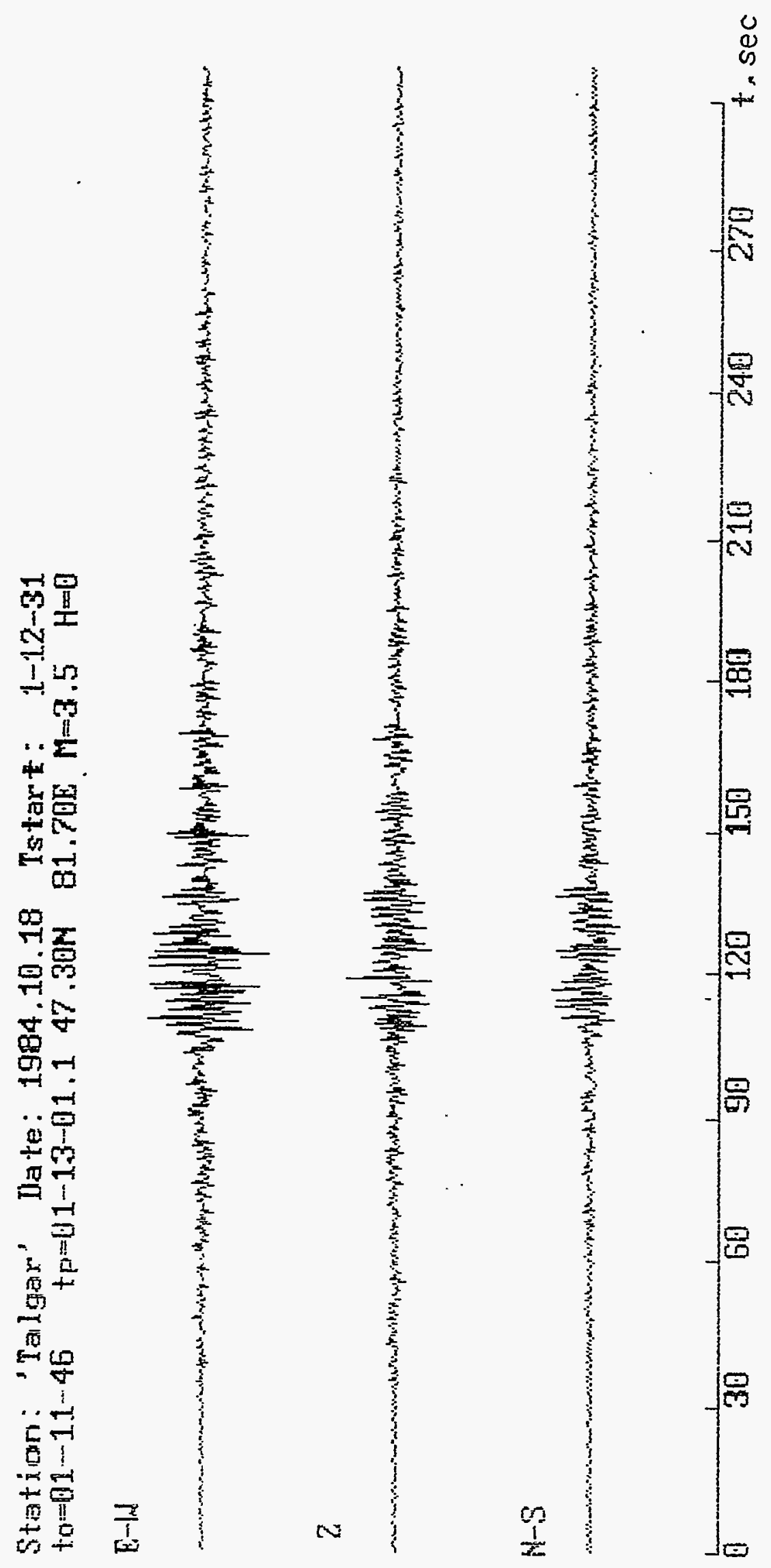



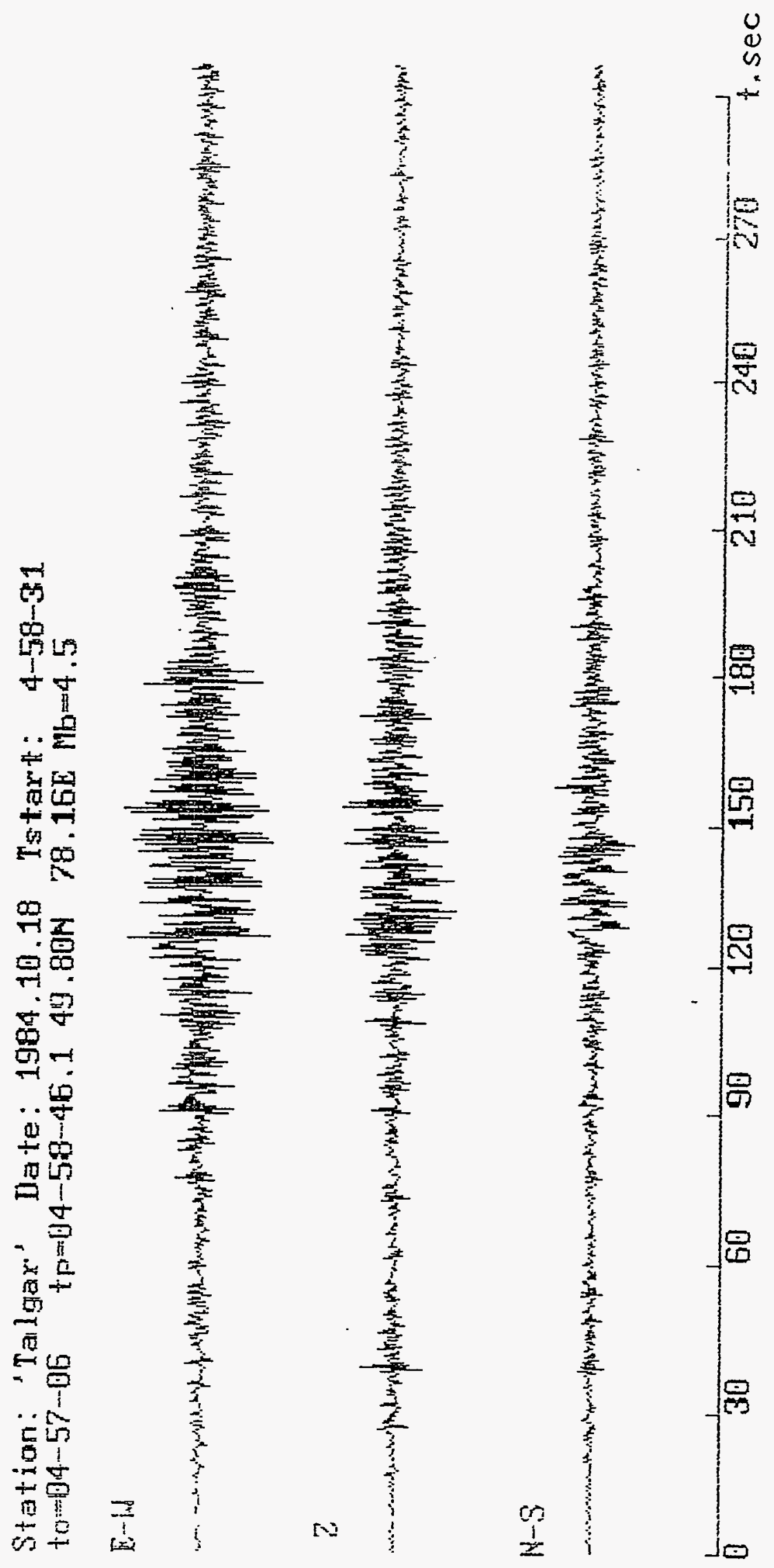
m

mentiming

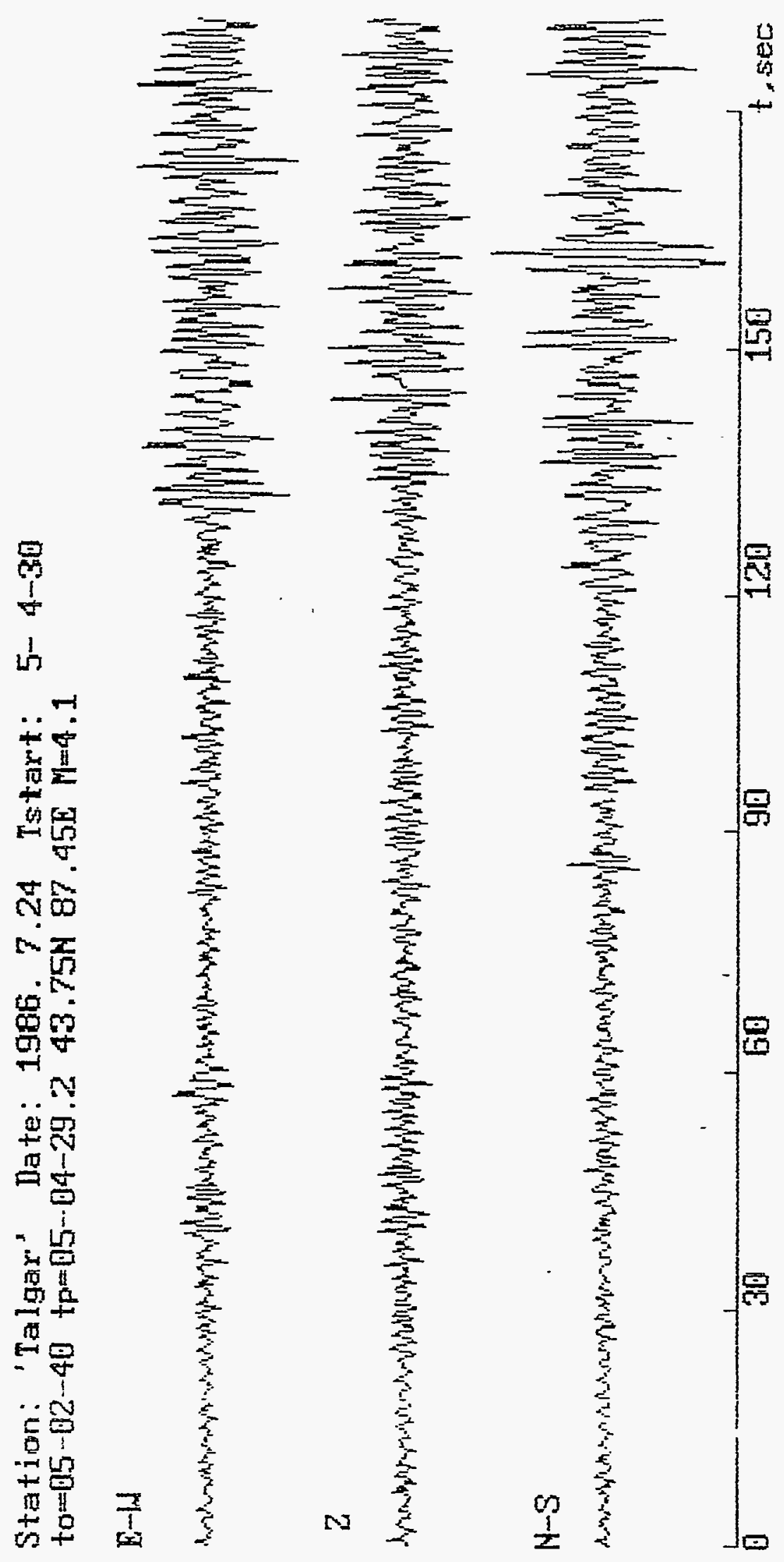




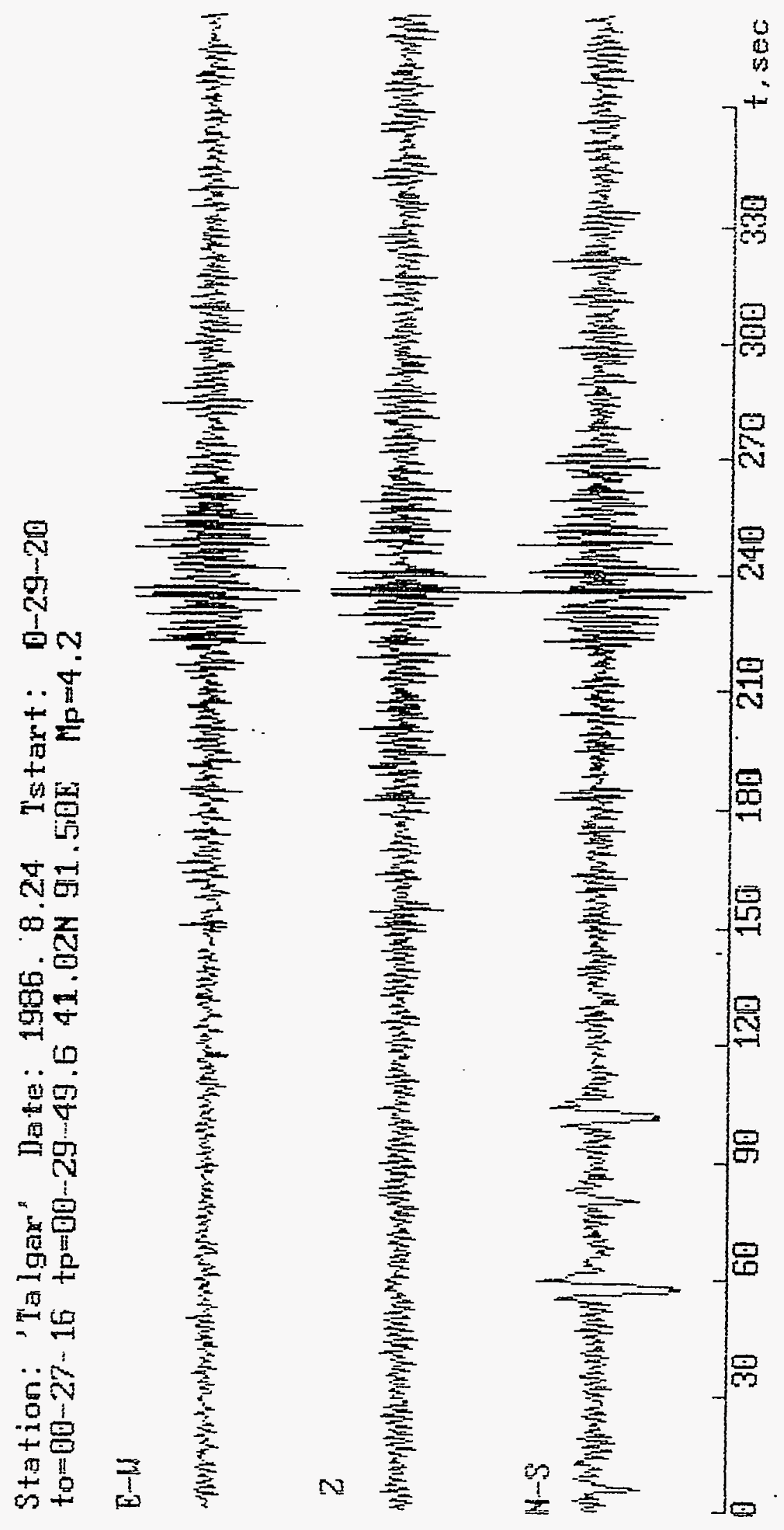


$\because \therefore \because$

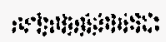

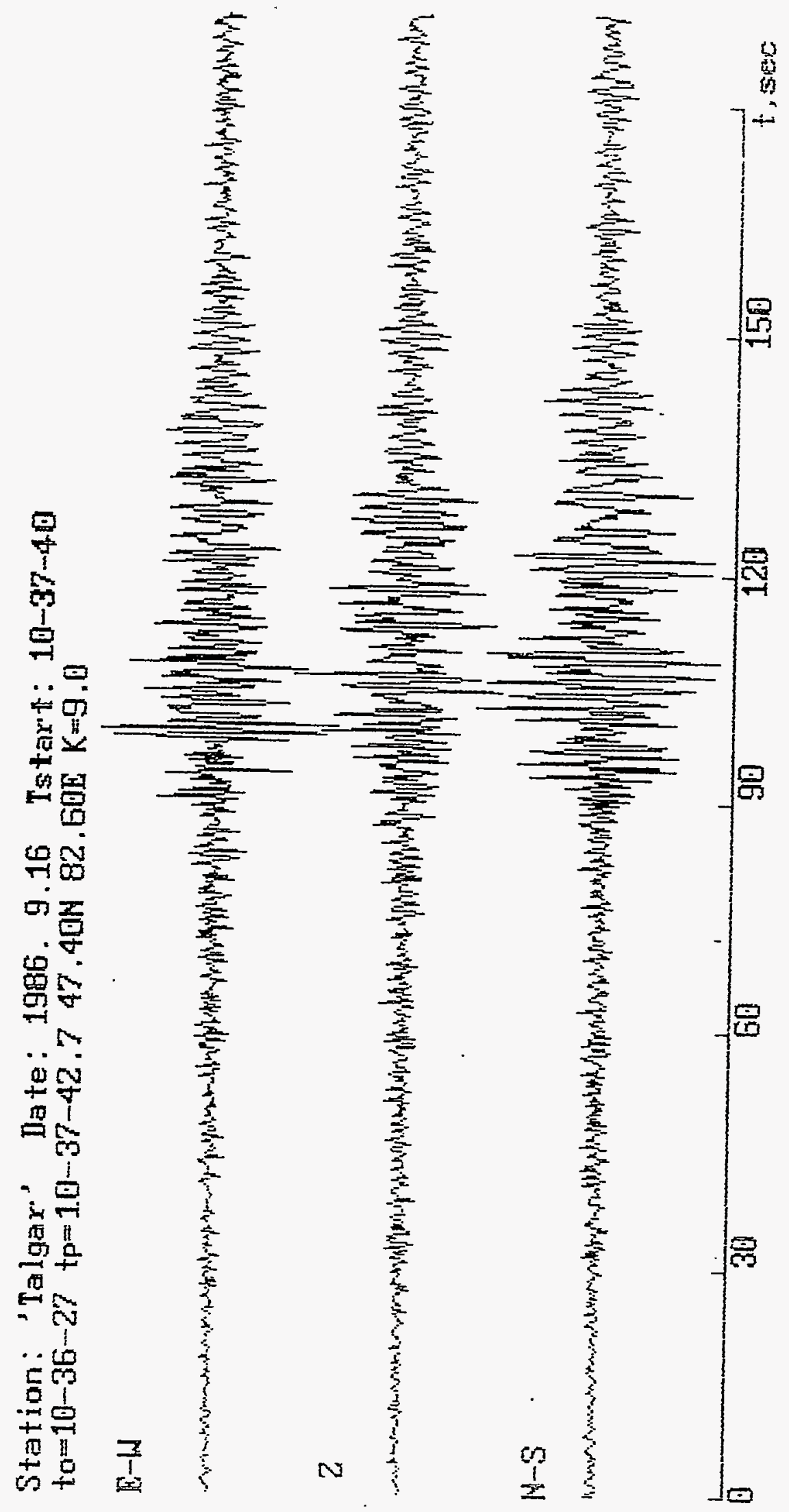




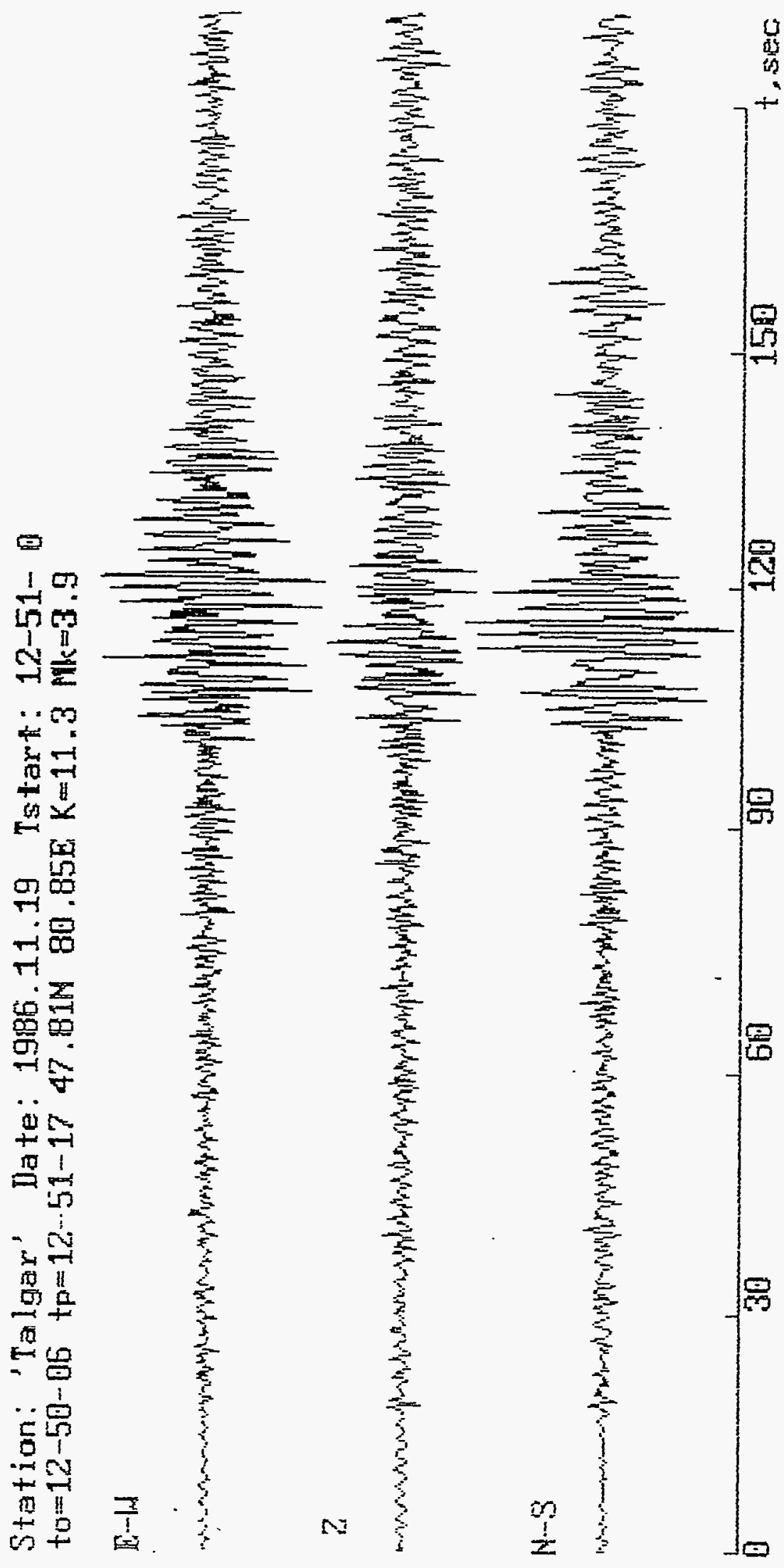




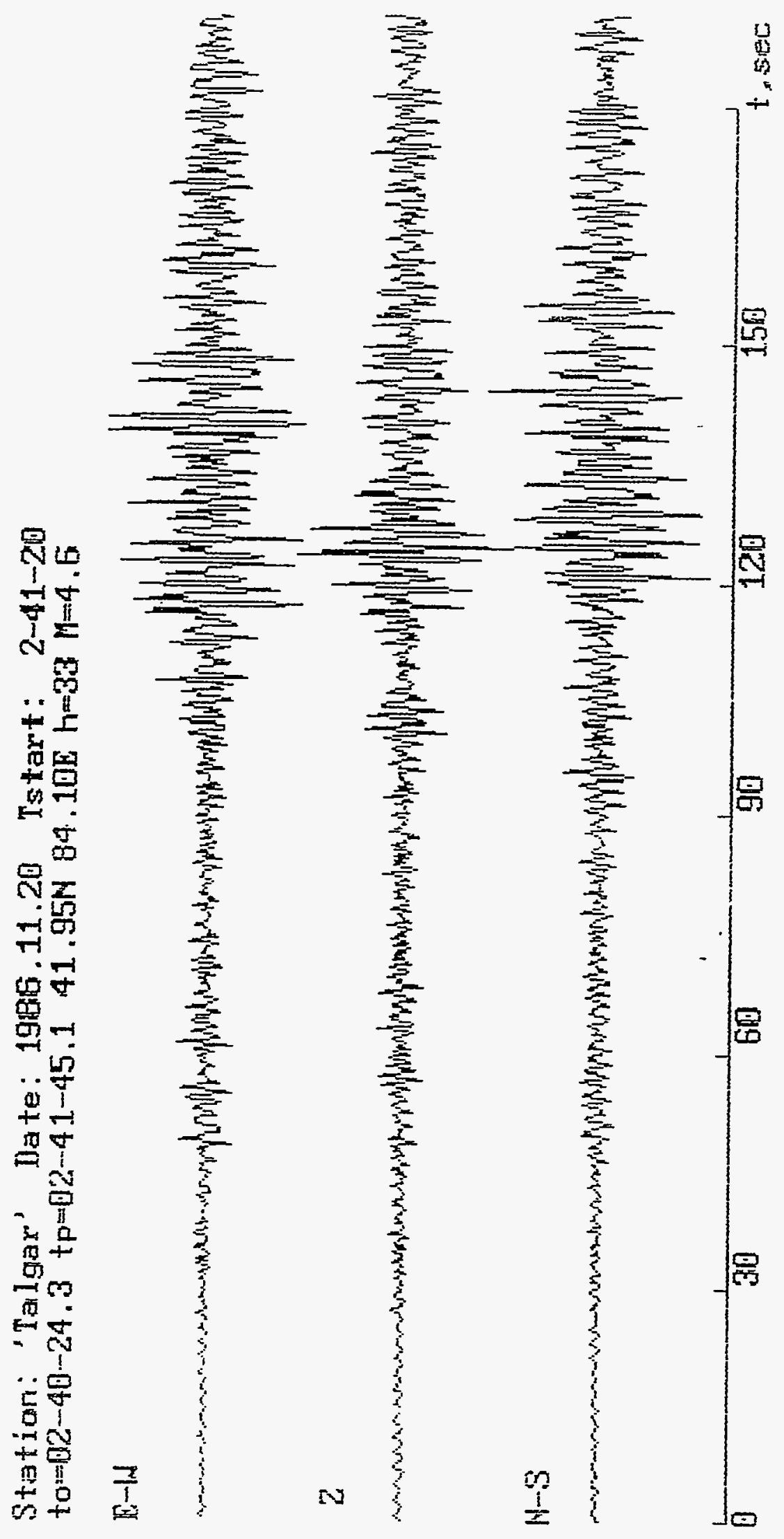




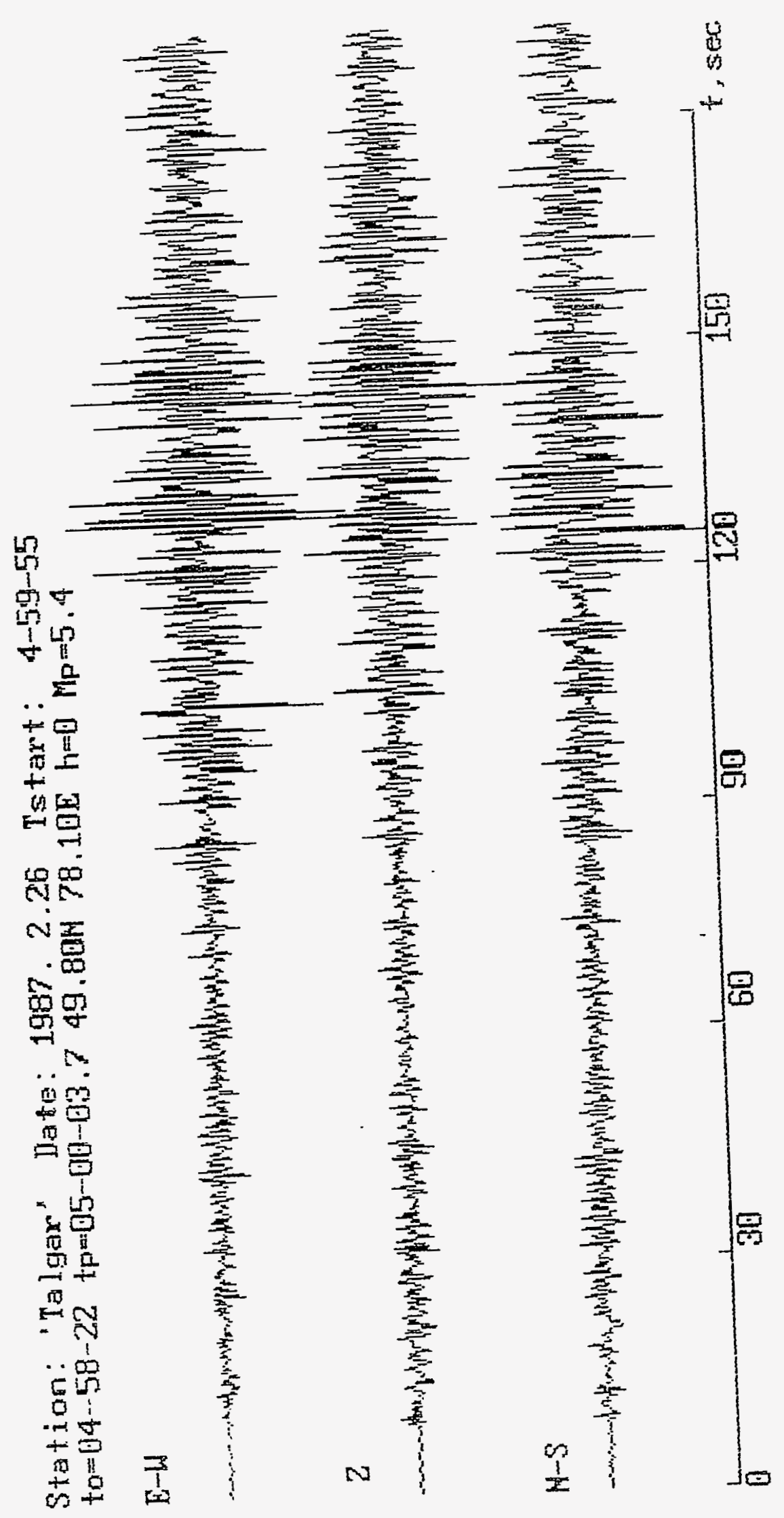


$\because$

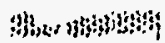

a)

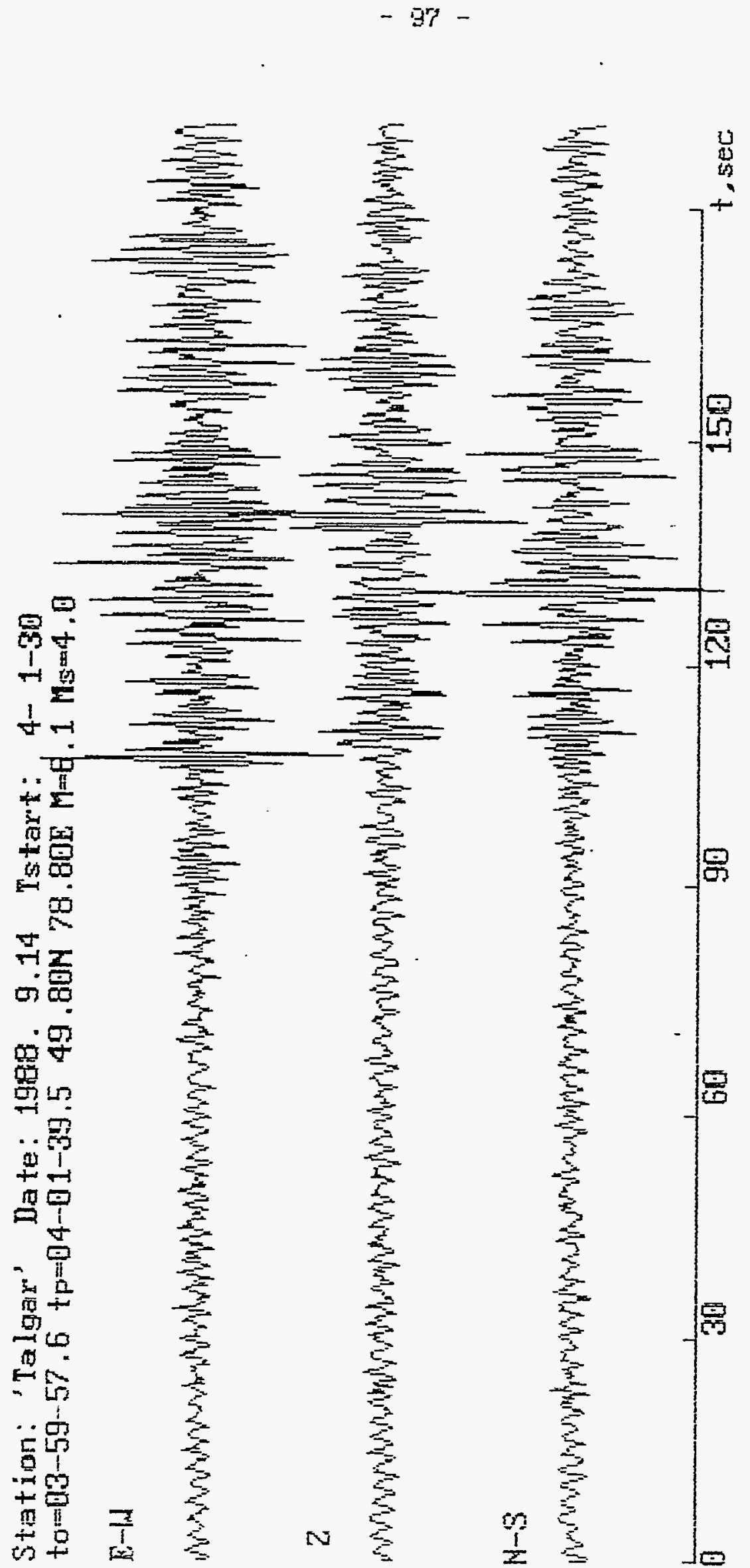




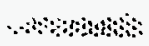
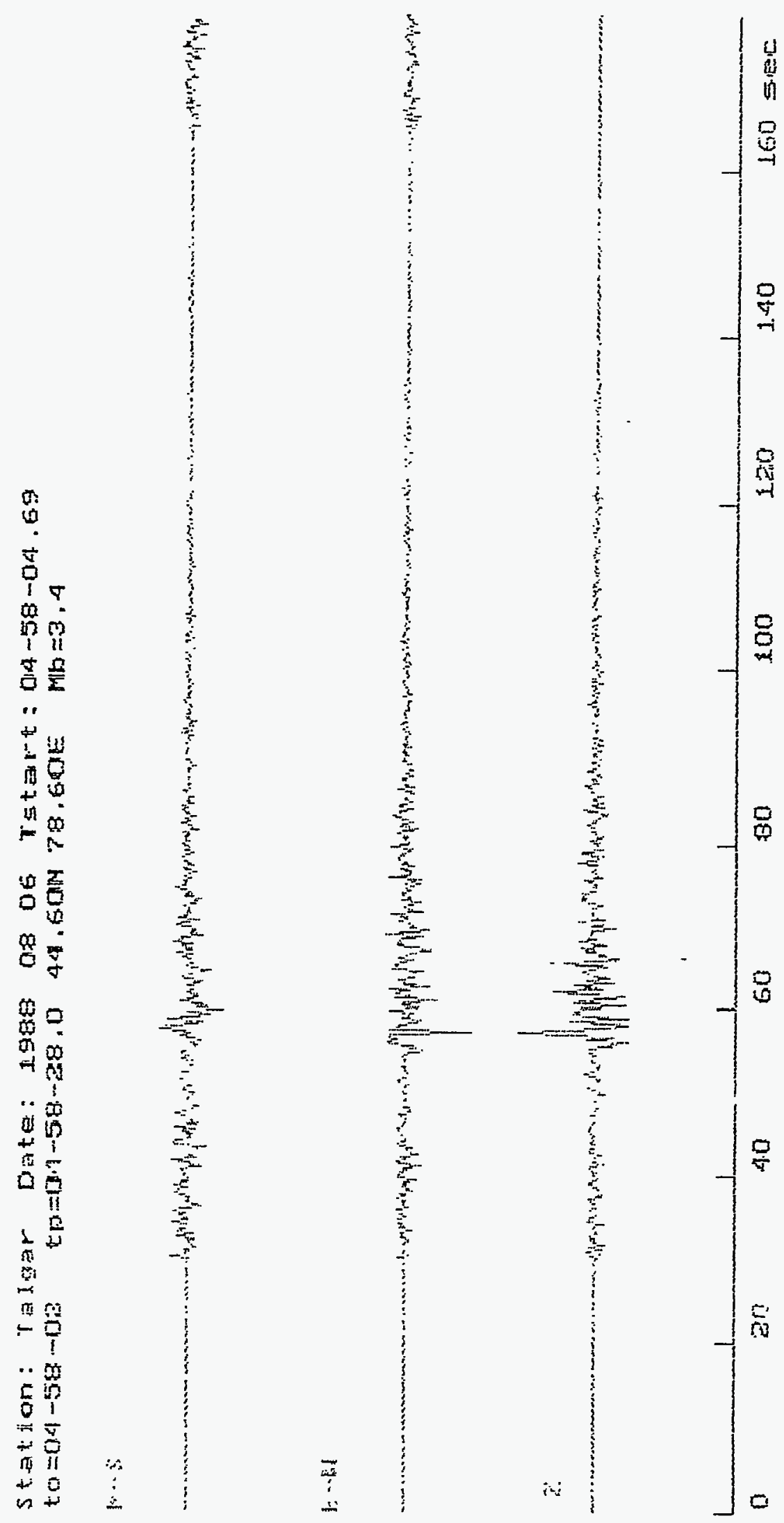
?.
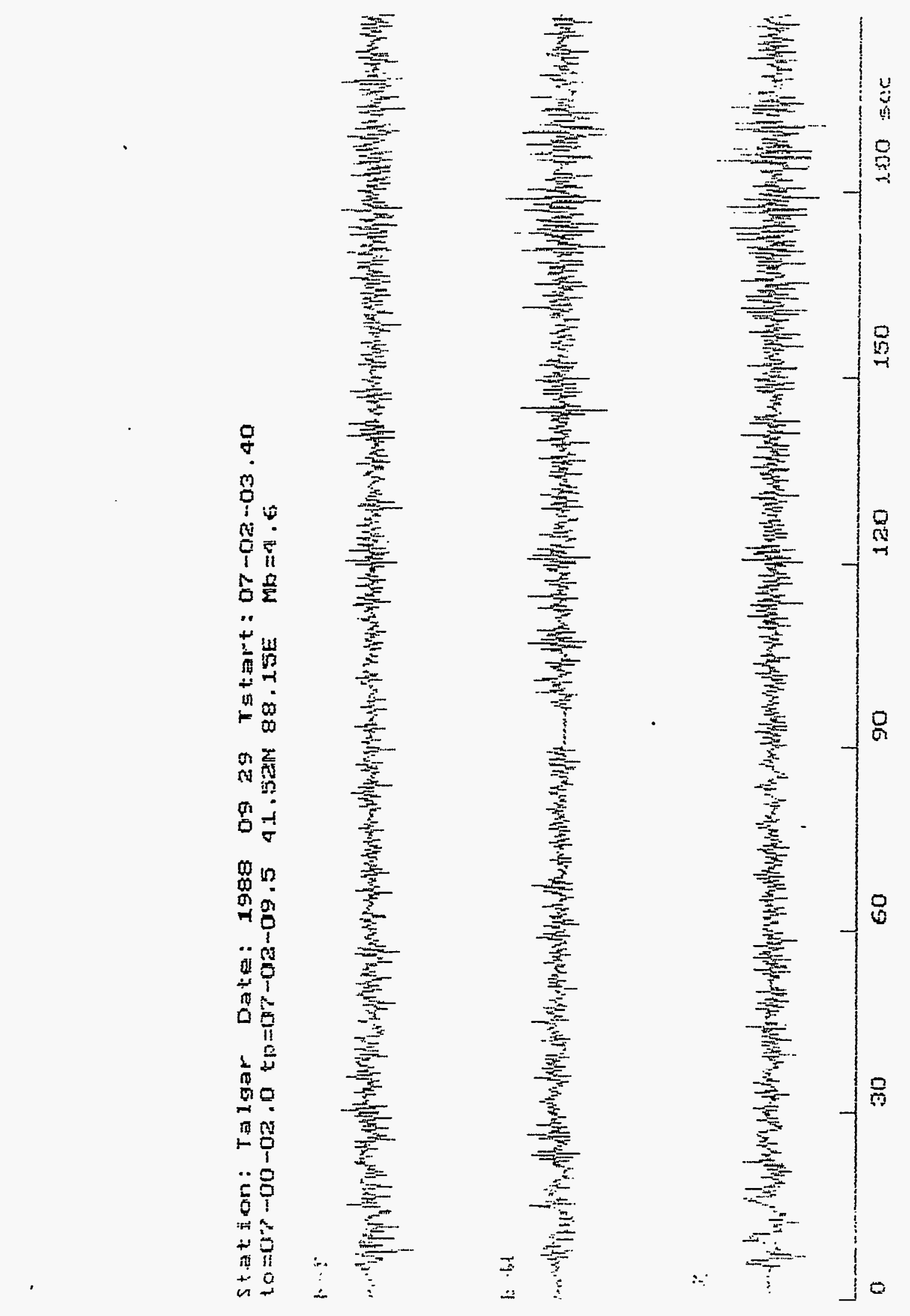

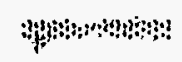



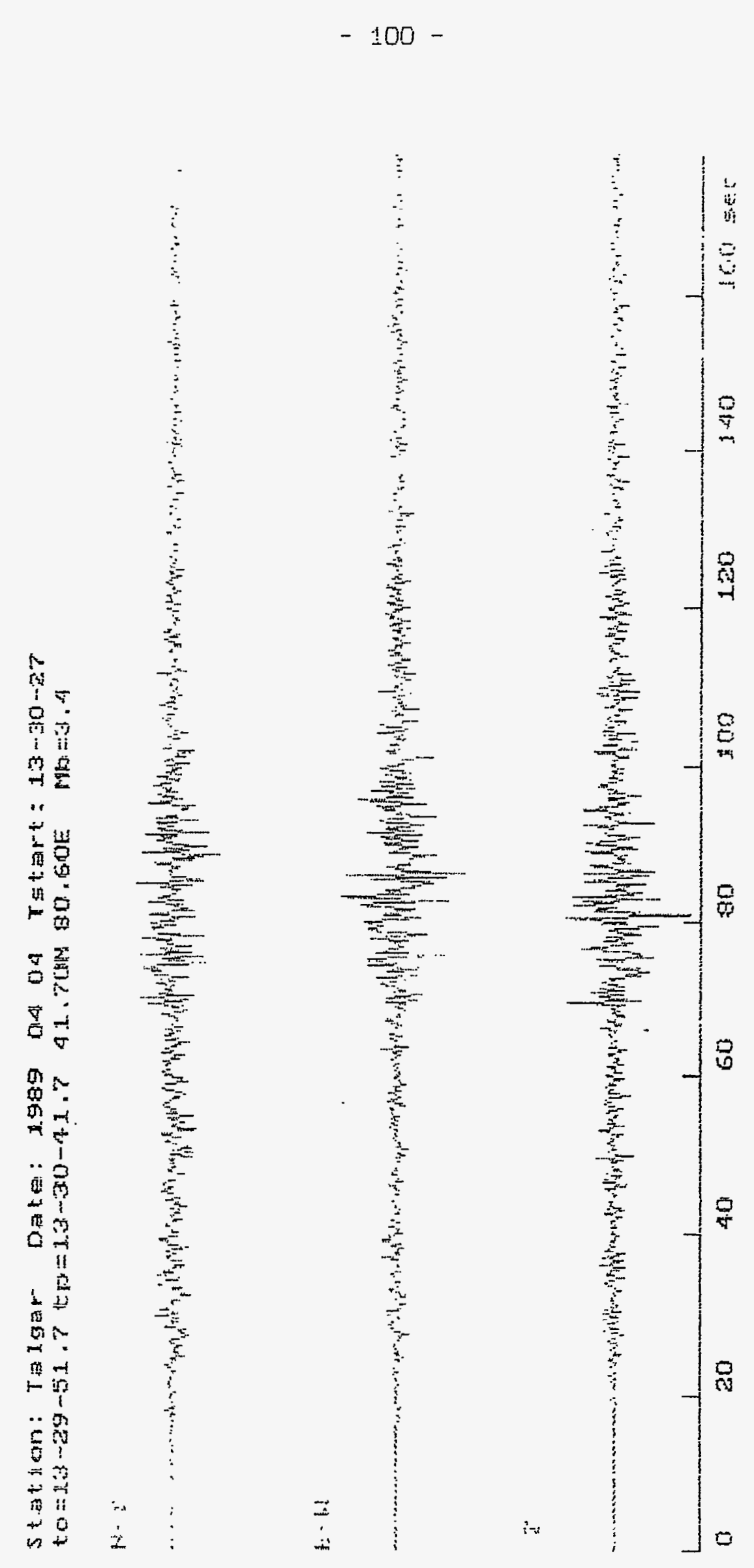

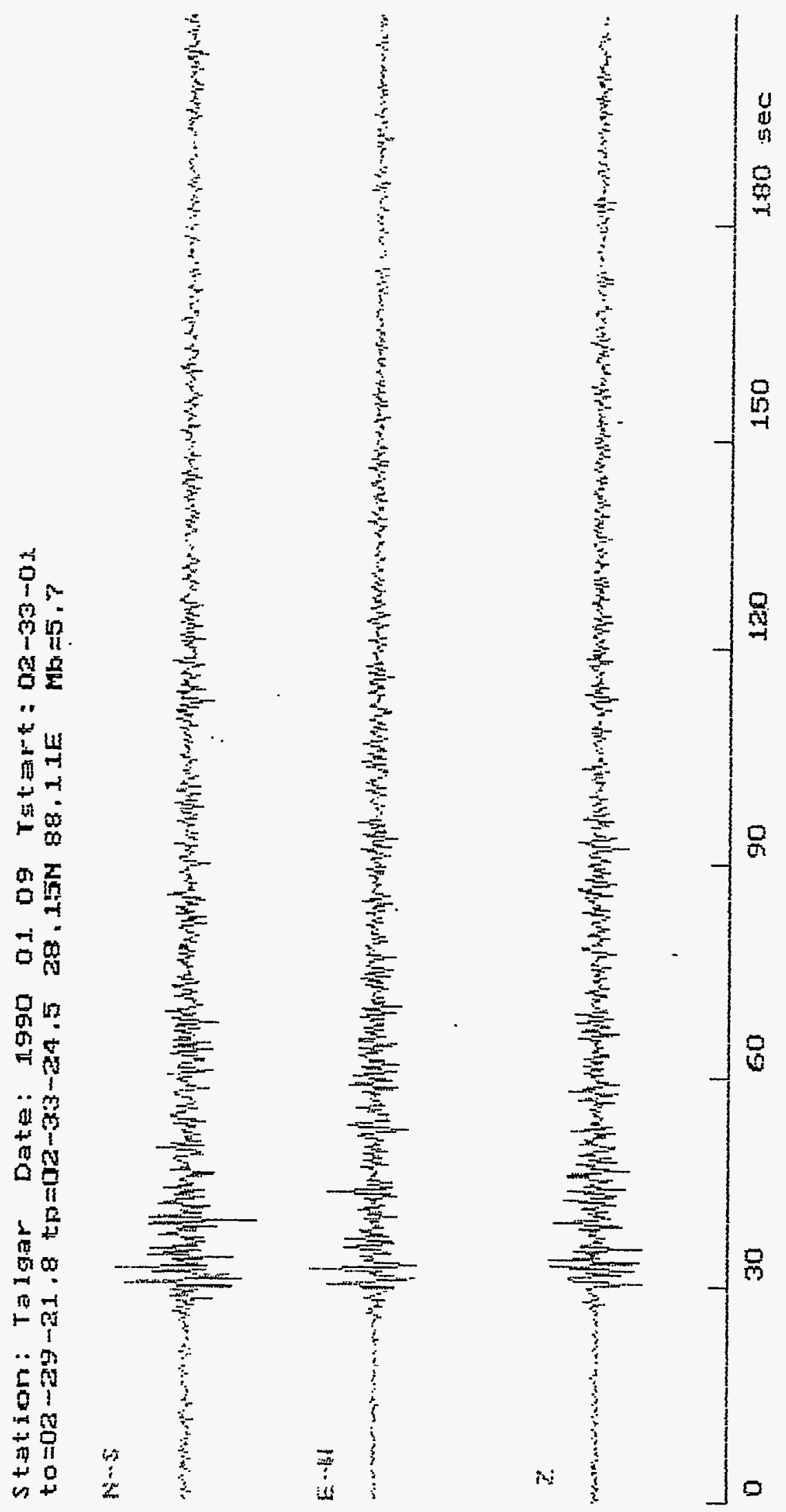


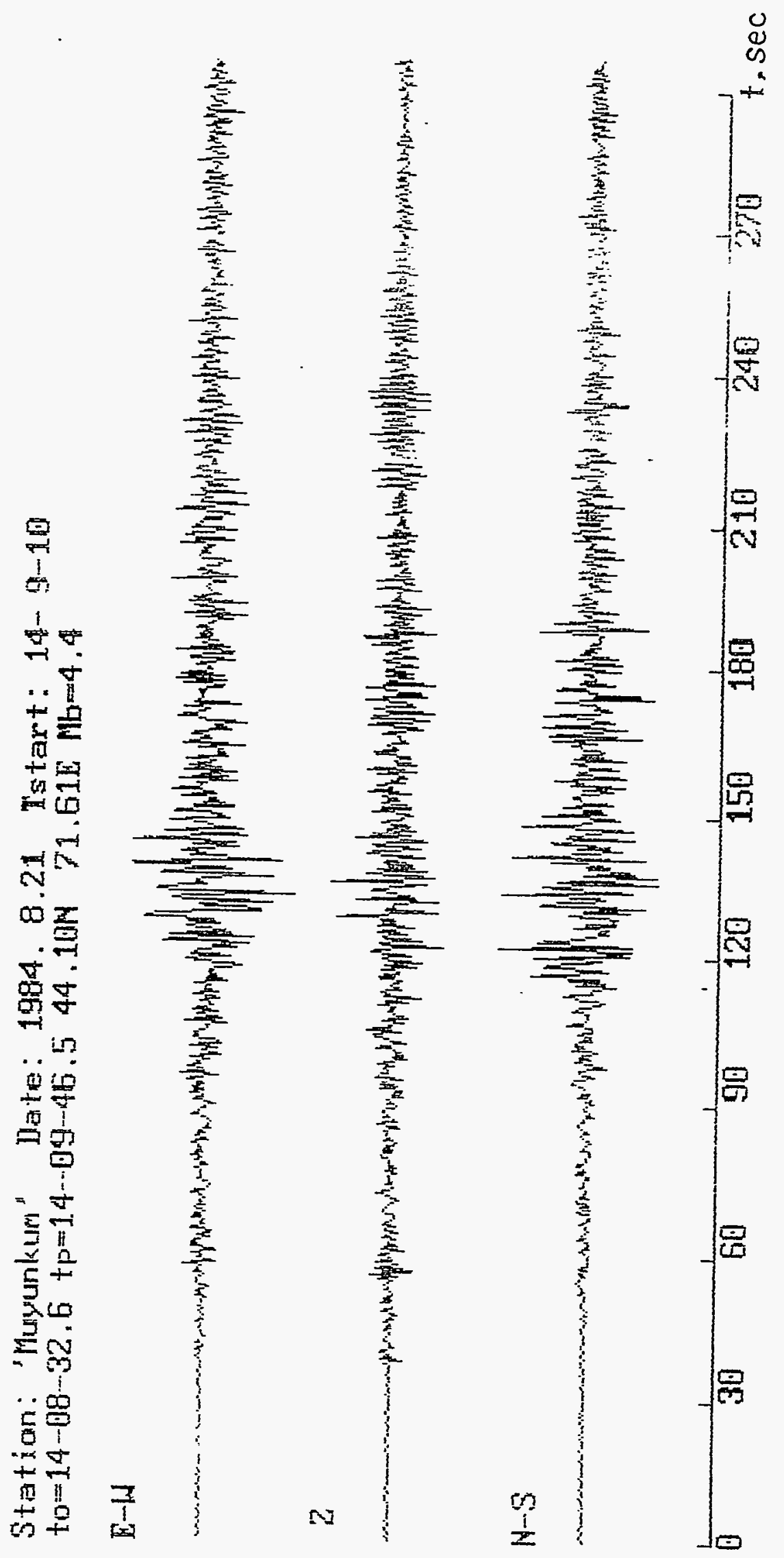



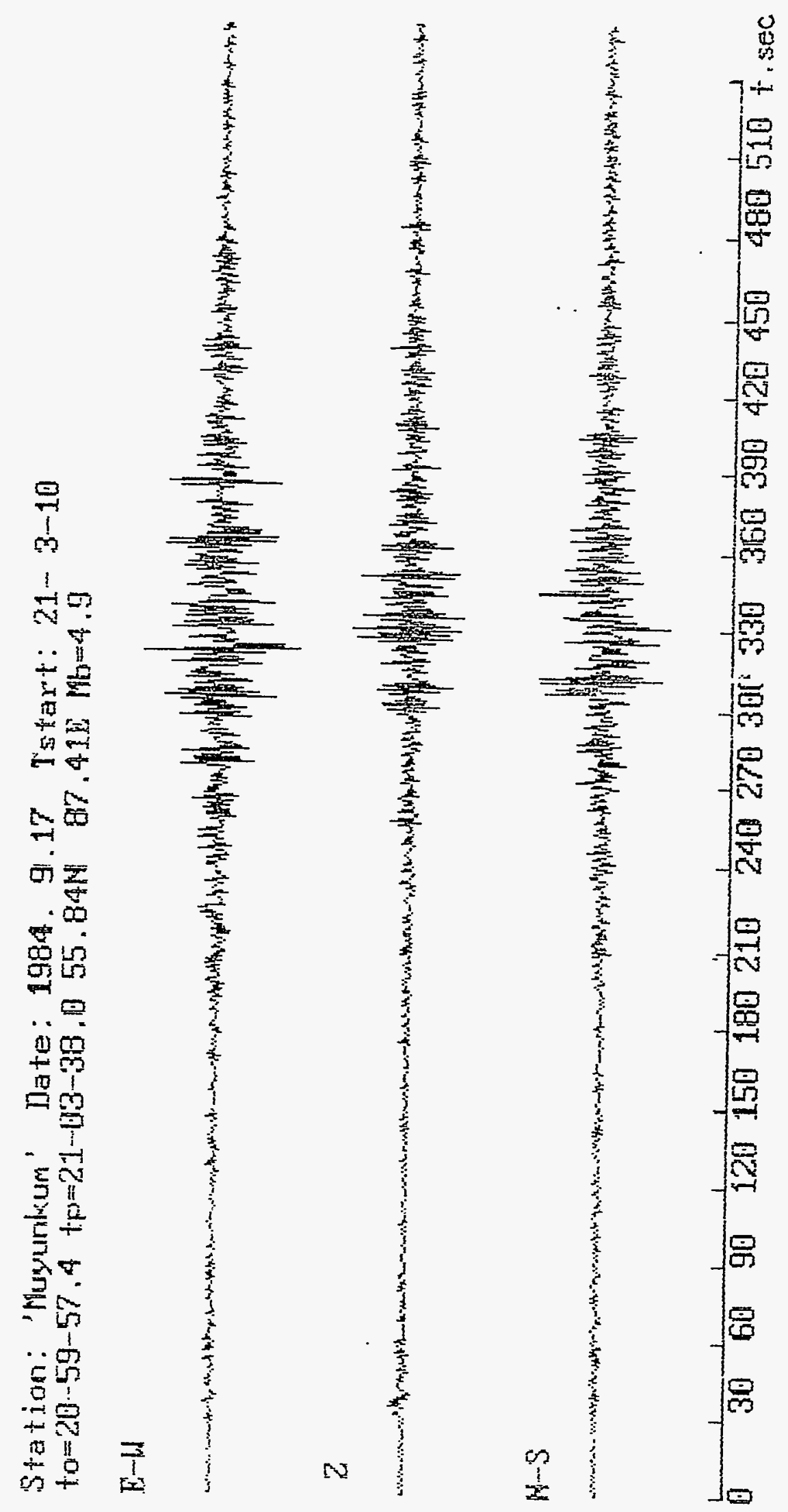
CONCLUSIONS.

In this report, we describe the results of the work on the establishment of the data hase of regional seismic recordings from earthquakes. chemical and nuolear explosions in the former Soviet Union. These data were received either by digitizing the analog records (mainiy), or direotly in digital form using the magnetic reoording system.

The equipment, methods of investigations and primary data processing were described.

The largest number of digital seismograms (55) corresponds to the permanent seismio station Talgar, situated in the North Tien Shan region, to the east of the city of Almaty. More than half of them are the records of underground nuclear explosions and chemical explosions. The UNE have been recorded mainly from the semipalatinsk test. site (at distances of about $700 \mathrm{~km}$ ). In addition, we have recorded seismograms for an UNE from the chinese test site Lop Nor and for an industrial nuclear explosion from west Siberia.

A few records of the chemical explosions were also picked out (two of these have been produced direotly at the Semipalatinsk test site). We have obtained 6 records of crustal earthquakes from the Altai region, close to the Semipalatinsk test site, and 8 records of earthquakes from the west china region, close to the Lop Nor test site. Seismograms of earthquakes from some other regions of 
Eurasia have been also digitized.

in addition, we have included a small number of earthquakes and nuclear explosions seismograms recorded by small arrays of temporary stations which were situated in the southern Kazakhstan region.

z-component seismograms were digitized, with a frequency of digitization in different cases of 20 or $25 \mathrm{~Hz}$ (usually), and also 40 or $100 \mathrm{hz}$. The record duration varies from 180 to 410 seo.

The file struoture was desoribed in detail. All digital seismograms were copied into floppy-disks, which are given to the University together with this report.

It is worth noting, that only a smail part of the data socumulated by the CSE, is included in this report. As mentioned above, the major volume of the data obtained by the CSE is in the form of photographic or usual paper seismograms. Due to this a problem of digitizing this huge information archive is still extrenely important. As a first step we can suggest to digitize records of underground nuclear explosions from the Semipalatinsk and lop wor test sites, and also nearby chemical explosions and earthquakes. The major volume of information, most important for solving the problem of discrimination of nuclear and chemical explosions, and also earthquakes, is obtained by the Talgar and Zerenda stations (northern Kazakhstan, near Eorovoye). These stations have been working continuosiy from 1961 and 1969, respectively. Note, that only one unique station zerenda. which had a magnification about 1 million at a 
narrow-band channel, centered at $1 \mathrm{~Hz}$, have recorded for this time period many hundreds of relativeiy weak expiosions, either nuclear or chemicai, with magnitudes mat $=3.0-4.0$ and ever less.

To solve this problem it is necessary to have corresponding equipment. - computers, scanners as weil as specialized software.

*This work was performed under the auspices of the U.S. Department of Energy by Lawrence Livermore Nationai Laboratory under contract No. W-7405-Eng-48. 
REFERENEES.

Aranovich 2.I., Kazak B.N. Negrebetzkiy S.A. et. EI. (1987). Frogram-controlled seismio complex puSK-1. In: Devices and methods of the earthquakes registration. Seisnic devices. Issue 19. Moscow : Nauka Fublishing House, p.17-21 (ir Fussiari)

Erulev Yu.V. Krylov G.G., Nersesov 1.L. et al. (1980). Apparatus for regional seismio investigations. In: Instrumental means for the seismic observations. Seismio devices, Issue 13. Moscow: Nauka Fublishing House, p.138-158 (in Russian).

Dieital measuring device UTI-1. A technical description (1986). Thilisi (in Russian).

Negrebetzkiy S.A. Turetzkiy I.M. (1980). Device for providing a format. "floating point "in the digital seismic system. In: Instrumental means of the seismic observations. Seismic devices, Issue 13. Moscow: Nauka Fublishing House, p.122-120 (in Fussian).

Nersesov I.L., Kaazik F.E., Rakhmatullin M.Kh., Tregub F.S. (1900). [n a possibility of searching the gas deposits using speotral ratios of microseismio noise amplitudes. DAN SSSR, $\because .312, \mathrm{~N} 5$ (in Fussian).

Radiotelemetric analos seismic system FTS-AN. A technical desoription (19g0). Alma-Ata (in Fussian). 